\title{
Paying for Disasters
}

\author{
Shelley Ross Saxer*
}

INTRODUCTION

Below the steep Santa Ynez mountain range in Santa Barbara County lays the unincorporated town of Montecito. The town is located on the alluvial fan created by sediment and sandstone boulders from the mountain range above. The Thomas Fire burned through approximately 282,000 acres from Santa Paula through Ventura and to the mountains above Santa Barbara and Montecito in the fall of 2017. ${ }^{1}$ Southern California Edison admitted that its equipment likely ignited the Thomas Fire. ${ }^{2}$ Unfortunately, the greatest devastation for the small town of Montecito occurred on the night of January 9, 2018, when heavy rainfall caused catastrophic erosion of the burned slopes and debris swept through the sleeping community killing 23 people and demolishing 130 homes. $^{3}$

Who should pay for this disaster? The impacted individuals, families, and businesses sued Edison because its equipment likely sparked the fire that burned the slopes, which caused the rain erosion and killed the people who lived in the houses built in the floodplain. ${ }^{4}$ In return, Edison sued Santa Barbara County, alleging that county officials and planners had allowed increasing development and the building of bridges in designated flood zones, which contributed to the debris flow. ${ }^{5}$

\footnotetext{
* Laure Sudreau Endowed Chair in Law, Pepperdine University School of Law. The author is indebted to many who have reviewed and commented on this Article in its earliest and latest edition, including Nestor Davidson, Tim Duane, Alexandra Klass, J.B. Ruhl, Sarah Schindler, and Elise Foster (U.S. Department of Agriculture). The author is also grateful to Hanna Jolkovsky and Enoch Cheung for their editing skills in reviewing this Article. Any mistakes belong to the author.

1. News Release, Southern Cal. Edison Int'l, SCE Provides an Update on the Circumstances Pertaining to the 2017 Thomas Fire (Oct. 30, 2018), https://newsroom.edison.com/releases/sceprovides-an-update-on-the-circumstances-pertaining-to-the-2017-thomas-fire [https://perma.cc/5MU 2-NEZB].

2. Id.

3. Joe Mozingo, Edison Sues Santa Barbara County Over Last Year's Deadly Mudslides, L.A. TIMES (Jan. 18, 2019， 4:45 PM), https://www.latimes.com/local/california/la-me-montecitomudslide-lawsuit-20190118-story.html [https://perma.cc/7J3W-RSWD].

4. Id.

5. Id.
} 
Edison also sued the California Department of Transportation for the freeway bridges, the flood control district for the debris-filled basins, the City of Santa Barbara for allowing commercial development in a city zone adjacent to Montecito, and the Montecito Water District for a broken water main that contributed to the flooding. ${ }^{6}$

Rain from Hurricane Florence, which struck the Carolinas in September 2018, killed more than fifty people ${ }^{7}$ and caused massive flooding, waterlocking cities throughout the region. ${ }^{8}$ State officials in South Carolina ordered National Guard troops and transportation workers to erect a barrier in the inland community of Conway to protect the gateway route into Myrtle Beach and tourist towns from flooding while potentially redirecting waters into local neighborhoods. ${ }^{9}$ While local officials in Conway hired a lawyer to block the barrier by seeking injunctive relief, the Myrtle Beach mayor supported building a barrier to protect beach businesses that depend on September visitors and discounted Conway's fears of community flooding. ${ }^{10}$ Conway resident Georgia Johnson protested that the officials were "going to block off where nature wants to flow," and said officials should "do things for the good of all, not some." 11 Her husband Lex, who trained as a mechanical engineer, worried that the barrier would only make the flooding worse. ${ }^{12}$ Conway officials pointed to the aftermath of Hurricane Harvey in Houston the prior year, when residents filed suit against the U.S. Army Corps of Engineers alleging a taking of their properties after the agency released excess water from reservoirs and flooded their neighborhoods. ${ }^{13}$

The government may take property for public use by condemning it for redevelopment or infrastructure, or restricting a property owner's rights by burdensome regulation. It may also give property rights by granting broadcasting or easement rights to cable companies, eliminating

6. Id.

7. Gabriella Borter, Hurricane Florence Death Toll Rises to 51, REUTERS (Oct. 2, 2018, 1:39 $\mathrm{PM}$ ), https://www.reuters.com/article/us-storm-florence/hurricane-florence-death-toll-rises-to-51-id USKCN1MC2JJ [https://perma.cc/7J9B-V8DU].

8. Florence Gone but Its Flooding a Crisis in Parts of North Carolina - Live Updates, CBS NEwS, https://www.cbsnews.com/live-news/hurricane-florence-aftermath-weather-flooding-poweroutage-death-toll-fema-latest-forecast-live/ [https://perma.cc/2CUH-EGSP] (last updated Sept. 19, 2018, 1:38 AM).

9. Molly Hennessy-Fiske, South Carolina Officials Clash Over Flood Barrier, L.A. TIMES (Sept. 16, 2018, 8:05 PM), https://www.latimes.com/nation/la-na-south-carolina-river-barrier20180916-story.html [https://perma.cc/3DRR-VG8C].

10. Id.

11. Id.

12. Id.

13. Id. 
development restrictions on wetlands, or building a park in a residential area. ${ }^{14}$ Similarly, the effects of disasters and climate change will be uneven, with some areas benefitting from longer growing seasons and temperate weather, and other areas fighting drought, violent weather episodes, and sea level rises. ${ }^{15}$ Just as there are winners and losers when the government or a private entity takes private property for a public use, there are both winners and losers from the effects of disasters and climate change.

Flooding cases in particular illustrate how the benefits from government actions ("givings") may offset or defeat takings claims. ${ }^{16}$ Even though a government project for flood control may cause damage to a private landowner, if the project is beneficial overall because it reduces general flood dangers, the landowner claiming compensation for a taking would receive a windfall. ${ }^{17}$ The government has provided benefits to flood claimants over the years by providing "assistance with subsidies and other measures to promote agriculture and urban development in the floodplain, and to protect vulnerable floodplain land by constructing levees, terraces, and other devices to hold water and protect against soil erosion." 18

Alternatively, tort law could address "government actions involving some risk of a potentially foreseeable, yet diffuse, impact," such as flooding cases when government projects have provided landowners with more benefits than losses, but "the floodwaters exceed the capabilities of those projects." 19 In turn, takings claims could address "purposeful appropriations for public benefit, undertaken with intent or substantial certainty of the consequence." ${ }^{20}$ By distinguishing these claims, the

14. See Abraham Bell \& Gideon Parchomovsky, Givings, 111 YALE L.J. 547, 550-51 (2001) (presenting the concept of "givings" as the counterpoint to "takings" law).

15. J.B. Ruhl, The Political Economy of Climate Change Winners, 97 MINN. L. REV. 206, 20708 (2012).

16. Sandra B. Zellmer, Takings, Torts, and Background Principles, 52 WAKE FOREST L. REV. 193, 237 (2017).

17. Id. (citing United States v. Sponenbarger, 308 U.S. 256, 266-67 (1939)) ("In United States v. Sponenbarger, the Supreme Court explained, '[A] broad flood control program does not involve a taking merely because it will result in an increase in the volume or velocity of otherwise inevitably destructive floods, where the program measured in its entirety greatly reduces the general flood hazards, and actually is beneficial to a particular tract of land." (quoting Sponenbarger, 308 U.S. at 266)); see also Bartz v. United States, 633 F.2d 571, 578 (Ct. Cl. 1980) (finding "the Fifth Amendment does not make the government an insurer against all damages from floods" where a flood-control project confers benefits that greatly outweigh damages).

18. Zellmer, supra note 16, at 239.

19. Id. at $239-40$ ("[C]laims such as those brought by landowners affected by the 2011 Missouri/Mississippi flood should be treated as torts ....").

20. Id. ("[C]laims such as those brought by Gulf Coast residents inevitably flooded by the 
threat of tort litigation may not deter officials from acting and may instead encourage them "to make more proactive decisions to operate their flood control structures to better protect vulnerable areas and human and ecological communities and to restrict or at least mitigate the effects of unsustainable development." 21 I instead propose that takings claims should not require a showing of purpose, intent, or substantial certainty of the consequence. Takings claims should function to spread the risk by distributing equitably the benefits and burdens of actions intended for the public benefit. Such an approach would encourage communities and local government to mitigate unsustainable development.

Certain firefighting situations also demonstrate the concept of "windfalls for wipeouts," such as when the government sets a backfire to protect adjacent landowners. ${ }^{22}$ Deciding where to set a backfire depends on a number of factors, such as the weather or specific geographic features. $^{23}$ Landowners do not know whether they will be harmed or granted a windfall if the backfire is set on their neighbors' land. ${ }^{24}$ Thus, a private market solution for redistributing windfalls is unlikely, and the government may be compelled to compensate landowners when it sets a backfire. ${ }^{25}$ Assigning a cost to the government will likely cause the government to adjust its behavior and use other firefighting techniques if, and when, the cost of using backfires increases. ${ }^{26}$

The disaster cycle includes the strategic processes of "mitigation, emergency response, insurance/liability compensation, [and] rebuilding." 27 This Article primarily addresses the insurance/liability compensation component of the disaster cycle with lesser emphasis on mitigation, emergency response, and rebuilding. If we as a society value using political and legal means to fairly distribute the benefits and burdens of our community life together, we must consider what mechanisms will be appropriate to account for the "takings" and "givings" that occur with government regulation, action, and inaction, as well as for climate change winners and losers. Providing public and private services that benefit the public as a whole will come at great cost

MRGO [Mississippi River Gulf Outlet] navigational canal should be treated as takings.”).

21. Id. at 240.

22. Karen M. Bradshaw, Backfired! Distorted Incentives in Wildfire Suppression Techniques, 31 UTAH ENVTL. L. REV. 155, 168 (2011) [hereinafter Bradshaw, Backfired!].

23. Id.

24. Id.

25. Id. at 169 .

26. Id.

27. Daniel A. Farber, Introduction: Legal Scholarship, the Disaster Cycle, and the Fukushima Accident, 23 Duke ENVTL. L. \& POL'Y F. 1, 3 (2012). 
and we need a better understanding of how we will pay for these costs. Tort liability, insurance, utility rates, personal responsibility, taxation at the federal, state, and local level, and just compensation for eminent domain or inverse condemnation are just some of the remedies we have used in the past to spread the costs of providing public benefits.

Part I begins with a brief history of eminent domain and a discussion of federal and state takings clauses and the concept of "public use." It then focuses on issues that arise in delegating this power to private actors such as utilities, corporations, and redevelopment agencies. With the delegation of eminent domain power to private entities comes responsibility for just compensation, tort damages, and inverse condemnation under state damagings clauses for actions that benefit the public. However, the increasing costs of intensifying disasters cannot be entirely borne by governments and private actors. If we bankrupt the entities providing public benefits by holding them responsible for the damages caused by beneficial activities, we will eventually face rising costs for these benefits through taxation, pricing, insurance, or litigation, as well as the possibility of driving these entities out of the business of providing public benefits.

Part II explores using inverse condemnation and damagings claims under the Fifth Amendment Takings Clause and state constitutional provisions to distribute the costs of providing public benefits in the face of disaster. This discussion will focus primarily on damages caused by flooding, wildfires, and storms, which have all increased in intensity with climate change. The success of using inverse condemnation or damagings claims to recover from entities operating for the public benefit will depend on the jurisdiction's approach to these claims and the individual factual situations. Once a court determines that a taking has occurred, just compensation will be required. Part II discusses some of the issues landowners face when claiming just compensation as the remedy.

Part III addresses tort liability and insurance as additional means to compensate landowners for damages from disasters related to the provision of public benefits. Tort liability may or may not be effective in compensating private landowners if sovereign immunity shields the government entity. Distinguishing between tort claims and inverse condemnation or damagings claims under state law is at times problematic. Insurance policies or federal and state insurance funds may be available to allow landowner recovery for disaster damages. However, insurers may also assert subrogation claims against public entities for reimbursement of costs. I suggest that insurers should only be able to assert subrogation claims against public or private entities 
when there is tort liability for negligence or nuisance, not for inverse condemnation or damagings claims.

Part IV briefly examines some of the remaining relevant processes of the disaster cycle involving mitigation, emergency response, and rebuilding. The Conclusion suggests alternatives for dealing with the compensation portion of the disaster cycle and proposes that inverse condemnation and damagings claims be employed as a cost-spreading mechanism. Tort concepts and defenses should not be applicable to these claims because the Fifth Amendment Takings Clause "was designed to bar Government from forcing some people alone to bear public burdens which, in all fairness and justice, should be borne by the public as a whole." 28

\section{EMINENT DOMAIN AND THE FEDERAL AND STATE TAKINGS Clauses}

\section{A. Background}

Scholars have traced the history of the eminent domain power as far back as the Bible where "the prophet Samuel informs the people of Israel that the king 'will take your fields, and your vineyards, and your oliveyards, even the best of them.", 29 In 1215, the Magna Carta required that before crown officials could seize chattels from a "free man," there needed to be a "legal judgment of his peers or by the law of the land" and crown officials had to immediately pay money for these seized chattels. ${ }^{30}$ While the U.S. Constitution does not "explicitly grant[] the power of eminent domain to the national government," the Fifth Amendment requires that the government pay just compensation for a taking. ${ }^{31}$

Two historical justifications for eminent domain were: 1) the innate power of government sovereignty and 2) the right of the government, as "[t]he root of all title," to reclaim property previously granted to the individual. ${ }^{32}$ However, in modern times, the takings power is justified by

"concerns of distributive justice" and "economic or planning

28. Armstrong v. United States, 364 U.S. 40, 49 (1960).

29. Abraham Bell, Private Takings, 76 U. CHI. L. REv. 517, 524 (2009) (quoting 1 Samuel 8:14 (King James)).

30. Id. at 525 (quoting MAGNA CARTA, chs. 28, 39 (1215), reprinted in SOURCES OF OUR LiBERTIES: DOCUMENTARY ORIGINS OF INDIVIDUAL LIBERTIES IN THE UNITED STATES Constitution And BiLl of Rights 11, 16, 17 (Richard L. Perry \& John C. Cooper eds., 1959)).

31. Id. (citing U.S. CONST. amend. V).

32. Id. at 526 . 
efficiency." ${ }^{33}$ Thus, the power of eminent domain plays a major role in distributing the burdens of disasters and in planning for increasing damages. The concept of just compensation has existed since the beginning of the American colonial period ${ }^{34}$ and has been justified by the rationale that "when some contribution must be made to preserve a common thing by such as participate in its benefits, each of them contributes only his own share, and no one bears a greater burden than another." 35 The U.S. Supreme Court in Armstrong v. United States reiterated this rationale, stating the "Fifth Amendment's guarantee that private property shall not be taken for a public use without just compensation was designed to bar Government from forcing some people alone to bear public burdens which, in all fairness and justice, should be borne by the public as a whole." 36

\section{B. Federal and State Takings Clauses}

The Takings Clause of the Fifth Amendment, made applicable to the states through the Fourteenth Amendment, provides that "nor shall private property be taken for public use without just compensation."37 Most states have a similar takings clause in their constitutions, ${ }^{38}$ and "[f]ederal and state takings clauses are generally interpreted the same way." 39 For eminent domain actions, the two primary issues are whether the taking is for a public use and whether the government pays just compensation.

The question as to whether the taking is for a public use is most recently guided by the Supreme Court's Kelo v. City of New London decision, which affirmed a broad reading of public use for the federal Constitution, but encouraged states to define the term more narrowly if they so desired. ${ }^{40}$ In Kelo, the City of New London approved a private

33. Id. at 528 .

34. James W. Ely, Jr., "That Due Satisfaction May Be Made:" The Fifth Amendment and the Origins of the Compensation Principle, 36 AM. J. Legal HIST. 1, 11-13 (1992); William B. Stoebuck, A General Theory of Eminent Domain, 47 WASH. L. REV. 553, 583 (1972).

35. Stoebuck, supra note 34, at 584 (quoting SAMUEL Von PufENDORF, DE JuRE NATURAe ET GENTIUM LiBRI OCTO 1285 (Walter Simons ed., C.H. Oldfather \& W.A. Oldfather trans., Clarendon Press 1934) (1672)).

36. 364 U.S. 40,49 (1960).

37. U.S. CONST. amend V.

38. Michael B. Kent, Jr., Public Pension Reform and the Takings Clause, 4 BeLmont L. ReV. 1, 4 (2017).

39. Thomas W. Merrill, Anticipatory Remedies for Takings, 128 HARV. L. REV. 1630, 1631 (2015).

40. 545 U.S. 469,489 (2005) ("[N]othing in our opinion precludes any State from placing 
development plan to revitalize the City and assembled the land needed for the project through voluntary purchase and the use of eminent domain. ${ }^{41}$ Nine of the condemnees, including Susette Kelo, challenged the City's action, claiming that the taking would violate the Fifth Amendment's "public use" restriction. ${ }^{42}$ The Court held that based on its precedential cases of Berman v. Parker ${ }^{43}$ and Hawaii Housing Authority v. Midkiff, "using eminent domain to promote economic development" was "for a 'public use' within the meaning of the Fifth Amendment to the Federal Constitution." 45

In the years following the Kelo decision, at least "forty-four states have either amended their constitutions or enacted legislation... to address the ['public use'] concerns expressed by Justice O'Connor's dissent." "46 These actions have varied, but they mostly focus on restricting the use of eminent domain actions for economic development and requiring a finding of blight. ${ }^{47}$

At the state level, challenging public use is a developing area of law in terms of whether an entity may use eminent domain for economic development or when negotiations for a lease or purchase fail. ${ }^{48}$ In approximately forty states, it is illegal to use eminent domain for economic development. ${ }^{49}$ Several cases have also held that using eminent domain to condemn property is not proper when "a government entity has been unhappy with lease or purchase negotiations and then uses eminent domain to get the deal it wanted." ${ }^{50}$ Using eminent domain for redevelopment or blight removal continues to be an active and demanding area of litigation. ${ }^{51}$

further restrictions on its exercise of the takings power.").

41. Id. at 472 .

42. Id. at 475 .

43. 348 U.S. 26, 33 (1954) (upholding redevelopment plan targeting blighted area in Washington, D.C. even though not all properties condemned were blighted).

44. 467 U.S. 229, 241-42 (1984) (upholding Hawai'i statute that transferred fee title from lessors to lessees to reduce concentration of land ownership).

45. Kelo, 545 U.S. at 489-90.

46. David L. Callies, Robert H. Freilich \& Shelley Ross Saxer, Land Use Cases and MATERIALS 340 (7th ed. 2017).

47. See David L. Callies, Kelo v. City of New London: Of Planning, Federalism, and a Switch in Time, 28 U. HAW. L. REV. 327, 344-45 (2006).

48. See Dana Berliner et al., Challenging the Right-To-Take: A Whirlwind Tour of Cases and Issues, A.L.I. CONTINUING LEGAL EDUC., Feb. 5-7, 2015, at 631.

49. Id. (discussing cases holding economic development is not a public use).

50. Id. (discussing cases rejecting and upholding condemnations used for such purposes).

51. See, e.g., Reading Area Water Auth. v. Schuylkill River Greenway Ass'n, 100 A.3d 572, 573, 582-84 (Pa. 2014) (holding municipal authority asserting condemnation power was not a public utility, and thus condemnation of a drainage easement for the benefit of the private developer 


\section{Delegating Eminent Domain Power to Private Actors for the Public Good}

Beginning in the eighteenth and nineteenth centuries, federal and state governments delegated the power of eminent domain to private actors, including "turnpike, bridge, canal, and railroad companies," as well as to mill owners who could use eminent domain to "dam watercourses and flood neighboring land in order to power mills." 52 Although state law retreated significantly from using eminent domain in the early twentieth century, many states continue to allow private takings by private actors. ${ }^{53}$ Using this power in times of disaster requires the government and private entities to make decisions about how to distribute public benefits and burdens. Government agencies must decide whether to flood downstream property to protect upstream property or vice versa when superstorms produce substantial quantities of floodwater.

Firefighting authorities must decide whether and where to set backfires to prevent excessive damage from wildfire depending upon geography and other conditions. Private electric utilities, whose power lines cause wildfires and resulting mudflows, face the prospect of powering down their electrical equipment and cutting power to millions during red flag warnings for severe winds. These actions may prevent damage and injury to some, but may inflict harm on others.

Granting a private taking power is appropriate in situations where "the private market [is] parallel to those where the exercise of a governmental taking power is warranted." ${ }^{\circ 4}$ A private taking power is indicated if: "(1) the taker is the preferred owner of the property right (for reasons of justice or efficiency); and (2) strategic difficulties block the efficient or just transfer of property rights in the market place." ${ }^{55}$ Some critics of private takings assert "the government is more likely than private actors to make decisions for the benefit of the public and that the

violated the Property Rights Protection Act); $c f$. Wymberley Sanitary Works v. Batliner, 904 N.E.2d 326, 334 (Ind. Ct. App. 2009) ("The mere fact that the sewer line extension will enhance the value of the subdivision to the developer does not alter the fact that there is a public benefit as well.").

52. Bell, supra note 29 , at 545.

53. Id. at $545-46$.

54. Id. at 558 .

55. Id. at 558-59 (proposing three keys to determine government delegation to private actors: (1) "likelihood of strategic barriers blocking efficient transfers"; (2) "some reliable mechanism for determining that the taking effectuates a transfer to a desirable owner" (just compensation is a basic requirement); and (3) "the pliability rule created by the private taking power should be superior to alternative pliability rules, or government mediation"). 
public benefit is more likely to be served when taken property is held by the government than when held by private actors." ${ }^{, 56}$ However, empirical studies show that outsourcing to private providers is more efficient than public services. $^{57}$

There are conflicts in regards to the authority that private actors and government officials possess to use eminent domain and whether the power has been properly delegated. The eminent domain power is an aspect of sovereignty that allows federal or state governments to condemn property for public use so long as they pay just compensation. ${ }^{58}$ The state holds the right of eminent domain, which it can delegate by statute to counties, municipalities, or public service corporations. "[T]here is a hierarchy among public entities ... with the [s]tate at the top," as to when they may use eminent domain to condemn land for incompatible public uses. ${ }^{59}$ The legislature may constitutionally delegate the eminent domain power to private development corporations "if a public purpose is thereby advanced, and the benefit of the property taken" is available to the public. ${ }^{60}$

Eminent domain is a powerful tool for both governments and those to whom it delegates this power. The concept of what constitutes a public use is very broad, but there are limitations on the delegation of power to private entities. Even when states have not statutorily tightened the use of eminent domain by private entities after Kelo, courts will often strictly construe the statutory authority for delegation based on the grant of power and any procedural requirements governing the exercise of that power.

\section{USING INVERSE CONDEMNATION OR DAMAGINGS CLAIMS TO PAY FOR BURDENS CAUSED BY PROVIDING PUBLIC BENEFITS}

Assuming that the eminent domain power is for a public use and that the state has properly delegated this power to the public or private actor, there are consequences and responsibilities that come with using this power. As our population grows and the consequences of climate change escalate, our infrastructure needs increase. Various levels of government (federal, state, and local), private entities serving the public good, and private property owners have come into conflict over who will ultimately

\footnotetext{
56. Id. at 575 (footnote omitted).

57. Id. at 576 .

58. See id. at 526 .

59. 26 AM. JUR. 2D Eminent Domain $\S 23$, Westlaw (database updated November 2019).

60. Id. § 28 .
} 
pay for these public needs.

This Part discusses the responsibilities of governments and private entities holding the eminent domain power when they face state damagings and inverse condemnation claims. For example, damaged landowners have sought recovery against electric utilities for causing wildfires ${ }^{61}$ or against public or private entities for flooding due to direct action or a failure to act. ${ }^{62}$ Disasters generate the need to compensate for damages to public and private property through tort liability, state damagings clauses, and insurance. Other mechanisms exist to compensate for disasters, such as federal and state disaster relief, tax policy, victim compensation funds, employment laws, bankruptcy provisions, disaster loans or bonds, and charitable donations. ${ }^{63}$ However, this Article primarily addresses just compensation under the Fifth Amendment, inverse condemnation and damagings under state law, tort liability, and insurance coverage.

\section{A. The Fifth Amendment, State Damaging Clauses, and Inverse Condemnation Claims}

We must answer the question of who will pay for the damage as we confront the increasing frequency and severity of disastrous events that test the sufficiency and resiliency of existing infrastructure. With tort liability potentially subject to sovereign immunity, damaged landowners have turned to takings claims to require just compensation for government actions when their property rights are sacrificed for the public benefit. ${ }^{64}$ Damagings clauses developed in the 1800 s following public infrastructure projects that damaged adjoining property without compensating landowners for a loss of access. The 1823 Massachusetts

61. See, e.g., Barham v. S. Cal. Edison Co., 88 Cal. Rptr. 2 d 424 (Ct. App. 1999).

62. See, e.g., Arreola v. County of Monterey, 122 Cal. Rptr. 2d 38 (2002) (property owners sued the county and the water agency after the defendants failed to maintain property, causing a levee to break during a storm, which caused flooding).

63. See, e.g., Danshera Cords, Charitable Contributions for Disaster Relief: Rationalizing Tax Consequences and Victim Benefits, 57 CATH. U. L. REV. 427 (2008); Nathan Smith, Comment, Water, Water Everywhere, and Not a Bite to Eat: Sovereign Immunity, Federal Disaster Relief, and Hurricane Katrina, 43 SAN Diego L. REV. 699 (2006); Mark G. Jeffries, What To Do (and Not Do) When Disaster Strikes, 22 No. 2 W. VA. EMP. L. LETTER 1, 1 (2016) (discussing business obligations to employees when disaster hits a community under the Fair Labor Standards Act and the U.S. Department of Labor standards of practice); Francine J. Lipman, Anatomy of a Disaster Under the Internal Revenue Code, 6 FLA. TAX REV. 953 (2005); Jean Macchiaroli Eggen, Toxic Torts at Ground Zero, 39 ARIZ. ST. L.J. 383 (2007) (discussing toxic tort claims for those exposed to toxic substances in and around Ground Zero).

64. See discussion supra Section I.A. 
decision in Callender v. Marsh ${ }^{65}$ was "the original change-of-grade case, in which the cutting down of a street blocked an abutting owner's access onto it." ${ }^{\prime 66}$ The Callender court denied the landowner compensation for the loss of access because "no land had been touched." 67 This view of "no taking without a touching" was prevalent for over a hundred years and "the physical concept still exerts a heavy influence in some opinions" unless a state constitution or statute allows compensation for a "damaging." 68

As the nation built freeways and highways across established road networks, this process created street closures, lack of access, or other street blockages, and "the long-range tendency of courts has been toward giving compensation on account of unreasonable loss of access." ${ }^{\circ 9}$ A similar situation involving riparian rights can arise where "the owner may suffer loss or diminution of [riparian rights] due to the acts of a body having eminent domain power." "70 In particular, many decisions have recognized that a taking might occur when the eminent domain entity blocks access, pollutes the water, changes the flow or level of the water, or restricts the riparian owner's surface use. ${ }^{71}$ Some courts, however, use nuisance theory to analyze the problem or view the public body's actions as exercising the police power. ${ }^{72}$

Scholars and practitioners have mostly ignored the damagings clauses contained within many state constitutions or statutes until recently. ${ }^{73}$ Professor Brady takes a historical and comprehensive look at damagings clauses, contained in twenty-seven state constitutions:

More than half of the state constitutions contain a takings clause that is materially different from the federal one, in that it prohibits property from being both "taken" and "damaged" or "injured" for public use without just compensation. Despite their ubiquity, these "damagings clauses" have received minimal attention in the literature on property law....

... Studying the damagings clauses helps reveal a gap in the coverage of conventional condemnation law: in the process of building

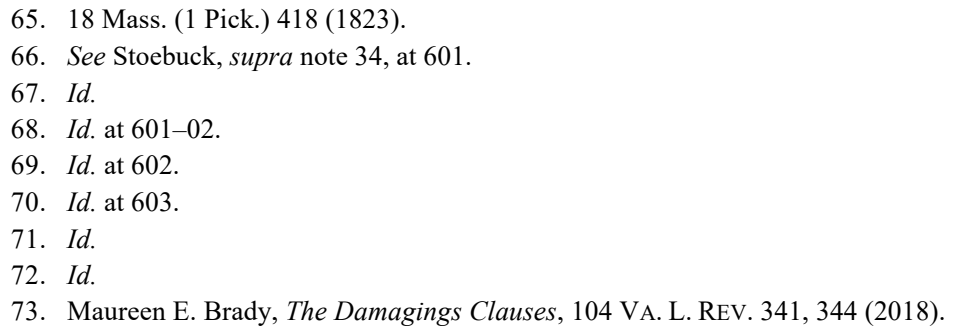


and using something for public benefit, the government can drastically impair and devalue adjoining or nearby property, yet this is neither a physical taking (an actual appropriation of property) nor a regulatory taking (a regulation that so interferes with property rights that it triggers the just compensation requirement). The damagings clauses were intended to cover these interstitial harms, those where nothing has been taken or regulated, but landowners are nonetheless unfairly burdened by a project for public benefit. Despite the overwhelming evidence that the clauses were meant to cover these injuries, as time passed, state-court judges rendered the clauses fairly impotent. ${ }^{.74}$

In recent years, states have rejected most damagings claims except for those alleging a total loss of access or a physical invasion. ${ }^{75}$ States intended that damagings clauses would "cover these interstitial harms, those where nothing has been taken or regulated, but landowners are nonetheless unfairly burdened by a project for public benefit." 76 Litigants damaged by floods or wildfires have increasingly turned to state inverse condemnation and damagings clauses to address government or private actions that were intended to benefit the public, but have instead damaged individual landowners. The following discussion is not an exhaustive review of all recent cases, but it explores examples that address the gap in landowner remedies and provides insight into how existing damagings clauses or the Fifth Amendment may provide compensation for landowners damaged by increasing disasters.

\footnotetext{
74. Id. at 344-46 (emphasis added) (footnotes omitted).

75. Id. at 388-93 and accompanying notes; see also Padilla v. Metro. Transit Auth. of Harris Cty., 497 S.W.3d 78, 84 (Tex. App. 2016) (holding that if property owner establishes that government "materially and substantially impaired access rights to his property," the owner is entitled to compensation for lost profits arising from denial of access); In re Petition of Grand River Dam Auth., 484 P.2d 505, 512 (Okla. 1971) ("[W]here special damage results from injury which is different from that suffered by community in general, as where ingress or egress is cut off, or materially affected, action in nature of damages for reverse condemnation may be maintained... [even when] exercise of eminent domain is not involved ...." (citing Atchison, Topeka \& Santa Fe Ry. v. Terminal Oil Mill Co., P.2d 617 (Okla. 1937); Okla. Tpk. Auth. v. Chandler, 316 P.2d 828 (Okla. 1957))); Schliem v. State ex rel. Dep't of Transp., 888 N.W.2d 217, 224 (S.D. 2016) (noting "the drafters of South Dakota's constitution added the words or damaged" to cover a situation when there was not an actual taking of the thing, but finding the property owner entitled to no compensation because he did not show that his access was destroyed or substantially impaired); SDS, Inc. v. State Dep't of Transp. \& Dev., 978 So. 2d 1013, 1015 (La. Ct. App. 2008) (noting the Louisiana Constitution provides for compensation through inverse condemnation when a landowner suffers damage without expropriation).

76. See Brady, supra note 73 , at 345-46.
} 


\section{Flooding}

Natural events such as hurricanes and super storms may cause massive flooding damages to private and public property, but "the armoring of rivers, hardening of floodplains, and development of watersheds increases the severity of the flood itself" and transforms these events into disasters. ${ }^{77}$ In spite of recognizing that human behavior in planning and developing land increases our vulnerability to disaster, we continue to build in areas that we know are at risk for natural events. ${ }^{78}$

Those who have studied society's response to addressing natural hazards, both before a disaster and after, have identified obstacles to reforming our policies based on set patterns of thinking and structures of government. ${ }^{79}$ For example, providing federal flood insurance to those living in floodplains and unable to obtain private insurance encourages development by underpricing risk. ${ }^{80}$ Recurring payments to address policyholder claims for flood damages encourage constant reconstruction. ${ }^{81}$ Even though communities "should carefully consider rebuilding in hazard-prone locations following disaster," 82 human societies have generally refused to relocate. ${ }^{83}$ As victims of disasters and climate change seek damages to address recurring losses, "we can no longer afford to simply build and rebuild in a continuing cycle of destruction." 84

State courts, the Federal Court of Claims, the Federal Circuit, and the Supreme Court continue to struggle with developing a coherent and consistent approach to resolving past and future flooding claims involving hydro-infrastructure. Some states require negligence or nuisance by the public or private entity providing a public benefit before giving a landowner remedy for damagings. Other states, including California, use strict liability under a constitutional standard rather than a

77. Justin Pidot, Deconstructing Disaster, 2013 BYU L. REV. 213, 214-16 (discussing the history of disaster policy and society's response as we continue to build and rebuild physical infrastructure in hazardous locations).

78. Id. at 215-17 ("Within Florida, development is concentrated in counties facing particularly acute hurricane risks.").

79. Id. at 218-19 (identifying and discussing three categories of obstacles-symbolic, cognitive, and structural).

80. Id. at 219 (discussing impact of National Flood Insurance Program on development).

81. Id. at 220 .

82. Id. (citing Lisa Grow Sun, Smart Growth in Dumb Places: Sustainability, Disaster, and the Future of the American City, 2011 BYU L. REV. 2157 (2011)).

83. Id. ("Between the twelfth century and the nineteenth century, only forty-two cities worldwide were permanently abandoned following catastrophe.").

84. Id. at 224 . 
tort standard, but temper this liability with a reasonableness rule for claims based on public flood control programs. Damagings cases often result from city infrastructure that fails for lack of maintenance or because of an overload to the infrastructure caused by extreme weather. More recently, "failure to adapt" litigation has tested the legal responsibilities of government and private owners of energy infrastructure to prepare for extreme weather events and reform constitutional, tort, and statutory law to reduce climate change related risks. ${ }^{85}$

a. Tort or Taking in the Federal Courts?

The Federal Circuit has distinguished between a tort and a taking to find that while government inaction may be the basis for a tort claim, a takings claim requires affirmative government action. In St. Bernard Parish Government v. United States, property owners in St. Bernard Parish and the Lower Ninth Ward of the City of New Orleans alleged a taking against the federal government. ${ }^{86}$ The plaintiffs based their suit on the theory that "government inaction, including the failure to properly maintain or to modify the Mississippi River-Gulf Outlet ('MRGO') channel, and government action (the construction and operation of the MRGO channel)" caused flood damage to their properties from Hurricane Katrina and other hurricanes. ${ }^{87}$ The Court of Federal Claims held that a taking occurred and awarded the property owners just compensation. ${ }^{88}$ However, the Court of Appeals for the Federal Circuit reversed the takings win for the owners, holding that "the government cannot be liable on a takings theory for inaction and that the government action in constructing and operating MRGO was not shown to have been the cause of the flooding." 89

The Federal Circuit in St. Bernard Parish relied on Arkansas Game $\&$ Fish Commission v. United States ${ }^{90}$ and United States $v$.

85. Dena Adler, Turning the Tide in Coastal and Riverine Energy Infrastructure Adaptation: Can an Emerging Wave of Litigation Advance Preparation for Climate Change?, 4 OIL \& GAS, NAT. RESOURCES \& ENERGY J. 519, 520 (2018).

86. 887 F.3d 1354, 1357 (Fed. Cir. 2018), cert denied sub nom. St. Bernard Par. v. United States, 139 S. Ct. 796 (2019) (mem.).

87. Id.

88. Id.

89. Id.

90. 568 U.S. 23, 27-28 (2012) (finding that an affirmative government action in releasing water may give rise to a temporary takings claim). 
Sponenbarger" to find "that takings liability does not arise from government inaction or failure to act" and that "[p]laintiffs' sole remedy for these inactions, if any, lies in tort." 92 The St. Bernard Parish court explained that while a government failure "to maintain or modify a government-constructed project may state a tort claim," a takings claim requires affirmative government acts and, unlike a tort claim, the government's takings liability does not depend on its level of care. ${ }^{93}$ St. Bernard Parish filed a Petition for a writ of certiorari, which the Supreme Court denied on January 7, 2019 without comment. ${ }^{94}$ Some argue that because the Court's decision in Arkansas Game reversed the Federal Circuit's adoption of a categorical rule "that the Government is always immune from takings liability for inaction," the St. Bernard Parish decision was incorrect in relying on Arkansas Game for its holding that only government action creates takings liability. ${ }^{95}$ While there is support for holding the government liable for taking private property based on government inaction, the Supreme Court may not definitively answer the issue for years.

The U.S. Supreme Court in Arkansas Game concluded that "government-induced flooding can constitute a taking of property" $" 96$ and that recurrent floodings, even if temporary, "are not categorically exempt from Takings Clause liability." 97 In remanding the takings claim, the Court noted that the Federal Circuit should also examine Arkansas waterrights law in resolving the Arkansas Game and Fish Commission's claim that flooding authorized by the U.S. Army Corps of Engineers damaged or destroyed timber on forestland it owned and managed. ${ }^{98}$

Guided by the Court's decision in Arkansas Game, the Federal Court of Claims in In re Upstream Addicks \& Barker (Texas) Flood-Control Reservoirs addressed property owner claims against the government for flooding that occurred after Hurricane Harvey in August 2017.99 Thousands of homes and businesses in the Houston, Texas area were

\footnotetext{
91. 308 U.S. 256, 265 (1939) ("When undertaking to safeguard a large area from existing flood hazards, the Government does not owe compensation under the Fifth Amendment to every landowner which it fails to or cannot protect.").

92. St. Bernard Par., 887 F.3d at 1361-62.

93. Id. at 1360 .

94. See St. Bernard Par. v. United States, 139 S. Ct. 796 (2019).

95. Petition for Writ of Certiorari at 1-2, St. Bernard Par., 139 S. Ct. 796 (2019) (mem.) (No. 18-359) (citing Ark. Game \& Fish Comm'n v. United States, 568 U.S. 23 (2012)).

96. 568 U.S. 23,34 (2012).

97. $I d$. at 27 .

98. Id. at 26,38 .

99. 138 Fed. Cl. 658, 660-61 (2018).
} 
flooded, including over 10,000 private properties "upstream of the federally designed, built, and maintained Addicks and Barker Dams.",100 The upstream landowners brought suit "alleging an uncompensated taking under the Fifth Amendment." 101 The court examined the sufficiency of the plaintiffs' takings claims in Upstream Addicks and explained that courts assess takings claims on the particular facts of each case. $^{102}$ A takings claim based on a temporary physical invasion is "subject to a more complex balancing process to determine whether" a taking occurred. ${ }^{103}$

For flooding cases, there are five factors relevant to whether the government's actions constituted a compensable taking of property: (1) "time- the duration of the physical invasion"; (2) "causation"; (3) "intent or foreseeability"; (4) "the owner's reasonable investment-backed expectations regarding the land's use"; and (5) the "[s]everity of the interference." 104 Finally, plaintiffs bringing inverse condemnation claims from government-induced flooding must show that "treatment under takings law, as opposed to tort law, is appropriate under the circumstances." 105 Claims against the United States "sounding in tort" lack jurisdiction under the Tucker Act because they are not takings claims founded on the Fifth Amendment. ${ }^{106}$

In addressing the federal government's claim that the plaintiffs could not state a takings claim based on government inaction, the Upstream Addicks court noted that " $[\mathrm{t}]$ he government acted when it built and then modified the dams in such a way that they could and did impound storm water behind the dams on both government and private property."107 The court held that plaintiffs adequately alleged government action sufficient for a taking claim based on the government's intent and foreseeability of the alleged takings. ${ }^{108}$ The government was aware of the risks posed to private property by the dams' designs and knew how it could mitigate those risks. ${ }^{109}$

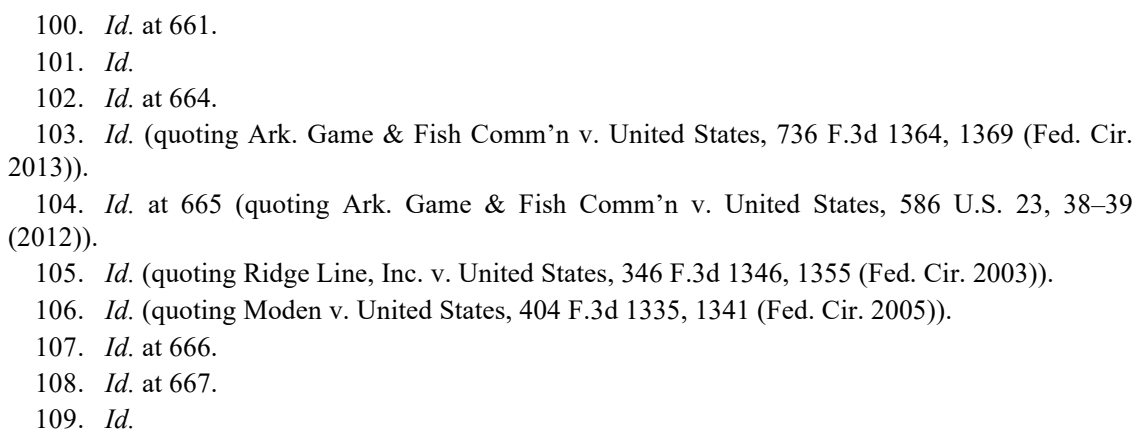


In a subsequent federal lawsuit against the Army Corps of Engineers (Corps), farmers, landowners, and business owners claimed that the Corps' actions on the Missouri River "resulted in the taking of flowage easements on their properties without just compensation." 110 The Corps was obligated to make changes to the Missouri River to protect fish and wildlife species, which allegedly caused increased flooding of the private property. ${ }^{111}$ The court in Ideker Farms found that although many of the plaintiffs had shown causation and foreseeability in several of the flooding incidents from 2007 to 2014, they failed to prove causation for the flooding in 2011. ${ }^{112}$ The plaintiffs' allegations that the Corps' failure to release water from the reservoirs caused the flooding sounded in tort based on government inaction and the St. Bernard Parish decision clearly established that inaction cannot support a takings claim. ${ }^{113}$ The government argued that the plaintiffs did not prove that the Missouri River System and the flood reduction actions caused the flooding, but the court noted that its earlier findings did not support the government's argument. ${ }^{114}$ In view of the decision in St. Bernard Parish, the court denied both the plaintiffs' and the government's motions for reconsideration. ${ }^{115}$

Following the U.S. Supreme Court holding in Arkansas Game that "government-induced flooding can constitute a taking of property," 116 Federal Claims and Federal Circuit decisions have distinguished between flooding claims alleging damage based on government inaction and flooding claims based on government acts. Government inaction can only be addressed using tort, while government action may support a takings claim. As discussed above, the Court's denial of certiorari for the Federal Circuit's decision in St. Bernard Parish leaves litigants uncertain as to whether government inaction may serve as the basis for a takings claim.

\footnotetext{
110. Ideker Farms, Inc. v. United States, 142 Fed. Cl. 222, 223 (2019).

111. Id.

112. Id. at $224-25$.

113. Id. at 231 .

114. Id. at 232 (“' $[\mathrm{C}]$ hanges made to the Corps' River and Mainstem system after the court order requiring the Corps' compliance with the [Endangered Species Act] increased flooding to a degree that would not have been contemplated when the River and Mainstem System structures were planned.").

115. Id. at 228 .

116. Ark. Game \& Fish Comm'n v. United States, 568 U.S. 23, 34 (2012).
} 
b. Tort or Taking in the State Courts?

States have offered different rationales to determine whether public or private entities acting for the public benefit are immune from tort liability for private property damages or whether an inverse condemnation claim requires a finding of negligence or nuisance. ${ }^{117}$ The Arkansas Supreme Court in Robinson v. City of Ashdown noted "courts have not been clear in presenting their rationales in cases where statutes conferring immunity from tort liability upon municipalities have been held inapplicable to facts which amount to negligence or nuisance." 118

Determined to make its rationale clear, the Robinson court found the City of Ashdown liable for failing to remedy its sewer plant operation that caused sewage overflow. ${ }^{119}$ It relied on the Arkansas constitutional provision that "private property shall not be taken, appropriated, or damaged for public use, without just compensation."120 The court declared, "When a municipality acts in a manner which substantially diminishes the value of a landowner's land, and its actions are shown to be intentional, it cannot escape its constitutional obligation to compensate for a taking of property on the basis of its immunity from tort action."121 The Arkansas Supreme Court thus explicitly based its finding of liability for inverse condemnation actions on the damagings clause in its constitution, not on negligence or nuisance.

Other states have been less clear in distinguishing between tort and inverse condemnation. For example, Utah law specifically precludes recovery of property damages caused by negligence in an action for inverse condemnation. ${ }^{122}$ Utah's Constitution provides that "[p]rivate property shall not be taken or damaged for public use without just compensation," 123 which allows a property owner to bring an inverse condemnation action for damages so long as the elements of a property interest, a takings or damaging, and a public use are met. ${ }^{124}$ The Utah Supreme Court in Farmers New World Life Insurance Co. v. Bountiful

117. See Robinson v. City of Ashdown, 783 S.W.2d 53, 55-56 (Ark. 1990) (citing A. W. Gans, Annotation, Damage to Private Property Caused by Negligence of Governmental Agents as "Taking," "Damage," or "Use" for Public Purposes, in Constitutional Sense, 2 A.L.R.2d 677 (1948)).

118. Id. at 56 .

119. Id.

120. Id. (quoting ARK. CONST. art. II, § 22).

121. Id. at $56-57$.

122. See Thomas E. Jeremy Estate v. Salt Lake City, 49 P.2d 405, 407 (Utah 1935).

123. UTAH CONST. art. I, $\S 22$.

124. Farmers New World Life Ins. Co. v. Bountiful City, 803 P.2d 1241, 1243-44 (Utah 1990). 
City held that "under [Utah] statutes and case law, damages which are not a direct and necessary consequence of the construction or operation of a public use are not recoverable in an inverse condemnation action." ${ }^{125}$ Because there was "no evidence that the injuries incurred by Farmers were unavoidable or necessary to the construction or use of the culvert," Farmers' claim for damage caused by losing lateral support when Bountiful City constructed a culvert for flood control was not recoverable under inverse condemnation. ${ }^{126}$ Instead, the "damages must 'grow out of' a public use rather than being merely the result of a negligent or wrongful government act," and the injuries Farmers experienced did not provide any public benefit. ${ }^{127}$ This rule requires the government to pay inverse condemnation damages only when it is not at fault, not regardless of fault. In Utah, if there is fault on the part of the government, the injured property owner must present a tort claim, not an inverse condemnation claim.

The Supreme Court of North Carolina has taken a different approach. In Wilkie v. City of Boiling Spring Lakes, the court determined that the City of Boiling Spring Lakes' action in raising the lake level for private landowners surrounding the lake, causing flooding to the plaintiffs' property, was a compensable inverse condemnation claim. ${ }^{128}$ The court explained:

Although a condemning entity must establish that a proposed taking will further a public purpose before a condemnation can be authorized, we can see no reason why a reciprocal burden to establish the existence of a public purpose should be imposed upon a property owner who has been deprived of his or her property by governmental action taken for a non-public purpose. ${ }^{129}$

Thus, while Utah required inverse condemnation damages to "'grow out of' a public use rather than being merely the result of a negligent or

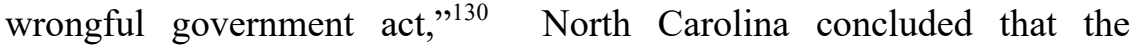
statutory inverse condemnation remedy under state law does not depend on the purpose that led to the property owner's injury. The court determined that "it makes no sense" to provide just compensation only

\footnotetext{
125. Id. at 1245 .

126. Id. at 1246.

127. Id. (quoting Springville Banking Co. v. Burton, 349 P.2d 157, 166 (1960) (Wade, J., concurring)).

128. 809 S.E. $2 \mathrm{~d} 853,861$ (N.C. 2018).

129. Id. at 862 .

130. Farmers New World Life, 803 P.2d at 1246.
} 
"if the government does the right thing but not if it does the wrong thing." 131

Texas requires that inverse condemnation claims based on flooding be permanent in nature and result from intentional government action. ${ }^{132}$ Recurrent flooding events are a prerequisite to finding a taking as Texas courts struggle in separating tort claims from inverse condemnation claims. ${ }^{133}$ In Tarrant Regional Water District v. Gragg, the court drew the line between "liability for something less than intentional behavior," which would immunize an entity against negligence, and situations where "the requisite intent is present when a governmental entity knows that a specific act is causing identifiable harm or knows that the harm is substantially certain to result." 134 The court required evidence of recurrent flooding and noted that while a single flood event may cause damage, it "does not generally rise to the level of a taking." 135

In Harris County, Texas, the county created and adopted a floodcontrol plan in 1984 that was never fully implemented and subsequent flooding affected 400 homeowners in residential communities located in the upper White Oak Bayou watershed in 1998, 2001, and 2002. ${ }^{136}$ The affected homeowners sued the county for approving upstream development and failing to implement the 1984 flood control plan. ${ }^{137}$ The Texas Supreme Court in Harris County Flood Control District v. Kerr held that the government did not take the "homeowners' property by approving private development without fully implementing a previously approved flood-control plan."138 It noted that the homeowners' nuisance claim is dependent on the takings claim. ${ }^{139}$ If the plaintiffs cannot establish a constitutional taking, the government is immune from the nuisance claim. ${ }^{140}$ The Harris County court explained

131. Wilkie, 809 S.E.2d at 862 (quoting Harris Cty. Flood Control Dist. v. Kerr, 499 S.W.3d 793, 813 (Tex. 2016) (Lehrmann, J., concurring)).

132. Tarrant Reg'l Water Dist. v. Gragg, 151 S.W.3d 546, 555, 557-58 (Tex. 2004) (upholding the "trial court's finding that the reservoir's construction and operation intensified flooding at the Ranch" and finding that recurring flooding requirement "assures that the government is not held liable for taking property when a project's adverse impacts, and by implication its benefit to the public, are too temporal or speculative to warrant compensation").

133. Id. at 554-56 ("The cases reflect our efforts to account for several concerns in drawing the line between mere negligence and an unconstitutional taking.").

134. Id. at 554-55.

135. Id. at 555 .

136. Harris Cty. Flood Control Dist. v. Kerr, 499 S.W.3d 793, 795-96 (Tex. 2016).

137. Id. at 796-97.

138. Id. at 795 .

139. Id. at $795 \mathrm{n} .1$.

140. Id. 
that in order for plaintiffs to prevail on a takings claim under the Texas Constitution, they must prove that the government "intentionally took or damaged their property for public use, or was substantially certain that would be the result." 141 The failure to implement the flood control plan was inaction that did not support a takings claim because it was "not a case where the government made a conscious decision to subject particular properties to inundation so that other properties would be spared."142 The takings claim must result from an affirmative act of the government - nonfeasance will not support a takings claim. ${ }^{143}$

Illinois appears to accept inverse condemnation claims for government actions that damage private property owners without relying on tort concepts. However, it does require a showing of "radical interference with a private property owner's use and enjoyment of the property," which sounds in the tort of nuisance. ${ }^{144}$ For example, the Illinois Supreme Court in Hampton v. Metropolitan Water Reclamation District recognized that "[t]he takings clause of the Illinois Constitution provides greater protection for property owners than its counterpart in the United States Constitution, because it provides a remedy for property that is damaged, in addition to property that is taken."145 The plaintiffs alleged that flooding after a rainstorm damaged their properties because the water district diverted stormwater into nearby creeks, resulting in the creeks overtopping their banks and the sewers backing up. ${ }^{146}$ The court concluded that the plaintiffs had not sufficiently alleged a taking under Illinois law because they did not allege "that the flooding "radically interfered' with plaintiffs' use and enjoyment of their properties." 147

Virginia allows inverse condemnation for damages caused by a single occurrence of flooding. ${ }^{148}$ Similarly, Washington allows an inverse condemnation action without the government exercising its power of eminent domain and holds the government liable for flooding damages "if it concentrates and gathers water into artificial drains or

141. Id. at 799 (quoting City of Keller v. Wilson, 168 S.W.3d 802, 808 (Tex. 2005)).

142. Id. at 807 .

143. Id. at 800 .

144. Hampton v. Metro. Water Reclamation Dist., 57 N.E.3d 1229, 1238-39 (Ill. 2016).

145. Id. at 1240 .

146. Id. at $1232-33$.

147. Id. at $1240-41$ (reversing and remanding to allow the parties to brief issues surrounding damage claim, recognizing that "[t]he Illinois takings clause provides that the owner of damaged property has a right to just compensation").

148. Livingston v. Va. Dep't of Transp., 726 S.E.2d 264, 271 (Va. 2012) (holding that a single occurrence of flooding may give rise to compensable damaging, but only if it is foreseeable and a result of human agency, not natural causes). 
channels and discharges it upon adjoining lands in quantities greater than or in a manner different from the natural flow."149

In contrast to those states requiring negligence or nuisance, California's constitutional damagings provision as interpreted by the California Supreme Court does not require fault. ${ }^{150}$ However, flooding claims differ from wildfire claims in California courts, which have instituted a reasonableness standard in flooding cases. In Arreola v. County of Monterey, the court explained the legal background for an inverse condemnation action as follows:

"Private property may be taken or damaged for public use only when just compensation, ascertained by a jury unless waived, has first been paid to, or into court for, the owner." When a public use results in damage to private property without having been preceded by just compensation, the property owner may proceed against the public entity to recover it. Such a cause of action is denominated "inverse condemnation." 151

The court noted that an earlier California Supreme Court case, Albers $v$. County of Los Angeles, confirmed that the state constitutional provision was not just an exception to governmental immunity, but instead "provided a broader basis for governmental liability." 152

The Arreola court cited Albers's confirmation "that the fundamental policy basis for the constitutional requirement of just compensation is a consideration of "whether the owner of the damaged property if uncompensated would contribute more than his proper share to the public undertaking." "153 The only requirements for an inverse condemnation claim were that "(1) the injuries must be physical injuries of real property, and (2) the injuries must have been proximately caused by the public improvement as deliberately constructed and planned." 154

The Arreola court identified two exceptions to the rule that the "inverse condemnation plaintiff was entitled to compensation without regard to fault." 155 First, the Gray exception does not require compensation for damage inflicted in the proper exercise of the police

149. Dickgieser v. State, 105 P.3d 26, 28, 33 (Wash. 2005) (en banc).

150. See Joyce S. Mendlin \& Roger M. Rosen, Obtaining Recovery for Property Damage Through Inverse Condemnation, 33 L.A. LAW. 20, 20 (2011).

151. 122 Cal. Rptr. 2d 38, 49-50 (Ct. App. 2002) (first quoting CAL. ConST. art. I, § 19; and then quoting Breidert v. S. Pac. Co., 394 P.2d 719, 721 n.1 (1964)).

152. Id. at 50 (citing Albers v. County of Los Angeles, 398 P.2d 129, 137 (Cal. 1965)).

153. Id. (quoting Albers, 398 P.2d at 136).

154. Id. (citing Holtz v. Superior Court, 475 P.2d 441, 445 (Cal. 1970)).

155. Id. (citing Albers, 398 P.2d at 136-37). 
power. ${ }^{156}$ Second, the Archer exception does not require an upper riparian proprietor to pay compensation for damages it has a right to inflict under the common enemy doctrine to protect his or her own property. ${ }^{157}$ The California Supreme Court in Belair v. Riverside County Flood Control District balanced the conflicting concerns under the Albers rule of strict liability and the Archer exception in a case involving flood damage that occurred after a levee failed. ${ }^{158}$ The Belair court determined that the Albers rule would discourage needed flood control projects, while the Archer exception would unfairly burden the private landowner, holding:

[W] here the public agency's design, construction or maintenance of a flood control project is shown to have posed an unreasonable risk of harm to the plaintiffs, and such unreasonable design, construction or maintenance constituted a substantial cause of the damages, plaintiffs may recover regardless of the fact that the project's purpose is to contain the "common enemy" of floodwaters. ${ }^{15}$

The Arreola court explained that "[u]nder Belair, the public entity is not immune from suit, but neither is it strictly liable."160 The California Supreme Court later considered six factors, the "Locklin factors," to determine reasonableness in an inverse condemnation action. ${ }^{161}$ After examining California's inverse condemnation law, particularly as to matters involving flood control projects, the Arreola court stated, "[T]he public entity will be liable in inverse condemnation if its design, construction, or maintenance of a public improvement poses an unreasonable risk of harm to the plaintiffs' property, and the unreasonable aspect of the improvement is a substantial cause of damage." $" 162$

The Arreola court applied these rules to the action filed by plaintiffs against Santa Cruz, Monterey County Water Resource Agency, and Monterey for failing to keep the channel clear and causing a levee to fail during the storm. ${ }^{163}$ The court found "that the trial court appropriately assessed the reasonableness of [the Counties' long-standing policy of

156. Albers, 398 P.2d at 136-37 (citing Gray v. Reclamation Dist. No. 1500, 163 P. 1024, 1033 (Cal. 1917)).

157. Id. at 135, 137 (citing Archer v. City of Los Angeles, 119 P.2d 1, 4-5 (Cal. 1941)).

158. 764 P.2d 1070, 1079 (Cal. 1988).

159. Id.

160. Arreola, 122 Cal. Rptr. $2 \mathrm{~d}$ at 51.

161. Id. (citing Locklin v. City of Lafayette, 867 P.2d 724, 750 (Cal. 1994)).

162. Id. (finding unreasonableness should be determined using the Locklin balancing factors).

163. Id. at 44 . 
allowing the Pajaro River Levee Project channel to deteriorate] according to the factors set forth in Locklin," 164 and affirmed that the defendants were "liable in tort and inverse condemnation for extensive damage caused when the [Project] failed during a heavy rainstorm."165 The State of California was also liable in tort and inverse condemnation for higher flood levels and associated damages from its design and construction of Highway 1, which obstructed the flow of floodwater to the sea, and for the drainage culverts that were insufficient to drain the flood. ${ }^{166}$

Over time, the California Supreme Court developed its approach to inverse condemnation claims for property damages from publicly managed flood control projects under article 1, section 19 of the California Constitution. ${ }^{167}$ The court in Bunch v. Coachella Valley Water District explained the law's development beginning with the historical analysis of inverse condemnation liability based on "traditional tort and property law concepts." 168 As discussed briefly above, the Albers decision "shifted the focus in inverse condemnation cases from the common law to the Constitution." 169

Later, the Locklin decision endorsed and refined the reasonableness standard from the Belair decision by developing balancing principles such that a public entity is liable for the damage caused by its actions only if its conduct is unreasonable and a substantial cause of the damage. ${ }^{170}$ The resulting inverse condemnation rule for public flood control works that cause damage to private property does not require fault or negligence under tort law, but instead "requires a balancing of the public need for flood control against the gravity of harm caused by unnecessary damage to private property." 171

California inverse condemnation law recognizes strict liability, tempered by reasonableness and a balancing of private and public interests for public flood control projects. ${ }^{172}$ It precludes the public or

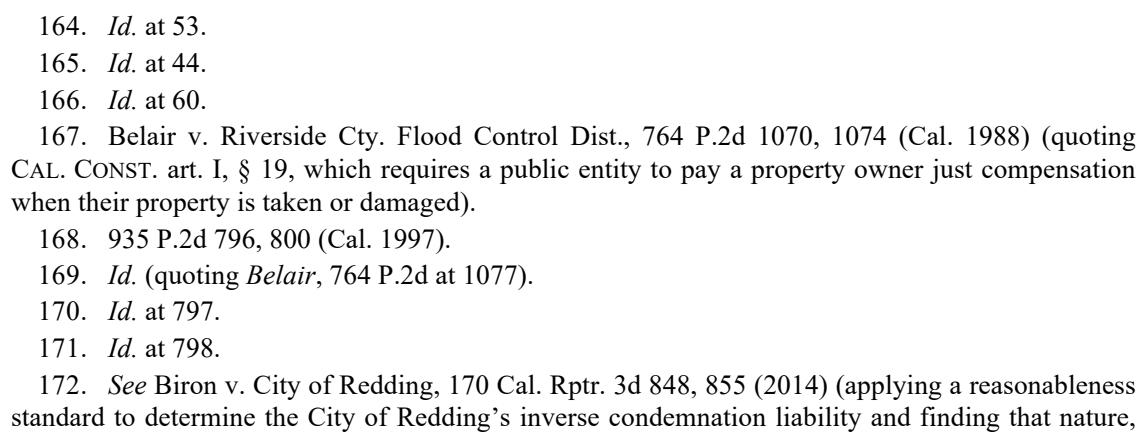


private entity defendant from using traditional tort defenses such as governmental immunity and comparative negligence. ${ }^{173}$ California courts have developed this standard without relying on fault or negligence under tort law, but they require a reasonableness inquiry that appears to resort to nuisance law by balancing the utility of the conduct against the gravity of the harm. ${ }^{174}$ However, in two California cases decided after Bunch, Pacific Bell v. City of San Diego ${ }^{175}$ and Pacific Shores Property Owners Ass'n v. Department of Fish \& Wildlife, ${ }^{176}$ the appellate court did not apply a nuisance-like balancing test and instead relied on strict liability.

In Pacific Bell, a private landowner sued the City of San Diego for tort and inverse condemnation for flooding damages caused by a burst water pipe that was part of the City's firefighting equipment. ${ }^{177}$ Noting that the City was immune under the Tort Claims Act for injuries caused by firefighting equipment, the court made it clear that "the immunities provided by the Tort Claims Act do not insulate a public entity from liability for inverse condemnation." ${ }^{\prime 18}$ The court applied the fundamental policy underlying eminent domain law "that the costs of a public improvement benefiting the community should be spread among those benefited rather than allocated to a single member of the community." 179 This policy echoes the purpose of the Fifth Amendment Takings Clause that is "designed to bar Government from forcing some people alone to bear public burdens which, in all fairness and justice, should be borne by the public as a whole." 180

A subsequent inverse condemnation action decided by the same California appellate district in Pacific Shores applied strict liability to a landowner's claim that a state agency was liable for a physical taking when it intentionally caused flooding. ${ }^{181}$ The agency had assumed control of a local flood control process and provided less flood protection than it previously provided in order to protect the environment. ${ }^{182}$

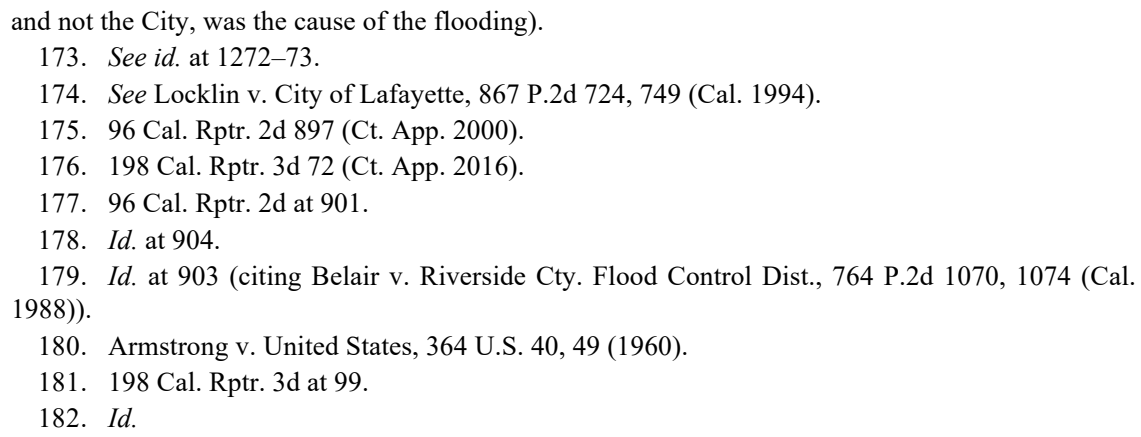


However, not all California courts have allowed inverse condemnation claims when public actions damage private property. In claims alleging property damage from general public works, supplying drinking water, or enforcement action in pursuit of a suspect, the courts have rejected inverse condemnation claims. ${ }^{183}$

It is difficult to discern any particular pattern with inverse condemnation claims in flooding cases as they vary widely among the states. The four major distinctions appear to be:

- Does an inverse condemnation claim require a showing of public use or that the government exercised its eminent domain power? ${ }^{184}$

- Does an inverse condemnation claim require a showing of negligence or nuisance? ${ }^{185}$

- Does an inverse condemnation claim for flooding require recurrent and permanent flooding? ${ }^{186}$

- Does an inverse condemnation claim require a showing of an intentional government action? ${ }^{187}$

\section{c. Takings Liability for Government Inaction?}

In contrast to the federal decisions and some state decisions discussed above, some state courts have held the government liable for

183. See, e.g., City of Oroville v. Superior Court, 446 P.3d 304, 307 (Cal. 2019) (concluding that the City of Oroville was not liable in inverse condemnation for the City's sewer system failure that allowed sewage to back up into a dentist's office building, spewing raw sewage from the toilets, sinks, and drains); Customer Co. v. City of Sacramento, 895 P.2d 900, 901 (Cal. 1995) (refusing to recognize the storeowner's claim for inverse condemnation, even though police caused extensive damage to storeowner's property in pursuit of a suspect); Williams v. Moulton Niguel Water Dist., 232 Cal. Rptr. 3d 356, 366 (Ct. App. 2018) (refusing to find inverse condemnation liability for government actions taken to replace or repair the water or water supply system provided to residents who "voluntarily" accepted water from the water district).

184. Utah requires public use, not negligence to be the basis for action that causes damage, while Washington, North Carolina, and Virginia allow inverse condemnation claims for damage to private property in actions intended either for a public use or not for a public use.

185. Arkansas differentiates tort claims from inverse condemnation claims, but Utah requires injured property owners to present a tort claim if the government is negligent because the public use did not cause the damage. While California does not require fault for inverse condemnation or damagings claims, particularly for wildfire damages, its flooding decisions require a reasonableness inquiry that appears to resort to nuisance law by balancing the utility of the conduct against the gravity of the harm.

186. Illinois requires a showing of intense or radical interference with use and enjoyment of property, Texas requires permanent flooding, and Virginia allows inverse condemnation for damages caused by a single occurrence of flooding.

187. Arkansas and Texas require that inverse condemnation claims based on flooding need to result from intentional government action, while Virginia recognizes that government inaction can support an inverse condemnation claim when there is a duty to act. 
takings caused by government inaction. ${ }^{188}$ For example, in Livingston $v$. Virginia Department of Transportation, the Virginia Supreme Court recognized that government inaction, such as failing to remove accumulated sediment in a relocated water channel, can support an inverse condemnation claim when there is a duty to act. ${ }^{189}$ However, two dissenting justices in Livingston called the inverse condemnation claim based on inaction a "constitutional tort" based on a theory of causation and not an exercise of eminent domain. ${ }^{190}$ Reflecting the tension between identifying damaging government actions as tort or inverse condemnation, the dissent argued:

Boiled down to its essence, Plaintiffs allege that [the Virginia Department of Transportation (VDOT)] had a duty under the law to dredge or otherwise maintain Cameron Run, and its failure to do so caused the flood damage to their properties. This claim is nothing more than a claim for negligence, brought under the guise of the constitutional damaging clause. While it is true that a governmental entity, such as VDOT, may commit acts of negligence in exercising its power of eminent domain, the acts of negligence alone do not constitute a constitutional taking or damaging. It is the exercise of the power of eminent domain that gives rise to a claim of constitutional taking or damaging. In fact, "we have consistently adhered to the view that the eminent domain provisions in the Virginia Constitution have no application to tortious or unlawful conduct."

In Maryland, the Court of Appeals in Litz v. Maryland Department of the Environment followed decisions in Florida and California that held the government liable for taking private property when landowners lost private property by either government inaction or affirmative government action. ${ }^{192}$ The court in Litz held that the government's "failure to act, in the face of an affirmative duty to act," supported an inverse condemnation claim because the city and state knew about a sewage overflow that polluted Litz's campground recreational lake, but did nothing to prevent the contamination. ${ }^{193}$ New Mexico and Arkansas

188. See, e.g., Livingston v. Va. Dep't of Transp., 726 S.E.2d 264, 275 (Va. 2012).

189. Id. ("[T] he government cannot evade liability for a damaging under Article I, Section 11 by simply choosing not to act when it has a duty to do so.").

190. Id. at 277 (McClanahan, J., dissenting) ("[T]here is no cause of action for inverse condemnation without the exercise of [eminent domain] power.").

191. Id. at 279 (McClanahan, J., dissenting) (quoting State Highway \& Transp. Comm'r of Va. v. Lanier Farm, Inc., 357 S.E.2d 531, 534 (Va. 1987)).

192. 131 A.3d 923, 932 (Md. App. 2016) (citing Arreola v. County of Monterey, 122 Cal. Rptr. 2d 38, 55 (Ct. App. 2002); Jordan v. St. Johns County, 63 So.3d 835, 835-39 (Fla. Dist. Ct. App. 2011)).

193. Id. at 931-33. 
have similarly found the government liable for a taking of property when the government intentionally failed to act in light of the foreseeable harm to private property. ${ }^{194}$

Federal, state, and local governments that fail to enforce existing regulations should be subject to takings liability when non-enforcement results in damages to private landowners. ${ }^{195}$ If the Takings Clause was intended to "bar [g]overnment from forcing some people alone to bear public burdens which, in all fairness and justice, should be borne by the public as a whole," 196 isn't the state allocating "property rights when it chooses not to enforce existing property laws" "such as the flood control plan? Holding the government or a private company liable for takings based on inaction when they are responsible for providing service to the public may give public entities an incentive to act affirmatively in the face of public need rather than decline to act for fear of liability. ${ }^{198}$

When state or local governments fail to address sea-level rise through regulation or take adaptive measures to avoid takings liability, they forego the opportunity to protect their communities against inevitable disaster. ${ }^{199}$ However, thus far, attempts to hold the government responsible for failing to respond to known dangers that may impact people and property have been largely unsuccessful.

\section{Wildfires}

Like flooding, wildfires are extremely costly to human life, wildlife, property, and the environment. ${ }^{200}$ Climate change will increase the

194. See Electro-Jet Tool \& Mfg. Co. v. Albuquerque, 845 P.2d 770, 777 (N.M. 1992) (holding that the government must compensate when it foresees the risk of damage to the owner's property or where such risk is so obvious that its incurrence is "the deliberate infliction of harm for the purpose of carrying out the governmental project"); Robinson v. City of Ashdown, 783 S.W.2d 53, 56-57 (Ark. 1990) (upholding a claim against the City of Ashdown for failing to properly pump sewage that ended up in owner's home, explaining that if the government "acts in a manner which substantially diminishes the value of a landowner's land, and its actions are shown to be intentional, it cannot escape its constitutional obligation to compensate for a taking of property on the basis of its immunity from tort action").

195. Timothy M. Mulvaney, Non-Enforcement Takings, 59 B.C. L. REv. 145, 183 (2018).

196. Armstrong v. United States, 364 U.S. 40, 49 (1960).

197. Mulvaney, supra note 195, at 184.

198. See Christopher Serkin, Passive Takings: The State's Affirmative Duty to Protect Property, 113 MICH. L. REV. 345, 347 (2014) (“"F]orcing the government to pay for its regulatory actions but not its omissions will have the perverse effect of deterring the government from doing anything at all, even if a regulatory response could dramatically increase overall societal well-being.").

199. Id. at 348 ("The category of passive takings ... creates an important counterbalance to the threat of traditional takings liability and encourages governments to reduce the overall costs of sealevel rise.").

200. Billion-Dollar Weather and Climate Disasters: Summary Stats, NAT'L OCEANIC \& 
frequency and severity of wildfires and require even greater efforts to suppress, fight, and pay for the aftermath. While federal and state agencies provide the major suppression and firefighting resources, local government, landowners, insurance companies, and the courts must respond to damages incurred in either suppressing fires or recovering after the fires. For example, setting backfires is a firefighting tool that uses an intentionally-set fire to fight an out-of-control wildfire by eliminating a fuel source in the predicted path of the wildfire. ${ }^{201}$ These backfires, while sometimes effective, are risky and may cause substantial damage to property and the environment. ${ }^{202}$

Assigning financial responsibility for the decisions made by the government in fire suppression and firefighting will necessarily impact the alignment of incentives among firefighters and landowners. ${ }^{203}$ As Professor Karen Bradshaw explains:

The government is typically found liable for wildfire damage caused through its actions as a land manager, but is not liable when it acts in its firefighting capacity. This is best illustrated through a series of examples. If the government starts a controlled burn that happens to spread to adjacent privately-owned property, it is liable for the damage caused. In such instances, the government is held liable under the same standards as would apply to a private citizen. If the government acts as a decision-maker, however, rather than in its capacity as a landowner, sovereign immunity applies. Courts afford government firefighting agencies complete, unreviewable discretion to decide how or whether to fight wildfire; private parties may not recover later even if the decisions were shown to be erroneous. ${ }^{204}$

Professor Bradshaw concludes "tort liability provides an insufficient shield against the excessive use of backfire."205

Inverse condemnation or damagings claims offer an alternative to tort liability and align government incentives to act for the public benefit, while also taking into account those individuals and entities who suffer the greatest burdens. Privately held public utilities may also be liable under inverse condemnation or damaging clauses for actions taken that benefit the public. These utilities in turn assert that they cannot spread

\footnotetext{
ATMOSPHERIC ADMIN., https://www.ncdc.noaa.gov/billions/summary-stats [https://perma.cc/5L2EARPT] (last visited Jan. 28, 2020) (estimating economic losses due to wildlife events in 2018 at $\$ 24.5$ billion)

201. Bradshaw, Backfired!, supra note 22, at 159.

202. Id.

203. Id. at $162-64$.

204. Id. at 163 (footnotes omitted).

205. Id. at 164 .
} 
the risk through taxes and face the same insurance policy exclusions for inverse condemnation claims. Southern California Edison and Pacific Gas \& Electric Company (PG\&E) are facing lawsuits from property owners in California whose homes were lost in fires attributed to private utility power lines. ${ }^{206}$

The liability standard for wildfire inverse condemnation claims in California is strict liability, ${ }^{207}$ even though California rejected the strict liability rule in the public flood control context. ${ }^{208}$ In Pacific Bell Telephone Co. v. Southern California Edison Co., the court affirmed the trial court's conclusion that Edison "may be liable as a public entity in inverse condemnation." 209 Pacific Bell sued Edison in inverse condemnation for burn damages to its telephone cables caused by a ground fault from Edison's equipment that sent electricity through Pacific Bell's underground telephone cables. ${ }^{210}$ In addition to its unsuccessful argument that it could not be liable under inverse condemnation as a private entity, Edison argued that the court should apply a reasonableness standard used in inverse condemnation claims arising from flood control projects. ${ }^{211}$ The Pacific Bell court concluded that while the California Supreme Court applies a reasonableness test in the flood control context, "there is no indication from these cases that the Supreme Court intended to replace the strict liability standard in inverse condemnation cases outside the flood control context." 212

California legislators have considered changing the liability standard for inverse condemnation claims against electric utility companies after a wildfire. ${ }^{213}$ The existing liability standard holds utility companies liable for "costs related to a wildfire involving its equipment, even when the

206. See Edvard Pettersson et al., Edison, $P G \& E$ Seek Mercy from Courts Over Doomsday Fire Payouts, BLOOMBERG (Apr. 23, 2018, 4:00 AM), https://www.bloomberg.com/news/articles/201804-23/edison-pg-e-seek-mercy-from-courts-over-doomsday-fire-payouts [https://perma.cc/CB2G$\mathrm{BC} 8 \mathrm{~J}]$.

207. Pac. Bell Tel. Co. v. S. Cal. Edison Co., 146 Cal. Rptr. 3d 568, 574 (Ct. App. 2012).

208. See Biron v. City of Redding, 170 Cal. Rptr. 3d 848 (Ct. App. 2014).

209. 146 Cal. Rptr. 3d 568, 569-70 (Ct. App. 2012). The court agreed with the holding in Barham v. Southern California Edison Co. that no "significant differences exist regarding the operation of publicly versus privately owned electric utilities." Id. at 570, 573 (quoting Barham v. S. Cal. Edison Co., 88 Cal. Rptr. 2d 424, 430 (1999)).

210. Id.

211. Id. at $573-74$.

212. Id. at 575 .

213. John Myers, California Lawmakers Will Abandon Effort to Loosen Wildfire Liability Rules for Utility Companies, L.A. TIMEs (Aug. 18, 2018), https://www.countable.us/articles/7619-losangeles-times-california-lawmakers-abandon-effort-loosen-wildfire-liability-rules-utility-companies [https://perma.cc/B2V2-7CJZ]. 
company followed all existing safety regulations." ${ }^{214}$ In 2018, thenGovernor Jerry Brown proposed giving courts discretion in assessing liability to "'balance the public benefit' of the utility company's services to consumers with the "harm caused to private property." 215 Instead, the legislature enacted Senate Bill 901, signed by Brown on September 21, 2018 , which provided funds of $\$ 1$ billion over five years for fireprotection efforts and regulatory relief to reduce financial exposure for utility companies. ${ }^{216}$ Not surprisingly, a federal study confirmed that the more than 1.8 million acres of California burned by wildfire in 2018 was the highest in California's recorded history and worse than any other state. $^{217}$

In 2019, California again considered efforts to reduce wildfires and save utilities with Governor Gavin Newsom "asking the California Legislature to extend an existing charge on utility customers' bills in hopes of generating $\$ 10.5$ billion for a new wildfire fund, one that power companies could use to pay for fire damage - but only if they meet the state's safety standards." 218 State officials "determined that electrical equipment owned by PG\&E, including power lines and poles, was responsible for at least seventeen of twenty-one major fires in Northern California" in fall of 2017. ${ }^{219}$ PG\&E already faces an estimated potential liability of $\$ 15$ billion from the 2017 wildfires and with a liability insurance policy for $\$ 1.4$ billion that began in August 2018, one of California's biggest utilities filed for bankruptcy following the deadly Camp Fire, which devastated the town of Paradise in November 2018

214. Id.

215. Id.

216. S.B. 901, 2018 Leg., Reg. Sess. (Cal. 2018); see also John Myers, As Climate Change Worsens Wildfires, California will Spend \$1 Billion and Give Utilities New Ways to Shrink Their Fire Expenses, L.A. TIMES (Sept. 21, 2018, 11:20 AM), https://www.latimes.com/politics/la-pol-cawildfire-prevention-law-signed-20180921-story.html] [https://perma.cc/LF3L-L4QR] [hereinafter Myers, Climate Change Worsens Wildfires].

217. Joseph Serna, 2018 Was California's Worst Year of Fire Ever, Federal Report Confirms, L.A. TIMES (Mar. 9, 2019, 3:00 AM), https://www.latimes.com/local/lanow/la-me-ln-californiafires-record-report-20190309-story.html [https://perma.cc/S35M-UH9L]. See generally NAT'L INTERAGENCY COORDINATION CTR., WILDLAND FIRE SUMMARY AND STATISTICS ANNUAL REPORT 2018, at 64-75 (2018), https://www.predictiveservices.nifc.gov/intelligence/2018_statssumm/ annual_report_2018.pdf [https://perma.cc/85D4-JXU9].

218. Taryn Luna, To Reduce Wildfires and Save Utilities, Newsom Wants $\$ 10.5$ Billion from Ratepayers, L.A. TIMES (June 21, 2019, 6:02 PM), https://www.recordnet.com/news/20190621/toreduce-wildfires-and-save-utilities-governor-wants-105b-from-ratepayers [https://perma.cc/2553-QG NZ].

219. Ivan Penn \& Peter Eavis, California Utility Customers May Be on Hook for Billions in Wildfire Damage, N.Y. TIMES (Nov. 14, 2018), https://www.nytimes.com/2018/11/14/business /energy-environment/california-fire-utilities.html [https://perma.cc/L23N-5PXT]. 
and will likely generate another $\$ 15$ billion in claims. ${ }^{220}$ In midNovember 2018, PG\&E's shares dropped 20\%, wiping out "[m]ore than half of its market value ... as the fires have spread." 221

Just one month earlier, in mid-October 2018, PG\&E shut down power to 60,000 customers in Northern California to "reduce wildfire risks from power lines during extreme winds." 222 San Diego Gas \& Electric Company (SDG\&E), which is the primary electric provider for Southern California, also has a power shutoff program to deal with conditions the National Weather Service reports such as "red flag fire warnings, humidity levels, sustained winds, temperature, dry fuel and local terrain." 223 Shutting off power when communities face extreme fire danger conditions may be the only way these utilities can provide public safety during extreme winds. ${ }^{24}$ However, shutting off power to customers also avoids potential liability for damages resulting from what may be the utility's negligence or possible state law violations. ${ }^{225}$ While the safety of people and property from wildfires is paramount, shutting off power to thousands of people may also cause personal injuries and economic damages that could potentially exceed the liability from wildfires and redirect the costs from the utility companies to individuals and businesses.

Nevertheless, failing to shut down power in the face of high winds in high-risk fire areas will subject these utilities to lawsuits when their electrical equipment causes wildfires. In Southern California, plaintiffs are claiming damages against Edison for the Woolsey Fire, which began in Simi Valley, California on November 8, 2018 and burned approximately 98,000 acres to the Malibu coastline. ${ }^{226}$ The blaze was $100 \%$ contained on November 21 after killing three people, "destroying

220. Peter Eavis \& Ivan Penn, California Says PG\&E Power Lines Caused Camp Fire That Killed 85, N.Y. TIMES (May 15, 2019), https://www.nytimes.com/2019/05/15/business/pge-fire.html [https://perma.cc/H5UY-86DA].

221. Penn \& Eavis, supra note 219.

222. Ashley May \& Kristin Lam, PG\&E Keeps Nearly 60,000 Northern California Customers in the Dark to Reduce Wildfire Risk, USA TODAY, https://www.wkyc.com/article/news/nationnow/pge-keeps-nearly-60000-northern-california-customers-in-the-dark-to-reduce-wildfire-risk/46595e6006d-6dc4-45e3-b82e-a0557f7582b3 [https://perma.cc/9E5E-4UNK] (last updated Oct. 15, 2018, 10:00 PM).

223. Id.

224. Id.

225. See Penn \& Eavis, supra note 219 (noting that, in eight cases where downed power lines caused the fall 2017 fires, state officials referred findings to prosecutors).

226. See, e.g., Complaint, Henthorn v. S. Cal. Edison Co., No. 18STCV05569 (Cal. Super. Ct. Nov. 15, 2018), https://images.law.com/contrib/content/uploads/documents/292/35796/WildfiresEdison-complaint.pdf [https://perma.cc/UG9P-X2PM]. 
1,643 structures, and damag[ing] 364 others." ${ }^{, 27}$ The claims alleged include negligence, inverse condemnation, nuisance, trespass, and violations of the Public Utilities Code. ${ }^{228}$ According to the lawsuit, Edison is responsible for the Woolsey Fire, which allegedly started under the same conditions as the 2017 Thomas Fire. ${ }^{229}$ Edison has since "admitted that its equipment was associated with one of the Thomas Fire's ignition points." 230 The suit alleges:

[T] he Woolsey Fire was caused by [Edison]'s negligence in (a) failing to maintain its overhead electrical facilities in a safe manner; (b) failing to perform vegetation management in accordance with applicable regulations and/or (c) failing to shut down the Big Rock $16 \mathrm{kV}$ circuit to prevent a catastrophic wildfire during the Red Flag weather conditions that preceded the Woolsey Fire. ${ }^{231}$

Litigation over wildfires continues to plague California. California courts have denied multiple petitions for review where PG\&E and Edison have argued against imposing inverse condemnation on privately owned utilities when the California Public Utilities Commission (CPUC) declines the utilities' requests to spread liability across ratepayers. ${ }^{232}$ A California appellate court denied review of SDG\&E's challenge to the CPUC's denial of SDG\&E's application to include $\$ 379$ million in ratepayer fees from litigation settlements involving the Witch, Guejito, and Rice Fires in San Diego in 2007. ${ }^{233}$ The CPUC determined that the fires caused by SDG\&E's equipment were the result of SDG\&E's failure to operate as a reasonable and prudent manager. ${ }^{234}$ The appellate court issued its decision to deny the petition for review within days after the

227. See Cause of Woolsey Fire and Agency Response Will Be Focus of LA County Review After Board Vote, L.A. DAILY NEws, https://www.dailynews.com/2018/12/18/cause-of-woolsey-fire-andagency-response-will-be-focus-of-la-county-review-after-board-vote/ [https://perma.cc/BZC3-4K6E] (last updated Dec. 19, 2018 5:22 PM).

228. Complaint, supra note 226, at 17-26.

229. Id. at 4.

230. Megan Diskin, Ventura County Man Sues Edison Alleging Negligence Started the Woolsey Fire, VENTURA COUNTY STAR (Nov. 21, 2018), https://www.vcstar.com/story/news/local/2018/ 11/19/woolsey-fire-ventura-man-southern-california-edison-lawsuit/2057183002/ [https://perma.cc/ 4QPU-Z6XW].

231. See Complaint, supra note 226, at 4.

232. See Petition for Writ of Certiorari at 20-21, San Diego Gas \& Elec. Co. v. Cal. Pub. Utils. Co., 140 S. Ct. 188 (2019) (mem.) (No. 18-1368), 2019 WL 1953402 [hereinafter SDG\&E Petition for Writ of Certiorari].

233. Petition for Review at 19-21, San Diego Gas \& Elec. Co. v. Pub. Utils. Comm'n, No. D074417 (Cal. Ct. App. Nov. 13, 2018), appeal denied, No. S252748, 2019 Cal. LEXIS 710 (Jan. 30, 2019).

234. Id. at 19 . 
deadly 2018 wildfires in early November. ${ }^{235}$ "The Commission's determination that the princip[les] of inverse condemnation did not bar its prudent manager analysis under [Public Utilities Code] section 451 was not in excess of its powers, nor a violation of the law, including the Constitutions of the United States and California."236 The California Supreme Court followed suit and denied review on January 30, 2019. ${ }^{237}$

The petitioners in San Diego Gas \& Electric Co. v. Public Utilities Commission of the State of California then sought review from the U.S. Supreme Court. ${ }^{238}$ SDG\&E alleged that California took property from the private utilities without compensation by imposing strict liability under its inverse condemnation laws without allowing the utilities to recoup these damages from the ratepayers who have benefitted. ${ }^{239}$ In what some are calling "a taking within a taking," the question presented was: "Whether it is an uncompensated taking for public use in violation of the Fifth and Fourteenth Amendments for a State to impose strict liability for inverse condemnation on a privately owned utility without ensuring that the cost of that liability is spread to the benefitted ratepayers." 240 Petitioners contended that while the government or a public utility may pass the costs of inverse condemnation liability on to the ratepayers, a privately owned utility may not raise its rates, unless the CPUC approves. ${ }^{241}$ Instead, the CPUC held SDG\&E to a " "prudent manager' standard that does not apply when the government seeks to spread liability for such costs." 242

Given that the U.S. Supreme Court denied the petition in October 2019, it is unclear when and how this ongoing litigation in California will be resolved. In the meantime, the California legislature and the California Governor have continued to find a path forward in light of the fact that other state utilities may follow PG\&E into bankruptcy if the strict liability standard for inverse condemnation claims remains and other actions are not taken. ${ }^{243}$ Twenty-two mayors in California have

235. Id. at $21-22$.

236. Id. at 22 (alterations in original).

237. San Diego Gas \& Elec. Co., 2019 Cal. LEXIS 710, at*1 (denying petition for review).

238. See 140 S. Ct. 188 (2019) (mem.) (denying writ of certiorari).

239. SDG\&E Petition for Writ of Certiorari, supra note 232, at 1-3.

240. Id. at $\mathrm{i}$.

241. Id. at $13-14$.

242. Id. at 14 (emphasis added).

243. See A.B. 1054, 2019 Leg., Reg. Sess. (Cal. 2019); Taryn Luna, Utility Customers Will Pay $\$ 10.5$ Billion for California Wildfire Costs Under Bill Sent to Newsom, L.A. TIMES (July 11, 2019, 10:42 AM), https:/www.latimes.com/politics/la-pol-ca-wildfire-fund-gavin-newsom-20190711story.html [https://perma.cc/JJB6-FXG4] [hereinafter Luna, Utility Customers Will Pay]. 
even suggested that customers instead of shareholders should operate PG\&E as a publicly-owned cooperative utility. ${ }^{244}$ The municipalization of private utilities has been suggested before in times of electrical blackouts during the Enron scandal ${ }^{245}$ and water shortages during droughts. ${ }^{246}$

In July 2019, California lawmakers approved legislation to "overhaul how the state pays for utility wildfire damage." 247 The legislation created a \$21 billion fund to help utilities pay for wildfire damages with utility shareholders and ratepayers equally splitting the costs. ${ }^{248}$ While this is not a final solution to the issue of increasing occurrence of wildfires in light of climate change, it does buy some time as we focus on wildfire prevention as the ultimate goal. One analyst noted, "shuffling money around can only go so far." ${ }^{249}$ He explained:

Dollars have to come from somewhere.... It's either ratepayers, taxpayers, shareholders, or victims. As these wildfires might pile up, you're going to reach a point of saturation very quickly, where either ratepayers can't pay their bills, shareholders won't buy the stock and on down the line. There's no substitute for doing what we can to prevent wildfires. What a bill like this does is buys a little time. ${ }^{250}$

In November 2019, the bankruptcy court handling PG\&E's case concluded that California's doctrine of inverse condemnation applies to PG\&E and the court predicted that the California Supreme Court would reach the same conclusion. ${ }^{251}$ The debtors in the Chapter 11 case argued that the principle of strict no-fault liability applied to utilities and relied upon by wildfire victims has only been supported by California appellate

244. Justin Ho, California Mayors Want Customers to Run PG\&E, MARKETPLACE (Nov. 5, 2019), https://www.marketplace.org/2019/11/05/california-mayors-public-run-pge/ [https://perma.cc /B3KT-TUCG].

245. See generally Shelley Ross Saxer, Eminent Domain, Municipalization, and the Dormant Commerce Clause, 38 U.C. DAVIS L. REV. 1181 (2005).

246. See, e.g., Golden State Water Co. v. Casitas Mun. Water Dist., 186 Cal. Rptr. 3d 64, 66 (Ct. App. 2015). In Golden State Water Co. v. Casitas Municipal Water District, Ojai residents voted to oust the private utility that supplied water service and replace it with a municipal utility, which planned to use its eminent domain power to acquire the assets of the private company that refused to sell its business. Id.

247. Luna, Utility Companies Will Pay, supra note 243.

248. Robert Walton, California Gov. Newsom to Sign \$21B Wildfire Liability Bill Today, UTIL. DIVE (July 12, 2019), https://www.utilitydive.com/news/california-gov-newsom-to-sign-21bwildfire-liability-bill-today/558630/ [https://perma.cc/CU7D-WJBY].

249. Luna, Utility Customers Will Pay, supra note 243.

250. $I d$.

251. In re PG\&E Corp., No. 19-30088-DM, 2019 WL 6492472, at*1 (Bankr. N.D. Cal. Nov. 27, 2019). 
decisions, which would likely not be upheld by the California Supreme Court. ${ }^{252}$

The bankruptcy court extensively reviewed California law beginning in 1894 and concluded that inverse condemnation applies to private entities providing a public utility service. ${ }^{253}$ The CPUC has authority over rate increases and uses a reasonableness standard based on a "prudent manager" standard to determine whether or not a private utility will be able to spread costs to ratepayers. ${ }^{254}$ The debtors argued that this process "severely prejudices them" because they "are not guaranteed the ability to pass on their inverse condemnation losses by recovery from ratepayers." 255 However, the court noted that no evidence was submitted showing that the debtors were denied cost recovery when they acted prudently. ${ }^{256}$

The PG\&E bankruptcy court decision upheld California's strict liability inverse condemnation doctrine, which allows private utilities to recover costs from ratepayers so long as they act prudently and without tort liability. Shortly after the bankruptcy court's decision, PG\&E settled with wildfire victims in Northern California for $\$ 13.5$ billion. $^{257}$ This settlement included compensation for damages caused by several wildfires including the Butte fire in 2015, the Tubbs fire in 2017, and the Campfire that destroyed Paradise in 2018. ${ }^{258}$ This is PG\&E's third major recent settlement after agreeing to pay $\$ 1$ billion to local governments and other public entities and $\$ 11$ billion to insurance companies that had already paid claims for the 2017 and 2018 wildfires. ${ }^{259}$

Fire-prone states will continue to struggle with deaths, devastation to property and lives, and the economic impact of increasing wildfires. Land use management at the local level will need to prevent and adapt to these continuing disasters. UC Berkeley School of Law's Center for Law, Energy \& the Environment and Resources Legacy Fund prepared recommendations for California's new governor, Gavin Newson, as he "faces the urgent challenge of simultaneously preparing for inevitable disaster, improving the quality of life for residents, and minimizing the

252. $I d$. at $* 5$.

253. $I d$. at $* 2$.

254. Id.

255. Id. at *3.

256. Id.

257. Howard Blume, PG\&E Reaches \$13.5-Billion Settlement with Victims of Devastating California Wildfires, L.A. TIMES (Dec. 6, 2019, 9:44 PM), https://www.latimes.com/california/story/ 2019-12-06/pge-settlement-fire-northern-california [https://perma.cc/YDH7-KF7L].

258. Id. (noting the settlement also included the Ghost Ship fire in Oakland in 2016).

259. Id. 
greenhouse gas emissions of a society of nearly 40 million people." ${ }^{260}$

Specific recommendations of actions that California could take immediately to address the wildfire concerns include: "Creating comprehensive, data-driven maps that identify the highest-risk wildfire areas to help the state target investments in emergency response programs and vegetation treatment; ... [and] creating incentives for local governments to limit development in high-risk fire areas...."261 California's inverse condemnation litigation has generated great interest because of its strict liability standard. Other states, however, have experienced similar claims for wildfire damages, with differing results.

In Colorado, an inverse condemnation claim "requires that the taking itself be accomplished for a public purpose." 262 In American Family Mutual Insurance Co. v. American National Property \& Casualty Co., the Colorado court addressed an insurer's right to subrogation for claims paid to property owners whose land was damaged when a prescribed burn on Denver Water's land "ignited and spread rapidly, resulting in loss of life and significant property damage." ${ }^{263}$ The court found that the prescribed burn protected land from fire destruction by removing dangerous fuels for the public benefit. ${ }^{264}$ Even though "the spreading of the prescribed burn to private property was the direct, natural, or probable result of setting the fire," this finding only addressed whether a taking occurred, not whether it was for a public purpose. ${ }^{265}$ The damage that occurred to the private property "was not part of the prescribed burn's plan" and was not intended as a public benefit. ${ }^{266}$

Similarly, in Texas, an inverse condemnation claim requires that the taking itself be carried out for a public use. ${ }^{267}$ In City of Austin v. Liberty Mutual Insurance, property owners and their insurance companies brought suit against the City of Austin for personal injury and property damage caused by a wildfire which started when the electric utility's

260. Ethan Elkind, Recommendations for Governor-Elect Newsom to Address Wildfire, Water, \& Climate and Transportation Threats, LEGAL PLANET (Dec. 5, 2018), https://legal-planet.org/2018/ $12 / 05 /$ recommendations-for-governor-elect-newsom-to-address-wildfire-water-climate-and-transport ation-threats/ [https://perma.cc/LE4N-N4EL].

261. Id.

262. Am. Family Mut. Ins. Co. v. Am. Nat'1 Prop. \& Cas. Co., 370 P.3d 319, 327 (Colo. App. 2015).

263. Id. at 324 .

264. Id. at 328 .

265. Id. at 328-29.

266. Id. at 328 ("The ensuing wildfire was the precise scenario the controlled burn was ignited to avert.").

267. See City of Austin v. Liberty Mut. Ins., 431 S.W.3d 817 (Tex. App. 2014). 
overhead lines "came in contact with each other during high winds" due to slack in the lines. ${ }^{268}$ The property owners and insurers alleged nuisance, trespass, and inverse condemnation. ${ }^{269}$

The Texas Court of Appeals ruled the tort claims were not barred by governmental immunity because they "arise out of the City's performance of proprietary functions" rather than out of governmental functions. ${ }^{270}$ However, the court concluded that the inverse condemnation claims were not valid takings claims. ${ }^{271}$ The insurers and homeowners did not meet the intent requirement because they failed to "allege facts showing that the fire was substantially certain to occur as a result of the City's maintenance decision," and the City could therefore not be charged with knowledge that the "decision was substantially certain to cause the fire." ${ }^{272}$ Secondly, the appellees did not show that the City's maintenance decision regarding the electrical wires was for a public use because "the fact that some property ultimately suffered harm as a result of the City's power-transmission activities undertaken for the benefit of the public does not mean that the property was damaged in order to effectuate that public benefit." 273 The public use at issue was "power transmission" and the damage to the homeowners did not advance that purpose. ${ }^{274}$

The distinction between a tort and a taking claim may be evident, particularly when the litigants present distinctly separate claims. Nevertheless, there may still be crossover issues, particularly in cases where tort defenses, such as the doctrine of necessity, preclude compensation for a takings claim. For example, in a wildfire damages case in Alaska, damaged landowners presented both a tort claim and a state takings claim. ${ }^{275}$ The Alaska Supreme Court in Brewer v. State reversed the lower court's grant of summary judgment in favor of the State on the landowners' takings claim, but affirmed the judgment that Alaska's firefighting activities are immune from tort liability. ${ }^{276}$ The court held that the specific firefighting immunity provided by an Alaska statute does not distinguish between planning and operational activities,

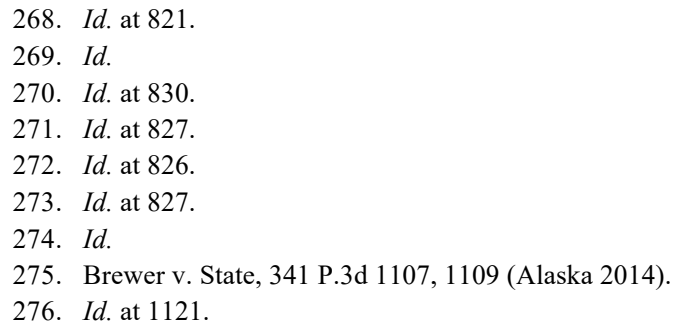


as does the general government immunity statute in determining liability. ${ }^{277}$ The legislature adopted this specific statutory immunity following judicial decisions in which landowners successfully sued Alaska for tort damages based on fire suppression efforts. ${ }^{278}$

The Brewer court allowed the takings claim to proceed, even though the defense of public necessity might render the taking noncompensable if there were an "imminent danger and an actual emergency giving rise to actual necessity." 279 The court agreed with the Federal Circuit decision in TrinCo Investment Co. v. United States (TrinCo II), ${ }^{280}$ that the doctrine of necessity does not automatically preclude compensation for the taking of private property when the government is acting within the scope of its general police power by conducting firefighting activities. ${ }^{281}$ Instead, the doctrine may only be applied to absolve the government of liability when, at the moment of the taking, there was an imminent danger and actual emergency that required the government to choose between damaging private property and averting an impending peril. ${ }^{282}$

The Federal Circuit has also intermingled tort concepts with takings claims. In TrinCo II, the Federal Circuit recognized the tort defense of necessity as a defense to a claim for just compensation resulting from a taking of private property. ${ }^{283}$ TrinCo II involved the destruction of timber from wildfire in a situation where backburning actions by the Forest Service may have resulted in damage to landowners' properties, and there was a material fact issue of whether these actions could be excused based upon the necessity defense. ${ }^{284}$ On remand, the Federal Claims court in TrinCo III relied on a Texas case, Steele v. City of Houston, ${ }^{285}$ and the previously discussed Alaska case, Brewer v. State, ${ }^{286}$ as well as the Federal Circuit's reversal and remand of the takings claims in TrinCo $I I,{ }^{287}$ to establish a "framework for determining when a necessity defense would excuse government-caused fire damage to private property while fighting a wildfire." 288

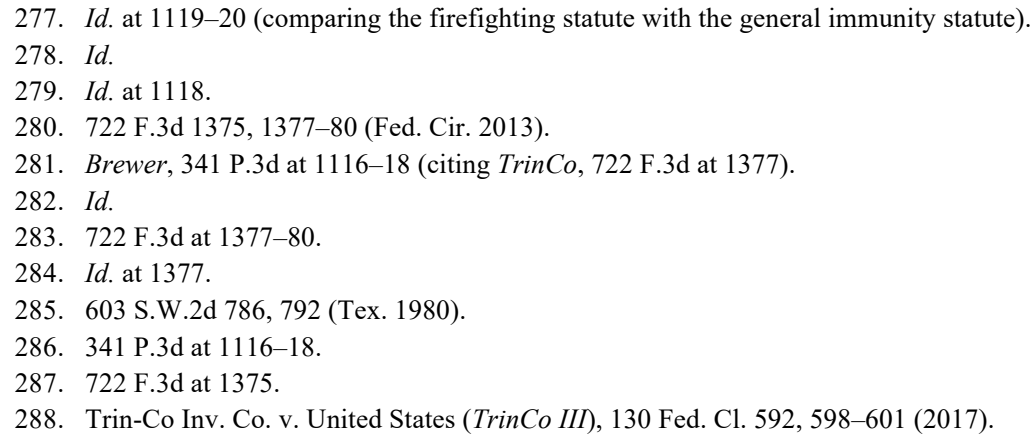


The Federal Circuit in TrinCo II and the Federal Court of Claims in TrinCo III offered scant support for recognizing a necessity defense to a takings claim. The Supreme Court of North Dakota in Irwin v. City of Minot nevertheless relied on the TrinCo II decision to claim that "[f]ederal courts have adopted the 'doctrine of necessity' to absolve the State of compensating a party for lost or damaged property." 289 The Irwin court also relied on the U.S. Supreme Court's decision in Lucas v. South Carolina Coastal Council for "defin[ing] this defense from compensation by requiring proof of actual necessity to forestall 'other grave threats to the lives and property of others." 290 The Irwin court reversed the summary judgment against the City and remanded to allow the City to assert a necessity defense against an inverse condemnation action brought by landowners for damages suffered from the City's removal of clay and topsoil from their property to combat a flood by constructing emergency earthen dikes. ${ }^{291}$

It is not clear how the "doctrine of necessity" can preclude a takings claim under existing takings jurisprudence unless the so-called nuisance exception identified by the Court in Lucas v. South Carolina Coastal Council is summoned to defeat a takings claim. ${ }^{292}$ The nuisance exception from Lucas is based on the premise that the state relied on "background principles of nuisance and property law" to deny a landowner's use of property, such that there is no taking because the landowner never had the right to use the property in a way that constitutes a prohibited nuisance. ${ }^{293}$

The Court recognized this concept in Mugler v. Kansas, upholding a regulation during prohibition that denied a brewery's right to continue operation of what was previously a lawful use. ${ }^{294}$ Similarly, in cases where the government has entered private property to remediate property that poses a safety hazard, courts have denied takings claims. ${ }^{295}$

289. 860 N.W.2d 849,852 (N.D. 2015).

290. Id. at 853 (quoting Lucas v. S.C. Coastal Council, 505 U.S. 1003, 1029 n.16 (1992)).

291. Id. at 853 .

292. See Lucas, 505 U.S. at 1007; Susan S. Kuo, Disaster Tradeoffs: The Doubtful Case for Public Necessity, 54 B.C. L. REV. 127, 127-28 (2013) ("[T]he common law defense of public necessity justifies 'the destruction of real and personal property, in cases of actual necessity, to prevent the spreading of a fire or to forestall other grave threats to the lives and property of others'.... [But] the public necessity defense should not apply to losses occasioned by disaster response." (quoting Lucas, 505 U.S. at 1029 n.16)).

293. Lucas, 505 U.S. at 1030-32.

294. 123 U.S. 623 (1887)

295. Zellmer, supra note 16, at 233 (discussing Hendler v. United States, 36 Fed. Cl. 574 (1996), aff'd, 175 F.3d 1374 (Fed. Cir. 1999); John R. Sand \& Gravel Co. v. United States, 60 Fed. Cl. 230 (2004), rev'd on other grounds, 457 F.3d 1345 (Fed. Cir. 2006); and Hillsboro Partners, LLC v. 
However, when the government acts to address a public nuisance and, in doing so, damages the landowner by cutting off access to their property, a court has allowed a takings claim to proceed. ${ }^{296}$ In addition to using the nuisance exception to counter a takings claim, "[t]he public trust doctrine has provided a viable defense to takings claims by private landowners of riparian and coastal parcels." ${ }^{297}$ This evolving doctrine is particularly relevant to "temporary physical occupations of parcels on navigable waterways and tidelands, which are situated at the geographic core of the public trust doctrine." 298

There appears to be some similarity between the TrinCo line of cases involving wildfires discussed above and the distinction drawn by the Tenth Circuit in the Lech v. Jackson ${ }^{299}$ decision discussed below as to damagings claims from police activities. In the TrinCo line of cases, the tort doctrine of necessity is applied to inverse condemnation claims to avoid the payment of just compensation, ${ }^{300}$ whereas in Lech, the Tenth Circuit distinguished between the police power and the power of eminent domain to avoid a takings claim. ${ }^{301}$ Both lines of cases appear to rely on the early case of Miller $v$. Schoene $e^{302}$ for the proposition that just compensation is not required when the government acts to address emergencies or operates within its police power. ${ }^{303}$

Finally, federal courts have dismissed Fifth Amendment inverse condemnation claims for wildfire damage for failure to state a cognizable claim. In Cary v. United States, landowners in San Diego living nearby the Cleveland National Forest (CNF) suffered damages from the Cedar Fire, which began in the national forest in 2003 when a lost hunter set a signal fire to aid rescuers in their search for him. ${ }^{304}$ Relying on an analogy between the fire and the flooding cases in the Federal Circuit, ${ }^{305}$

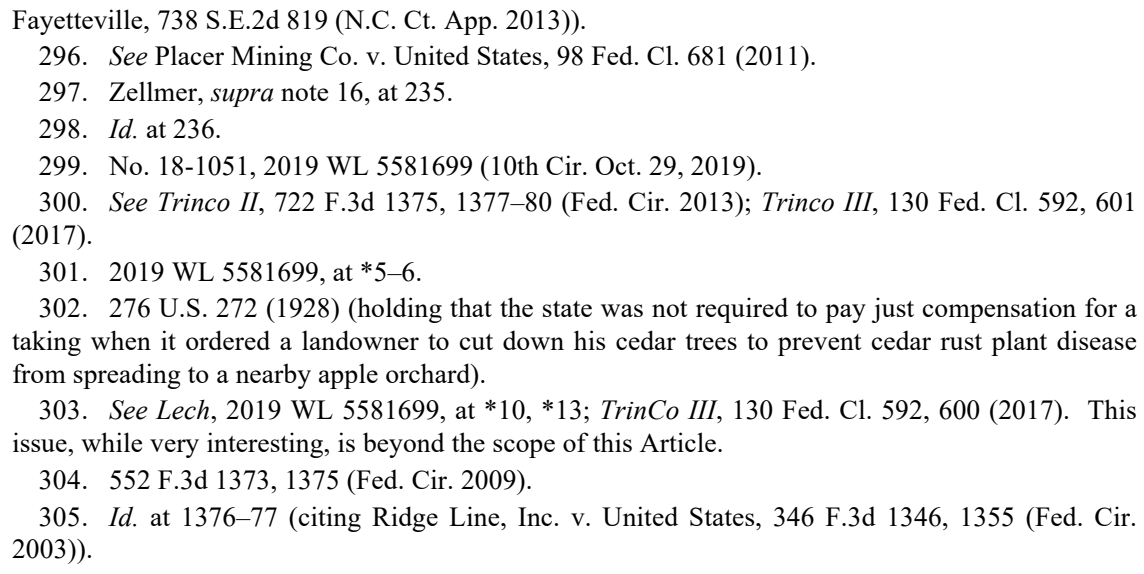


the landowners alleged that the Cedar Fire was "the direct, natural, and probable result" of the two U.S. Forest Service policies - suppressing all forest fires in the CNF and allowing human visitors in the forest. ${ }^{306}$ The landowners compared the Forest Service fire suppression policy, which "disrupts the natural consumption of fuel for the public good," to building a dam, which "disrupt[s] the natural flow of water for the public good." 307 Nevertheless, the court noted, "[t]he key difference between the flood cases and the instant controversy is that the policy of suppressing fires did not set the Cedar Fire in motion as the dams did the floods." 308

The Cary court contrasted fire cases with flood cases. The court explained that in the Ridge Line flooding case, the government "acquired a flowage easement from the runoff created by its alteration of the area's storm drainage." 309 In the Cedar Fire case, however, the government did not acquire any easement or other property through the fire. ${ }^{310}$ The court countered the landowners' contention that the taking by fire was permanent, unlike floodings that recede, by stating:

[M]any a city has rebuilt after a devastating fire, so we cannot infer from the complaint that the fire prevented the rebuilding of infrastructure that would allow the landowners to reoccupy their property. Furthermore, floods and fires can both substantially injure real and personal property with merely one invasion. In the flooding cases, appropriation means that the water stays on the property indefinitely, or predictably returns - a permanent invasion. Here, the fire has come and gone, and there is no allegation that the injuries prevent future use of the land, or that the fire will intermittently but inevitably recur. ${ }^{311}$

\section{Examples of Damagings Claims for Other Unfortunate Events}

The major focus of this Article is to address paying for the disasters from flooding and fires due to human decisions and infrastructure that convert a natural event into a natural disaster. ${ }^{312}$ However, individuals encountering damages to their property caused by government action or

\footnotetext{
306. Id. at 1379 .

307. Id. at 1378

308. Id. at 1378-79 (finding that an incidental or intervening cause such as the hunter's signal fire would not per se preclude government liability if landowners alleged "that the fire that destroyed their property was the direct, natural, and probable result of the forest management policies").

309. Id. at 1380 (citing Ridge Line, 346 F.3d at 1352).

310. Id.

311. Id. at 1381

312. See Pidot, supra note 77 , at 215-16.
} 
inaction in situations other than flood or fire may also experience what they would consider a personal disaster.

This subsection looks at how courts have addressed other types of damages caused by government or private entities acting for the general public benefit but disproportionately burdening certain members of the public. These decisions may be helpful for assessing future inverse condemnation claims and the potential defenses. For example, in the water supply claims discussed below, should there be a different outcome when the actions of public water districts result in "uninvited" water flooding landowners versus "consensual" delivery of water into private plumbing systems? Or, should an inverse condemnation claim be viable for the Flint River situation in Michigan, where the state actors "knew or should have known" of the dangers of the new water source, but not when the Moulton Niguel water district in California added approved chemicals to the water supply that damaged plaintiffs' copper pipes? Are courts continuing to rely on concepts of fault found in tort law even when deciding inverse condemnation claims that generally do not require a showing of negligence?

\section{a. Water Supply}

In Flint, Michigan, the City was under emergency management by officers or employees of the state. ${ }^{313}$ State actors changed the water source for plaintiff residents to the contaminated Flint River and rejected the City's request to return to the Detroit water system once residents realized the new water source was contaminated. ${ }^{314}$ As a result of the state's decision "to send water they knew or had reason to know was unsafe through the pipelines and into plaintiffs' homes and businesses," the plaintiffs "sustained property damage, including irreparably damaged service line pipes, loss of use and enjoyment of their property, and substantial loss in the value of their properties." ${ }^{15}$ The court found this affirmative action to change the water source was a deliberate government action that justified the plaintiffs' claim of inverse condemnation. $^{316}$

Compare the Flint River water case to the California appellate

313. Gulla v. State, No. 340017, 2019 WL 320531, at *3 (Mich. Ct. App. Jan. 24, 2019) (consolidated appeals).

314. Mays v. Snyder, 916 N.W.2d 227, 240 (Mich. Ct. App. 2018), appeal granted sub nom. Mays v. Governor of Michigan, 926 N.W.2d 803 (Mich. 2019).

315. Gulla, 2019 WL 320531, at*6.

316. Id. at $* 18$. 
decision in Williams v. Moulton Niguel Water District, which denied plaintiffs' inverse condemnation claim against the water district for adding chloramines to drinking water for safety purposes because the action did not violate any regulations. ${ }^{317}$ In Moulton Niguel, homeowners alleged that defendant water districts damaged the copper piping in their homes by adding the chemical chloramine to the tap water. ${ }^{318}$ The plaintiffs asserted causes of action for public and private nuisance and for inverse condemnation. ${ }^{319}$ The court held that the water districts were immune from the nuisance claims ${ }^{320}$ and that California's damaging phrase, added to the Constitution in 1879, did not expand eminent domain to cover the voluntary acceptance of water into the plaintiffs' plumbing systems. ${ }^{321}$ The court distinguished this situation where the water districts complied with regulations from an earlier decision in Pacific Bell v. City of San Diego, which upheld an inverse condemnation claim for compensation in a situation where a corroded fire hydrant allowed "uninvited water onto the plaintiff's property." 322 The court found that California's constitutional provision for a taking or damaging of private property for public use "has never been applied to require a public entity to compensate a property owner for alleged property damage" resulting from actions that are "fully compliant" with state and federal regulations. ${ }^{323}$

The Moulton Niguel court recognized the "historically settled application of the Just Compensation Clause ... that government must pay for property it seizes through an exercise of eminent domain." ${ }^{\text {234 }}$ Yet it found that the California constitutional provision for takings and damagings has never "been extended to apply outside the realm of eminent domain or public works." 325 The court compared the homeowners' theory of liability to a "traditional product liability theory." 326 A product liability theory is essentially a strict liability theory to spread the costs for damaged consumers. California courts have

\footnotetext{
317. 232 Cal. Rptr. 3d 356, 357-58 (Ct. App. 2018).

318. Id. at 358 .

319. $I d$.

320. Id. at 361-63.

321. Id. at 364-65.

322. Id. at 366 (citing Pac. Bell v. City of San Diego, 96 Cal. Rptr. 2d 897, 901 (Ct. App. 2000)).

323. Id. at 364 .

324. Id. at 363 (quoting Customer Co. v. City of Sacramento, 859 P.2d 900, 906 (1995) (en banc)).

325. Id. at 366 (quoting Customer Co., 859 P.2d at 906) ("We decline to be the first court to allow such a free-ranging theory of tort liability under the guise of inverse condemnation.").

326. Id.
} 
recognized strict liability for inverse condemnation claims. ${ }^{327}$ The Moulton Niguel court also distinguished previous cases finding inverse condemnation for water damage because those cases involved uninvited water from flooding, whereas here the plaintiffs "voluntarily purchased the water from the $[\mathrm{w}]$ ater [d]istricts and brought the water into their private piping system." 328

Residents in Chicago, Illinois experienced problems with their water supply similar to the situations in Flint, Michigan, and Moulton Niguel, California, when the City of Chicago replaced/repaired its lead pipe water mains and water meters, allegedly causing the release of high levels of lead into the water supply and damaging properties. ${ }^{329}$ Plaintiffs asserted claims of negligence and inverse condemnation. ${ }^{330}$ The court first found that the plaintiffs' negligence claim should not be dismissed because they "ha[d] sufficiently alleged facts to support their claims of injury and damages due to the City's negligence" and the City had not established the affirmative defense of tort immunity. ${ }^{331}$ Second, the court held that the plaintiffs' claim of inverse condemnation should not be dismissed because it "sufficiently allege[d] they ha[d] incurred excess damages beyond that experienced by the public generally" and they did not benefit from the water main replacement because the replacement "made their water more dangerous than that consumed by the general public." 332 Relying on the Illinois Supreme Court's decision in Hampton v. Metropolitan Water Reclamation District, the court noted " "the Illinois takings clause reaches beyond the scope of the federal takings clause' to provide a remedy when government action damages private property." 333

The California court in Moulton Niguel refused to find inverse condemnation liability for government actions taken to replace or repair the water or water supply system provided to residents who "voluntarily" accepted water from the water district. ${ }^{334}$ In contrast, the courts in Flint and Chicago held that even though the water districts were operating within "acceptable" regulatory authority, the government actions

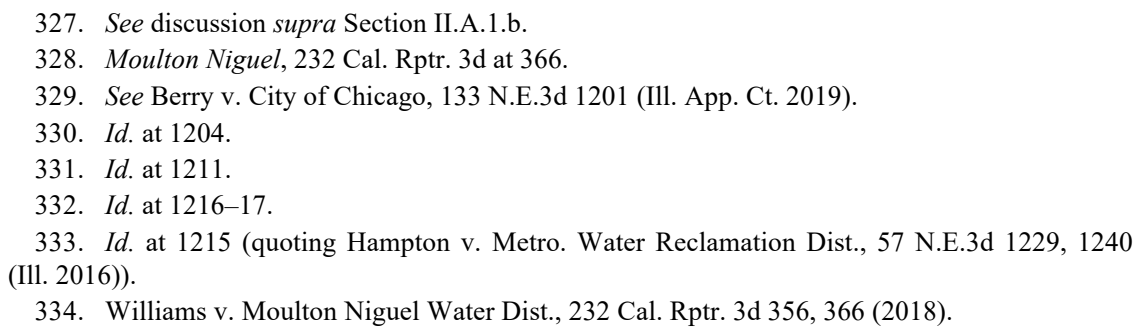


overburdened some of the residents with property damages for the public's benefit. This unfair burdening of some to achieve a public benefit was sufficient to allege a cause of action for inverse condemnation - a concept appropriately applied to prevent some people alone from bearing public burdens, which should be "borne by the public as a whole." 335

\section{b. Public Works}

The intrusion of sewer water from the public sewer system into private residences or businesses has generated continuing litigation across the country, particularly as our infrastructure ages. Several states have held public works liable when a sewer system fails and causes damage to private property, even in situations where there was no direct government action, but instead the government failed to maintain the system.

Missouri courts appear to rely on concepts of negligence and nuisance to find liability under inverse condemnation law. In Christ v. Metropolitan St. Louis Sewer District, homeowners asserted an inverse condemnation claim against Metropolitan St. Louis Sewer District (MSD) for damages they suffered when a blocked main resulted in the backup of contaminated water into their home. ${ }^{336}$ The court explained Missouri "inverse condemnation is the exclusive remedy when private property is damaged by a nuisance operated by an entity having the power of eminent domain." 337 Here, MSD responded after receiving notice of the problem from the plaintiffs and removed the debris causing the blockage, which MSD attributed to storm rainfall and the age of the sewer. ${ }^{338}$ The plaintiffs argued that MSD was liable for failing to maintain and inspect the sewer system, but the court found that "MSD did not commit any affirmative act upon which liability could be based ... [and] MSD cannot be held liable for inverse condemnation for issues based upon an alleged failure to prospectively maintain or inspect the sewers." 339 The court discussed whether the sewer district had a duty to correct a blocked sewer, which indicates its reliance on a negligence standard. $^{340}$ In addition, the court concluded that an inverse

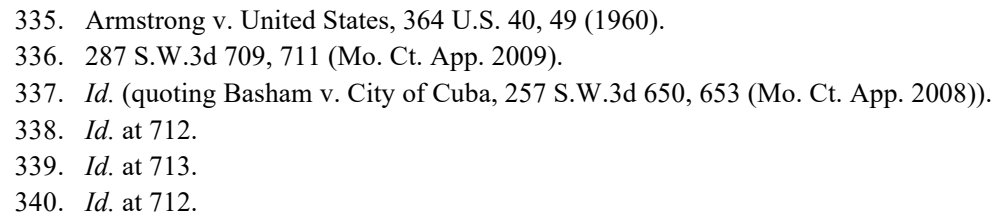


condemnation action in Missouri requires a nuisance that damages private property. ${ }^{341}$

A subsequent Missouri decision, Miller v. City of Wentzville, determined that affirmative action by the City of Wentzville is not required so long as it has notice of a problem and fails to correct or discontinue an unreasonable use that constitutes a nuisance. ${ }^{342}$ In Miller, the plaintiffs alleged that the public street maintained by the City moved and expanded over the years because of the lack of adequate expansion joints. $^{343}$ This "street creep" pushed against the plaintiffs' driveway causing damage to the garage and foundation of their home. ${ }^{344}$ The court determined that once the City had notice of the problem, the plaintiffs were not required to prove that affirmative actions of the government caused the injury. ${ }^{345}$ While the Miller court permitted inaction as the basis for an inverse condemnation claim and the Christ court required affirmative action, nuisance was still required for liability in both of these Missouri decisions. ${ }^{346}$

The Miller court outlined the elements necessary to support an inverse condemnation action based on nuisance, and as in the Christ case, the Miller court used the concept of duty to determine whether the City's lack of action after receiving notice of the problem supported liability under an inverse condemnation claim. ${ }^{347}$ This reliance on duty and a failure to act indicates an analysis based on negligence, but Missouri courts frame liability based on the unreasonableness of a city's inaction. ${ }^{348}$

Other courts have refused to recognize inverse condemnation claims where the government has taken direct action that ultimately damages individual landowners but the government was not aware of the damages its actions would cause. For example, in Dunn v. City of Milwaukie, the Oregon Supreme Court held that the City of Milwaukie's actions in using "highly pressurized water to clean the sewer lines adjacent to plaintiff's house, causing sewage to back up through toilets and bathroom fixtures,"

\footnotetext{
341. Id. at 713 .

342. 371 S.W.3d 54, 61-62 (Mo. Ct. App. 2012).

343. Id. at $55-56$

344. Id.

345. Id. at 61 .

346. See id. at 57; Christ, 287 S.W.3d at 713 .

347. Miller, 371 S.W.3d at 57, 60-61.

348. See id. at 61 (" $[\mathrm{I}] \mathrm{t}$ is the failure to correct or discontinue an unreasonable use after notice that gives rise to a nuisance... The issue then was whether the use was unreasonable, and if so, whether defendant failed to correct or discontinue the unreasonable use.").
} 
did not constitute a taking requiring compensation. ${ }^{349}$ The court explained, "[W]here compensation is sought for injuries caused by physical invasions or occupations of property, the intent element of a takings claim is fundamental in distinguishing between those actions that are the equivalent of an exercise of eminent domain and those that are actionable as ordinary torts." ${ }^{350}$ The court found that because "backups of sewage into adjacent houses due to the [C]ity's hydrocleaning are rare and uncommon occurrences," the evidence was insufficient to support the inverse condemnation claim. ${ }^{351}$ The evidence did not establish "that the sewage backup into plaintiff's house was the necessary, certain, predictable, or inevitable result of the [C]ity's intentional manner of hydrocleaning the adjacent sewer" because these occurrences were rare. ${ }^{352}$

Nebraska takes yet another view as to when property owners are entitled to assert an inverse condemnation claim. It requires that property owners' damages "must be the result of the governmental entity's exercise of its right of eminent domain." 353 In Henderson v. City of Columbus, the Nebraska Supreme Court held that Nebraska's constitutional provision for just compensation "is not a source of compensation for every action or inaction by a governmental entity that causes damage to property. Instead, it provides compensation only for the taking or damaging of property that occurs as the result of an entity's exercise of its right of eminent domain." 354 A Nebraska appellate court in Essink v. City of Gretna relied on the Henderson decision to find that sewage backups into the plaintiffs' residences from the City of Gretna's sewage collection system were not compensable. ${ }^{355}$

Most recently, the California Supreme Court in City of Oroville v. Superior Court concluded that the City of Oroville was not liable in inverse condemnation for the City's sewer system failure that allowed sewage to back up into a dentist's office building, spewing raw sewage

\footnotetext{
349. 328 P.3d 1261, 1263 (Or. 2014).

350. Id. at 1270 .

351. Id. at 1274 .

352. Id. at $1274-75$ (holding plaintiff's negligence action would not be subject to sovereign immunity, but claim was dismissed "for lack of timely notice").

353. Henderson v. City of Columbus, 827 N.W.2d 486, 493 (Neb. 2013).

354. Id. at 494 (applying reasoning from Chavez v. City of Laramie, 389 P.2d 23, 25 (Wyo. 1964)).

355. 901 N.W.2d 466, 475-76 (Neb. Ct. App. 2017) (finding that evidence showed sewer backups were not frequent or recurring and City did not know and could not have foreseen that damage would occur from authorized governmental action).
} 
from the toilets, sinks, and drains. ${ }^{356}$ The court reversed the trial and appellate court decisions finding the City "liable in inverse condemnation where sewage backs up onto private property because of a blockage in the City's sewer main." ${ }^{357}$ Instead, the court required the plaintiffs to show that the injury to property arose from the "inherent dangers of the public improvement as deliberately designed, constructed, or maintained." 358 This requirement avoids a finding of liability in all inverse condemnation cases based solely on the existence of a causal connection between the private property damage and a public improvement. ${ }^{359}$

The California court distinguished the flooding claims addressed in Belair and noted that "Belair did not announce a rule triggering liability in all inverse condemnation cases based solely on the existence of any conceivable causal connection between a public improvement and private property damage." 360 Instead, the court concluded that "inverse condemnation liability depends on whether the property damage was the probable result or necessary effect of an inherent risk associated with the design, construction, or maintenance of the relevant public improvement." 361 Here, the property owners did not sufficiently establish that the damage was substantially caused by the sewage system since the owners failed to install a backwater valve that "would have prevented or substantially diminished the risk of the mishap" that occurred in this case. ${ }^{362}$

Then, a tree falls on your house. In Mercury Casualty Co. v. City of Pasadena, a tree owned by the City of Pasadena fell onto the homeowners' house in hurricane-level winds in 2011.363 The homeowners' insurer sued the City in inverse condemnation, and the trial court found that the tree that fell on the home was a work of public improvement supporting an inverse condemnation claim. ${ }^{364}$ The appellate court reversed, finding that the City was not inversely liable for the damage to the home by the tree because there was no evidence that the City planted it as part of a project to serve a public purpose and the

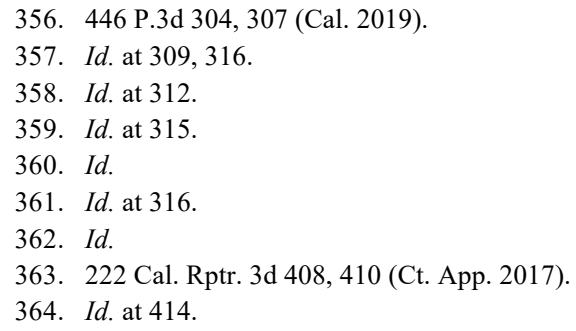


City's tree maintenance plan was not deficient. ${ }^{365}$ The court noted that "[o]nly three published decisions have addressed inverse condemnation claims arising out of a public entity's ownership of trees, none of which held the entity inversely liable." ${ }^{366}$ However, the court pointed out that its holding "does not immunize the City from all forms of liability for damage caused by its trees," because a public entity may be liable for a dangerous condition on public property that damages adjacent private property. ${ }^{367}$

The success of inverse condemnation or damagings claims for public work failures is limited. Courts do not generally hold local governments liable for damages to private property owners caused by falling trees or damages caused by public infrastructure failures. Instead, cities are typically only held liable for landowner damages when the city was aware that its actions could foreseeably cause damage or where it knew that its failure to act would result in property damage.

\section{c. Other Damagings Claims}

Landowners have asserted damagings claims to recover for property damages when law enforcement pursues criminal suspects. ${ }^{368}$ For example, in Wegner v. Milwaukee Mutual Insurance Co., ${ }^{369}$ an armed suspect pursued by the Minneapolis police entered Wegner's home and hid in the front closet. ${ }^{370}$ The SWAT team responded and the tear gas and flash-bang grenades used to apprehend the suspect caused extensive damage to Wegner's house. ${ }^{371}$ Wegner and her insurance company requested just compensation from the City of Milwaukee for the property damage, but the lower courts held that even though there was a "taking" under the Minnesota constitution, the "taking" did not require just compensation because it was a public necessity. ${ }^{372}$ The Minnesota Supreme Court held that where police damage an innocent third party's

\footnotetext{
365. Id. at 419 .

366. Id. at 415 .

367. Id. at 420; see also Rupert v. City of Rapid City, 827 N.W.2d 55, 63 (S.D. 2013) (finding the City of Rapid City liable for inverse condemnation when landowners submitted sufficient evidence to prove that damage to their property and destruction of forty-two trees by the City's use of a deicer were different in kind from damages suffered by general public).

368. See Brady, supra note 73, at 394-95; see also Steele v. City of Houston, 603 S.W.2d 786, 793 (Tex. 1980) (finding landowners were entitled to damages when a city police operation to capture escaped convicts damaged their property).

369. 479 N.W.2d 38 (Minn. 1991).

370. Id. at 39 .

371. Id.

372. Id. at $39-40$.
} 
property while apprehending a suspect, the government is not constitutionally liable for a taking. ${ }^{373}$ The court relied on Steele v. City of Houston, ${ }^{374}$ where fire destroyed plaintiffs' house as the police apprehended a group of prisoners who had taken refuge in the house. ${ }^{375}$ The Texas Supreme Court in Steele remanded the case to the trial court to allow the plaintiffs to prove "that the City of Houston, acting through its officers with authority or color of authority, intentionally set the house on fire ... [and] that the destruction" was for a public use. ${ }^{376}$

Both Washington and California courts have found liability for damagings from wildfires, so it is somewhat surprising that these states have refused to find a taking or damaging where law enforcement activities damage private property. ${ }^{377}$ In Customer Co. v. City of Sacramento, police fired tear gas into a retail store to apprehend a suspect who had taken refuge in the store, which caused extensive damage to the storeowner's property. ${ }^{378}$ The California Supreme Court refused to recognize the storeowner's claim for inverse condemnation. ${ }^{379}$ It noted that the California constitutional provision for paying just compensation for a taking or damaging of private property had "never... been applied to require a public entity to compensate a property owner for property damage resulting from the efforts of law enforcement officers to enforce the criminal laws." ${ }^{380}$

In Eggleston v. Pierce County, the Washington Supreme Court held that the homeowner did not suffer a cognizable takings when her "home was rendered uninhabitable by the execution of a criminal search warrant and preservation order." 381 The court recognized that the Washington takings clause provides greater protection than its Fifth Amendment counterpart, but held that the seizure and preservation of evidence was not a taking under the state constitution. ${ }^{382}$ In addressing the "harder question" of "whether the destruction of property by police activity other than collecting evidence pursuant to a warrant could ever be a

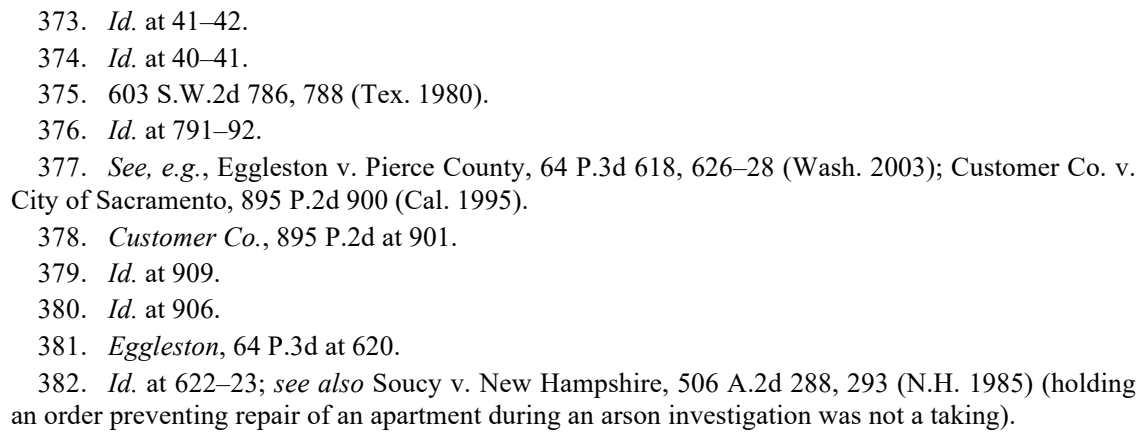


compensable taking," the court refused to extend takings to address situations where law enforcement acts unlawfully because "there are other, more suitable, remedies available." 383

The Tenth Circuit in Lech $v$. Jackson distinguished between government actions taken under the eminent domain power and those actions taken under the police power to find that law enforcement actions do not constitute takings because they are within the scope of the police power. ${ }^{384}$ The Lechs' home was the site of a nineteen-hour standoff between a burglar in their home and the City of Greenwood Village's tactical police team. ${ }^{385}$ As a result of the standoff, the home was uninhabitable, but the City denied liability for the damages. ${ }^{386}$ The Lechs sued alleging a violation of both the federal and the Colorado Takings Clause based on the defendants' failure to provide just compensation for the damaging of their home. ${ }^{387}$

The district court's decision, as upheld by the Tenth Circuit, concluded that "the tactical decisions that ultimately destroyed [the Lechs'] home were made pursuant to the state's police powers and not the power of eminent domain." ${ }^{388}$ While the Tenth Circuit agreed the defendants' actions benefited the public, it cited Mugler v. Kansas, ${ }^{389}$ Miller v. Schoene, ${ }^{390}$ and several other federal circuit decisions distinguishing the police power (which requires no compensation) from the power of eminent domain. ${ }^{391}$

Private owners of taxi medallions have also asserted inverse condemnation claims when local government allows ride sharing apps such as Uber, Lyft, or Gett that devalue the medallions' worth. ${ }^{392}$ Most,

383. Eggleston, 64 P.3d at 625, 627 (suggesting other causes of actions such as constitutional violations under fourth, fifth, or fourteenth amendments to federal or state constitutions, "arbitrary and capricious government action, outrage, trespass, and 42 U.S.C. § 1983").

384. No. 18-1051, 2019 WL 5581699, at *5-6 (10th Cir. Oct. 29, 2019) (noting that if the government's action was authorized by the police power, it is not an exercise of eminent domain power requiring just compensation).

385. Id. at $* 2$.

386. Id.

387. Id.

388. Id. (alteration in original) (quoting Lech v. Jackson, No. 16-CV-01956-PAB-MJW, 2018 WL 10215862, at*10 (D. Colo. Jan. 8, 2018), aff'd, No. 18-1051, 2019 WL 5581699 (10th Cir. Oct. 29, 2019)).

389. 123 U.S. $623,668-69$ (1887).

390. 276 U.S. $272,277,279-80$ (1928).

391. See Lech, 2019 WL 5581699, at*3-6.

392. See, e.g., Progressive Credit Union v. City of New York, 889 F.3d 40, 54-55 (2d Cir. 2018) (dismissing a federal takings claim for lack of ripeness under the second prong of Williamson Cty. Reg'l Planning Comm'n v. Hamilton Bank of Johnson City, 473 U.S. 172 (1985), overruled by Knick v. Township of Scott, 139 S. Ct. 2162 (2019)), overruled by Knick v. Township of Scott, 139 
if not all, of these claims have been unsuccessful. In Newark Cab Ass'n v. City of Newark, taxicab and limousine owners and operators sued the City of Newark for entering into agreements with Uber and other Transportation Network Companies (TNCs). ${ }^{393}$ The plaintiffs alleged that the City violated their rights under the Takings Clause of the Fifth Amendment by subjecting the TNCs to less restrictive regulations than imposed on taxicabs and limousines, thus reducing the value of their property interest in the medallions based on the "inherent value of the exclusivity of the taxi medallion." 394

In dismissing the takings claim, the court first noted that the plaintiffs retained possession of their medallions, and the City thus did not physically take them. ${ }^{395}$ Second, in response to the plaintiffs' allegation that the market value of a taxi medallion fell significantly after Uber began operating in the City, the court held that "the decrease in the market value of the taxi medallions is not sufficient to constitute a cognizable property interest necessary to state a claim under the Takings Clause." 396

At the time of this publication, there appears to be no authority for treating the devaluing of a taxicab medallion as either a federal or state inverse condemnation or damagings claim. ${ }^{397}$ As the Third Circuit noted in Newark Cab, "the plaintiffs have provided no authority in support of their position that their taxi medallions include a right to be the exclusive providers of transportation services in Newark, or that this right constitutes a separate cognizable property interest that can be the subject of a Takings Clause claim." ${ }^{398}$ The Eleventh Circuit in Checker Cab Operators, Inc. v. Miami-Dade County similarly held that the medallions granted by the 1998 Miami-Dade County Ordinance "conveyed only a property interest in providing taxicab services in Miami-Dade Countynot in barring competitors." 399 As did the Third Circuit, the Eleventh

S. Ct. 2162 (2019); Ill. Transp. Trade Ass'n. v. City of Chicago, 839 F.3d 594, 597-98 (7th Cir. 2016) (finding that taxi medallions give owners the right to operate taxicabs, but not the right to exclude competitors offering alternatives); Abramyan v. State, 800 S.E.2d 366, 370 (Ga. 2017) (holding state statutes authorizing and regulating ride sharing were not inverse condemnations of taxi medallions).

393. 901 F.3d 146, 150-51 (3d Cir. 2018).

394. Id. at 152 .

395. Id.

396. Id. at 153 .

397. See, e.g., Checker Cab Phila. v. Phila. Parking Auth., 306 F. Supp. 3d 710, 745 (E.D. Pa. 2018) ("This Court has found no legal precedent in which a medallion-holding taxi company survived a motion to dismiss on a comparable takings theory, much less received a damage award.").

398. Newark Cab Ass'n, 901 F.3d at 154.

399. 899 F.3d 908, 917 (11th Cir. 2018). "The main purpose behind the County's medallion 
Circuit noted that no precedent supported the theory of exclusivity put forth by the medallion holders, and that "[w] hat caselaw we can find overwhelmingly holds that taxicab medallion holders do not have a property right to bar competitors from entering the market." 400

\section{B. Just Compensation as the Payment for Government Damagings}

\section{Is Just Compensation Just?}

The question of "just compensation" continues to be a contentious concept at both the federal and the state level. The U.S. Supreme Court in Kimball Laundry Co. v. United States confirmed that the proper measurement of compensation under the Fifth Amendment is market price, even if the property value includes attributes that are not transferable. ${ }^{401}$ In those situations "where there is no relevant market for the property," courts will generally determine the fair market value "by any method of valuation that is just and equitable." 402 Where the government condemns private property to assemble land for private development, however, fair market value may not be the right standard if "market value has been too difficult to find, or when its application would result in manifest injustice to owner or public."

In the land assembly process, market value may not be difficult to find, but applying the general rule (just compensation "is measured by the property owner's loss rather than the government's gain") to the private owner would be unjust. ${ }^{404}$ Manifest injustice results when the rule precludes the condemnee from sharing any premium realized by a

policy," the court added, "was not to enrich medallion holders, but rather to enhance consumer welfare." Id. at 919.

400. Id. at 920 .

401. 338 U.S. 1, 5-6 (1949).

402. Centr. Valley Gas Storage, LLC v. Southam, 217 Cal. Rptr. 3d 715, 719 (Ct. App. 2017) (quoting Pac. Gas \& Elec. Co. v. Zuckerman, 234 Cal. Rptr. 630, 637 (Ct. App. 1987)) (discussing valuation of natural gas storage leases in a condemnation action when there was no market in California for the leases); see also St. Bernard Port, Harbor \& Terminal Dist. v. Violet Dock Port, Inc., 239 So. 3d 243, 253-55 (La. 2018) (upholding the port's taking of private docking facility but agreeing the property owner was undercompensated because the property was unique and replacement cost was more relevant than fair market value).

403. United States v. Commodities Trading Corp., 339 U.S. 121, 123 (1950). But see Michael DeBow, Unjust Compensation, 46 S.C. L. REV. 579, 581 (1995) ("Although . . the market value approach 'may not be the best measure of value in some cases[,]' the kinds of cases that call for different measures of compensation have been narrowly defined." (quoting United States v. Cors, 337 U.S. 325, 332 (1949))); Glynn S. Lunney, Jr., Compensation for Takings: How Much Is Just?, 42 CATH. U. L. REV. 721, 729-30 (discussing how market value might be an unfair standard, but in practice property owners have not successfully convinced courts to use an alternative standard).

404. Brown v. Legal Found. of Wash., 538 U.S. 216, 235-36 (2003). 
private entity that has benefited directly from the government acquisition. The property owner is not entitled to any "nonpecuniary losses attributable to "his unique need for property or idiosyncratic attachment to it." 405 "Without a change in these general rules, just compensation may not always be just." 406

Many scholars and practitioners have underscored the lack of fairness in the just compensation calculation. ${ }^{407}$ However, there has been limited empirical support for the case against unjust compensation. ${ }^{408}$ Some of the concerns about just compensation include the failure to account for values such as sentimental attachment to the property, moving expenses, the loss of an existing community, ${ }^{409}$ and assimilation into a new community. ${ }^{410}$ In addition, there has been a trend in local and state governments to "sandbag" property owners by obtaining an appraisal of property value and making a pre-condemnation offer based on this appraisal. ${ }^{411}$ If negotiations fail and the government brings an eminent domain proceeding, the government "uses a second, lower

405. Id. at 236 (quoting Kimball Laundry Co., 338 U.S. at 5).

406. David L. Callies \& Shelley Ross Saxer, Is Fair Market Value Just Compensation? An Underlying Issue Surfaced in Kelo, in EMINENT DOMAIN USE AND ABUSE: KELO IN CONTEXT 137, 150 (Dwight H. Merriam \& Mary Massaron Ross eds., 2006); see also Frank I. Michelman, Property, Utility, and Fairness: Comments on the Ethical Foundations of "Just Compensation" Law, 80 HARV. L. REV. 1165, 1210-11 (1967) (discussing demoralization costs to owners when property is condemned); DeBow, supra note 403, at 580 (noting federal law has been criticized but not reformed because of its just compensation definition, which tends to undercompensate); Thomas W. Merrill, Incomplete Compensation for Takings, 11 N.Y.U. ENVTL. L.J. 110, 111 (2002) (discussing how in American law "just compensation means incomplete compensation"); Thomas W. Merrill, The Economics of Public Use, 72 CORNELL L. REV. 61, 82-85 (1986) (proposing to partially modify the basic model of eminent domain to take into account subjective losses and other personal losses); Margaret Jane Radin, Property and Personhood, 34 Stan. L. ReV. 957, 1006 (1982) (explaining how the personhood perspective has sometimes given extra protection to certain property rights even though it has not provided a general limit on eminent domain).

407. See Callies \& Saxer, supra note 406, at 154; see also Brian Angelo Lee, Just Undercompensation: The Idiosyncratic Premium in Eminent Domain, 113 Colum. L. Rev. 593, 594-97 (2013) (disputing the consensus that the fair market value standard undercompensates condemnees and is unfair); Lee Anne Fennell, Just Enough, 113 COLUM. L. REV. SidEBAR 109, 110 (2013) ("[Fair market value] is generally believed to undercompensate.").

408. See Ronit Levine-Schnur \& Gideon Parchomovsky, Is the Government Fiscally Blind? An Empirical Examination of the Effect of the Compensation Requirement on Eminent-Domain Exercises, 45 J. LEGAL STUD. 437, 439, 463 (2016) (examining how compensation rules affect eminent-domain practices); James E. Krier \& Stewart E. Sterk, An Empirical Study of Implicit Takings, 58 WM. \& MARY L. REV. 35, 93-94 (2016) (“[This] study suggests that Supreme Court doctrine has neither inspired nor constrained state lawmakers in any significant fashion ... [and] in some instances state courts have provided less protection than the Court insists they must.").

409. See generally Shai Stern, Takings, Community, and Value: Reforming Takings Law to Fairly Compensate Common Interest Communities, 23 J.L. \& POL'Y 141 (2014).

410. See Fennell, supra note 407, at 111-12.

411. C. Jarrett Dieterle, The Sandbagging Phenomenon: How Governments Lower Eminent Domain Appraisals to Punish Landowners, 17 FEDERALIST SOC’Y REV. 38, 38 (2016). 
appraisal as its evidence of the land's value" at trial. ${ }^{412}$

\section{Compensation for Business Damages}

One of the areas of concern is the compensation paid to "going businesses." In a federal condemnation action, the measure of just compensation is the taker's gain, not the owner's loss, and does not allow for the recovery of business damages. ${ }^{413}$ There are some exceptions allowing for business damages when there is legislation or congressional allowances for lost business damages or when the government intends to take the business itself, such as taking public utilities for purposes of continuing the business. ${ }^{414}$ While the practice "of denying compensation to business owners whose business interests were damaged or destroyed by a condemnation of the underlying land" has been highly criticized, states have made some progress in recognizing these losses as part of just compensation. ${ }^{415}$ Compensating for business losses in state condemnation actions is a question of state law, yet a majority of states still exclude business losses from just compensation recovery. ${ }^{416}$ Even in jurisdictions that allow the recovery of business losses, the damages permitted vary and may be limited in scope and nature. ${ }^{417}$

In a disaster recovery case, the Louisiana Supreme Court decision in South Lafourche Levee District v. Jarreau illustrates how states control the determination of whether or not business damages and attorneys' fees will be part of a just compensation award. ${ }^{418}$ Louisiana amended its constitution and statutes governing compensation for appropriations used

412. Id.

413. Darius W. Dynkowski, Preparing a Business Damage Claim, A.L.I.-A.B.A. Continuing LEGAL EDUC., Jan. 8-10, 2009, at 251, 254 (citing United States v. Powelson, 319 U.S. 266 (1943)). 414. Id. at 254-55.

415. Lynda J. Oswald, Goodwill and Going-Concern Value: Emerging Factors in the Just Compensation Equation, 32 B.C. L. Rev. 283, 283 (1991). See, e.g., L.A. Cty. Metro. Transp. Auth. v. Yum Yum Donut Shops, Inc., 244 Cal. Rptr. 3d 201 (Ct. App. 2019) (holding that under California's good will statute, the donut shop must prove that it deserves damages for loss of goodwill resulting from condemnation and the jury must determine how much it may recover).

416. John C. Murphy et al., What's Wrong with the Law of Valuation in Eminent Domain? Four Rules We Need to Change, A.L.I. ConTINUING LEGAL EDUC., Feb. 5-7, 2015, at 515, 518 ("Eleven states allow for some type of recovery for business losses. But thirty-nine do not.").

417. See Dynkowski, supra note 413, at 253. See, e.g., Thee Aguila, Inc. v. Century Law Grp., LLP, 249 Cal. Rptr. 3d 254, 256-58 (Ct. App. 2019) (finding the state legislatively provided compensation for damages such as "goodwill" of a business operated on condemned property separate from compensation paid for the property, but the lease provision did not distinguish the lessee's leasehold value from goodwill of the business and was not expansive enough to preclude the court from allowing goodwill to exist apart from leasehold).

418. 217 So. 3d 298, 301 (La. 2017). 
in hurricane protection projects following Hurricanes Katrina and Rita. ${ }^{419}$ The court examined these amendments and concluded that they reduced, but did not eliminate, damages paid to property owners for takings or damages to property for hurricane protection projects. ${ }^{420}$ Based on the court's interpretation of the amendments, the landowner was entitled to compensation for the taking or damage to his property "limited to that required by the Fifth Amendment, which is the fair market value of the property at the time of the appropriation, which does not include loss profits and other severance damages." ${ }^{21}$ Relying on the state constitution and legislation, the court upheld the denial of Jarreau's request for compensation for his excavating business and limited his attorneys' fees to "twenty-five percent of the difference between the award and the amount found to be due by the state, the levee board, or the federal government."

\section{Attorneys' Fees Reimbursement}

Similar to business damages discussed above, attorney's fees are not required under federal constitutional demands for just compensation. However, federal legislation, state legislation, or a state constitutional takings provision may require compensation for reasonable attorney's fees. ${ }^{423}$ Section 304(c) of the Uniform Relocation Assistance and Real Property Acquisition Act ("Uniform Relocation Act") waives "federal sovereign immunity as to attorneys' fees and expenses in takings cases." 424 The Uniform Relocation Act allows the court to reimburse a plaintiff "for his reasonable costs, disbursements, and expenses, including reasonable attorney, appraisal, and engineering fees, actually incurred because of such proceeding." $" 425$

Yet even when federal legislation requires that landowners receive "reasonable attorney, appraisal and engineering fees, and other related costs," a state may refuse to pay these costs in a state inverse condemnation claim on a federally assisted project based on state 
statute. ${ }^{426}$ In Long v. South Dakota, the landowners prevailed on their claim for flooding damages caused by highway construction that failed to provide adequate culverts. ${ }^{427}$ However, the South Dakota Supreme Court agreed with the state that the state statute did not expressly authorize attorney fees, but only stated that the state "may provide relocation benefits and assistance... in connection with federally assisted projects to the same extent and for the same purposes as provided for" in the Uniform Relocation Act. ${ }^{428}$

When the state expressly allows reasonable attorney's fees, courts may be reluctant to award such fees. For example, in TransCanada Keystone Pipeline, LP v. Nicholas Family Ltd. Partnership, landowners challenged the proposed pipeline route and succeeded in getting the pipeline company to stay its condemnation petitions during the litigation challenging the constitutionality of such proceedings. ${ }^{429}$ Nebraska law allows for reasonable attorney's fees in a condemnation proceeding, ${ }^{430}$ but in this case, the Nebraska Supreme Court denied the landowners motions for attorney's fees and costs due to a lack of specificity in the landowners' affidavits as to the individual landowner and the work performed. $^{431}$

\section{Who Decides What Remedy Is Just?}

In addition to the issues of whether business damages and attorney's fees will be included as part of just compensation claims, there is still debate over who it is that decides what remedy is just - the Federal Court of Claims or an Article III court with the corresponding Seventh Amendment right to a jury. Professor William Stoebuck's historical exploration of eminent domain noted that, "compensation was the regular

\footnotetext{
426. See Long v. State, 904 N.W.2d 358, 360 (S.D. 2017) (upholding landowners' inverse condemnation claim against the state and the city for damages due to flooding caused by highway construction and inadequate culverts, but denying payment by the state for fees requested).

427. Id.

428. Id. at 363 (alteration in original) (quoting S.D. CoDIFIED LAWs $\S 5-2-18$ (West, Westlaw through 2019 Sess.); see also Rupert v. City of Rapid City, 827 N.W.2d 55, 67 (S.D. 2013) (finding landowners were not entitled to recover attorney fees under the South Dakota statute because the statute did not expressly apply to inverse condemnation cases).

429. 908 N.W.2d 60 (Neb. 2018).

430. NeB. Rev. STAT. § 76-726 (2009 \& Supp. 2013); see also MONT. CONST. art. II, § 29 (“In the event of litigation, just compensation shall include necessary expenses of litigation to be awarded by the court when the private property owner prevails."); SDS, Inc. v. State Dep't of Transp. \& Dev., 978 So.2d 1013, 1018 (La. Ct. App. 2008) (holding a state statute provides for award of attorneys' fees and costs in an inverse condemnation action).

431. TransCanada Keystone, 908 N.W.2d at 68.
} 
practice in England and America, as far as we can tell, during the whole colonial period" and that "[a]n owner aggrieved by the 'jury's' estimate could appeal to the county court." 432

Who decides whether just compensation is "just" arose in Brott $v$. United States, ${ }^{433}$ when Michigan landowners filed suit in federal district court seeking just compensation for the taking of their properties for recreational trails. ${ }^{434}$ The landowners asserted that, "to the extent that the Tucker Act and the Little Tucker Act establish that the Court of Federal Claims has exclusive jurisdiction over the landowners' justcompensation claims, those Acts are unconstitutional because they deprive the landowners of review in an Article III Court and by a jury." 435 The Sixth Circuit reviewed the district court decision and agreed "that the Court of Federal Claims is the exclusive forum for the landowners' compensation claims and that it lacked subject matter jurisdiction." 436 The appellate court found that the Fifth Amendment provides for a right to compensation, but not the means to enforce that right. ${ }^{437}$ It explained that Congress established the Court of Claims (modernly the Court of Federal Claims) as an Article I tribunal in 1855, and in 1887, the Tucker Act expanded the Court of Claims' jurisdiction and waived sovereign immunity to allow for just compensation claims against the United States. ${ }^{438}$

The landowners in Brott contended that their rights under the Fifth Amendment for just compensation were "private" rights that were not assignable to a legislative court or an administrative agency. ${ }^{439}$ However, the Sixth Circuit held that the landowners' claims were "'public right' claims that Congress may assign to a non-Article III court for review." 440 The landowners filed a petition for a writ of certiorari presenting the question: "Can the federal government take private property and deny the owner the ability to vindicate his constitutional right to be justly compensated in an Article III Court with trial by jury?" ${ }^{441}$ The Court denied the petition for certiorari without comment,

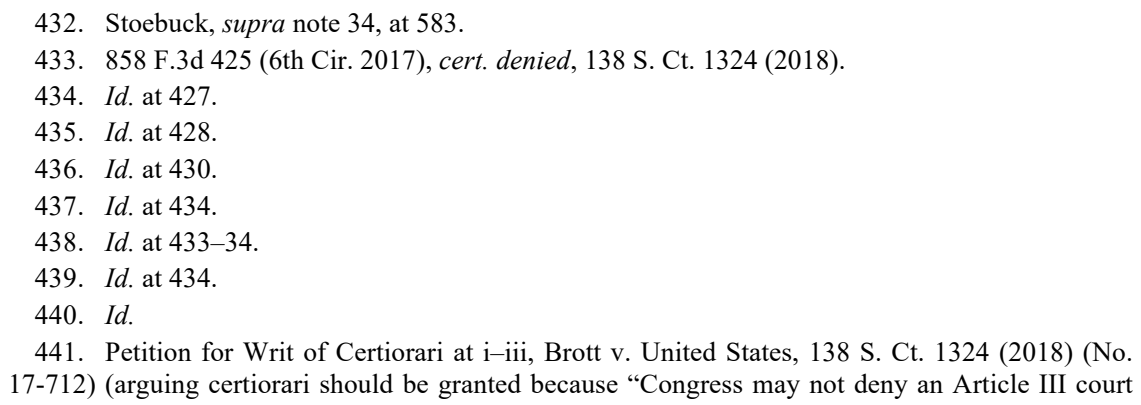


thus, the question remains and future litigation may eventually sort out the final answer as to who decides what constitutes just compensation. ${ }^{442}$

\section{TORT LIABILITY AND INSURANCE}

When government action (and possibly inaction) causes property damage, tort claims will likely be unsuccessful, as sovereign immunity typically shields the government from liability. ${ }^{443}$ State and federal governments may waive immunity in some situations to allow plaintiffs to bring tort claims, but these waivers are limited. ${ }^{444}$ The federal government relies on the Federal Tort Claims Act for immunity for discretionary actions when a federal employee exercises or fails to exercise a "discretionary function or duty... whether or not the discretion involved be abused." 445 The federal government, in turn, "has not only sought to hold individuals and entities liable for the costs of suppressing fires caused by third parties and by seeking astronomical awards, but has also sought to impose criminal liability against those fighting the fires." ${ }^{446}$ State legislation may also shield state and local governments from tort liability. ${ }^{447}$ As discussed above, "those states with 'damaging' clauses attached to their 'takings clauses' allow for greater government liability outside the context of strict tort theory." 448

The line between tort law and takings law is unclear when courts hold that government actions severely impacting the use and enjoyment of land constitute takings yet they invoke a nuisance standard suggesting

jurisdiction to adjudicate an owner's constitutional right to be justly compensated" and "Congress cannot deny by statute the Seventh Amendment's guarantee of a right to trial by jury").

442. See Brott, 138 S. Ct. at 1325.

443. See, e.g., Lorman v. City of Rutland, 193 A.3d 1174, 1183 (finding the City of Rutland's decisions as to its sewer system and whether to replace damaged pipes rather than the entire system were shielded from liability, and the City's decisions were immune from negligence liability).

444. James S. Burling \& Luke A. Wake, Takings and Torts: The Role of Intention and Foreseeability in Assessing Takings Damages, A.L.I.-A.B.A. ConTINUING LEGAL EdUC., Feb. 1719, 2011, at 733, 755 .

445. See Charles H. Oldham, Wildfire Liability and the Federal Government: A Double-Edged Sword, 48 ARIZ. ST. L.J. 205, 206-07 (2016) (alteration in original) (quoting 28 U.S.C. § 2680(a) (2018)). "The question of whether the discretionary function exception protects the federal government from liability arising from acts such as controlled burns gone awry has not been clearly answered by the courts." Id. at 207.

446. Id. at 214. See, e.g., Dovenberg v. United States ex rel. U.S. Forest Serv., 407 F. App'x 149, 149-150 (9th Cir. 2010) (holding a landowner's allegations of Forest Service's negligent training and supervision of fire-fighting personnel that damaged his property were barred by Federal Tort Claims Act's “discretionary function exception” (quoting Nurse v. United States, 226 F.3d 996, 1001 (9th Cir. 2000))).

447. Burling \& Wake, supra note 444, at 779-80.

448. Id. at 781 . 
that the takings claim is based upon a tort. ${ }^{449}$ The interrelationships between inverse condemnation law and governmental tort liability have been significant over time. ${ }^{450}$ For example, before California adopted government immunity, "inverse condemnation and the concept of nuisance ... were the two principal judicial tools for affording relief for property injuries arising out of an admittedly 'governmental' function where no statute authorized recovery." 451

Federal, state, and local governments may not defend against inverse condemnation claims by asserting sovereign or governmental immunity because the government is not immune from claims for the protection or enforcement of constitutional rights. ${ }^{452}$ Tort law does not govern these claims and instead, any damage to real property that public improvement proximately causes may be compensable in inverse condemnation without regard to the foreseeability of the injury or the negligence of the public entity, depending upon the jurisdiction. ${ }^{453}$ Tort damages such as personal injury, emotional distress, or punitive damages are not recoverable because the claim is limited to property damages. ${ }^{454}$

Tort law does not govern takings claims for compensation, but we see from the discussion above that tort defenses, such as the doctrine of necessity, may be imported into takings claim litigation. ${ }^{455}$ In addition, some jurisdictions require a finding of negligence or nuisance to support a takings claim. ${ }^{456}$ For example, Texas courts require that plaintiffs asserting a taking under the state constitution prove more than mere negligence on the part of the government and show that the "governmental entity knows that a specific act is causing identifiable harm or knows that the harm is substantially certain to result." 457 Sovereign immunity does not shield the government from a takings claim, but the state's focus on intent in Texas certainly sounds in tort law. Tort law doctrines should not be applied to inverse condemnation

449. Id. at 782 (citing Steven J. Eagle, Regulatory TAKINGS § 2-5(e)(3) (4th ed. 2009)).

450. Arvo Van Alstyne, Statutory Modification of Inverse Condemnation: The Scope of Legislative Power, 19 STAN. L. REV. 727, 738 (1967).

451. Id. at 738-39 (footnotes omitted).

452. See 1 Civil actions Against State and Local Government: Its Divisions, AGENCIES AND OfFiCERS $§ 1: 21$ (Jon L. Craig ed., 2d ed. 1992 \& Supp. 2019).

453. Joyce S. Mendlin \& Roger M. Rosen, Applying the Inverse Condemnation Remedy to Water Damage, L.A. LAW., Apr. 2015, at 14-15 (discussing federal and California constitutional claims for property damage from pipe and sewer system failures).

454. Id. at 14 .

455. See supra notes $226-41$ and accompanying text.

456. See, e.g., Christ v. Metro. St. Louis Sewer Dist., 287 S.W.3d 709, 711 (Mo. Ct. App. 2009).

457. Harris Cty. Flood Control Dist. v. Kerr, 499 S.W.3d 793, 816 (Tex. 2016) (quoting Tarrant Reg'1 Water Dist. v. Gragg, 151 S.W.3d 546, 555 (Tex. 2004)). 
and damages claims. ${ }^{458}$

Climate change litigation based on the state and federal government's failure to act has largely been futile. For example, two minor children sued the State of Oregon in Chernaik v. Brown seeking declaratory relief based on the public-trust doctrine for the state's failure to protect public trust resources, including the atmosphere, water resources, islands, shorelands, coastal areas, wildlife, and fish against carbon dioxide emissions in Oregon. ${ }^{459}$ The appellate court reversed the trial court's initial dismissal of the plaintiffs' amended complaint, and upon remand, the trial court granted the state's motion for summary judgment. ${ }^{460}$ The court reviewed the trial court decision based on the plaintiffs' argument 'that the public-trust doctrine does more than restrain state action. ... [T] he doctrine imposes fiduciary obligations on the state to take affirmative action to prevent substantial impairment to public-trust resources... from the effects of climate change." ${ }^{, 61}$ However, it concluded that granting the state's motion for summary judgment was correct because "the Oregon public-trust doctrine is rooted in the idea that the state is restrained from disposing or allowing uses of public-trust resources that substantially impair the recognized public use of those resources." 462 The court noted that it could find "no source under the Oregon conception of the public-trust doctrine for imposing fiduciary duties on the state to affirmatively act to protect public-trust resources from the effects of climate change." 463

A group of young people, including one of the plaintiffs in the Chernaik state case, also filed suit in federal court in Oregon. The plaintiffs in Juliana $v$. United States alleged that the federal government violated their civil rights to life, liberty, and property under the Fifth Amendment by failing to take action to phase out carbon pollution and by subsidizing the extraction, production, and use of fossil fuels. ${ }^{464}$ Plaintiffs further alleged that the federal defendants had known for more than fifty years "the unusually dangerous risks of harm to human life, liberty, and property that would be caused by continued fossil fuel

\footnotetext{
458. See infra pp. 493-94.

459. 436 P.3d 26, 27-29 (Or. Ct. App. 2019).

460. Id. at $29-30$

461. Id. at 32 .

462. Id. at 35 .

463. Id. at 35-36 (remanding the case to the trial court because it dismissed the case and it instead needed to enter the requisite declaratory judgment).

464. 339 F. Supp. 3d 1062, 1071 (D. Or. 2018), rev'd and remanded, No. 18-36082, 2020 WL 254149 (9th Cir. Jan. 17, 2020).
} 
burning." ${ }^{465}$ The Ninth Circuit found that the plaintiffs had presented substantial evidence that the federal government's promotion of fossil fuel use and its "failure to change existing policy may hasten an environmental apocalypse." 466 However, the court "reluctantly" concluded that "the plaintiffs" impressive case for redress must be presented to the political branches of government" because the relief the plaintiffs requested was not within the court's constitutional power to redress. ${ }^{467}$

When the government faces inverse condemnation or damagings liability, insurance coverage is generally not available. ${ }^{468}$ This lack of insurance may encourage risk-averse local governments to avoid litigation-prone regulation even if the land use regulations or government actions are beneficial. ${ }^{469}$ Municipal insurance policies overwhelmingly exclude coverage for regulatory takings using some version of the following language: "Claims arising out of or in connection with inverse condemnation caused by the construction of a public work or public improvement, land use regulation, land use planning, the principles of eminent domain, or condemnation proceedings by whatever name called . . .."470 While larger cities may be able to spread the risk or selfinsure, smaller cities may be inclined to avoid regulations that risk takings liability. ${ }^{471}$

Private landowners may individually insure against losses from wildfires, but in some cases, they may eventually lose coverage if they live in high-risk areas. ${ }^{472}$ California's state insurance commissioner announced that one month after the November 2018 wildfires insurance claims were already at $\$ 9$ billion and expected to rise. ${ }^{473}$ The insurance industry in California faces several climate change-related risks in

\footnotetext{
465. Id.

466. Juliana, 2020 WL 254149 , at $* 2$ (9th Cir. Jan. 17, 2020).

467. Id.

468. See Christopher Serkin, Insuring Takings Claims, 111 Nw. U. L. REV. 75, 76 (2016).

469. Id. at $78-79$.

470. Id. at 106 (citation omitted).

471. Id. at $79-80$.

472. Becca Habegger, Insurance Companies Drop Coverage for Hundreds of Thousands of Homeowners in High Wildfire-Risk Areas, Report Shows, ABC10 (Aug. 20, 2019, 9:33 PM), https://www.abc10.com/article/news/local/wildfire/insurance-companies-drop-coverage-for-hundred s-of-thousands-of-homeowners-in-high-wildfire-risk-areas-report-shows/103-f029d0a3-ed43-4913-8 500-195d402e3233 [https://perma.cc/46FF-YHPY].

473. Insurance Claims at $\$ 9$ Billion from California Fires, CBS SF (Dec. 12, 2018, 12:58 PM), https://sanfrancisco.cbslocal.com/2018/12/12/california-wildfire-costs-soar-past-2017-records/ [https ://perma.cc/FSC8-HUNY] (quoting Insurance Commissioner Dave Jones: "The devastating wildfires of 2018 were the deadliest and costliest wildfire catastrophes in California's history ....").
} 
California including physical risk (increasing property damage, health risks, and other physical impacts), transition risk (economic move away from carbon-intensive industries may impact an insurers' assets), and liability risk (increased litigation and liability for losses). ${ }^{474}$ A symposium convened by the Center for Law, Energy \& the Environment at UC Berkeley in June 2018 "identified the top risks and opportunities the insurance community and California residents face in a changing climate, as well as key regulatory reforms, new products, and technological and research developments needed to identify and address them." 475

Insurance companies may proactively hire private fire-fighting companies to protect properties after a fire starts and their insured's property is at risk. ${ }^{476}$ These practices typically apply to high-cost property in the wildland-urban interface (WUI) and command higher premiums. ${ }^{477}$ In addition to experiencing higher insurance premiums, some homeowners have reduced their coverage and accepted higher deductibles to continue their insurance. ${ }^{478}$ For example, the California Department of Insurance noted that homeowners in the WUI have faced increasing premiums and nonrenewal of their policies as this trend reflects insurers' rational response to predicted wildfire losses that exceed premiums collected. ${ }^{479}$ While California has a state-sponsored insurance program (FAIR Plan) for homeowners unable to obtain a policy on the open market, not everyone can afford the premiums. ${ }^{480}$

Residents living in high-risk areas in California or other states may eventually find themselves without insurance for wildfires or may need to relocate if they are unable to rebuild after a fire. ${ }^{481}$ In December 2019, California regulators "imposed a one-year moratorium banning insurers from dropping policies for homeowners in wildfire-ravaged areas of the

\footnotetext{
474. See UC Berkeley Law, Insuring California in a Changing Climate: AdaPting the INDUSTRY TO NEW NEEDS, RISKS, AND OPPORTUNITIES 1 (2019), https://www.law.berkeley.edu/wpcontent/uploads/2019/03/Insuring-California-in-a-Changing-Climate-March-2019.pdf [https://perma. cc/TU2K-PMLR].

475. Id.

476 Karen M. Bradshaw, A Modern Overview of Wildfire Law, 21 Fordham EnvTL. L. Rev. 445, 463 (2010) [hereinafter Bradshaw, A Modern Overview].

477. Id. at 464 .

478. Laura Newberry, As California Fire Disasters Worsen, Insurers Are Pulling Out and Stranding Homeowners, L.A. TIMES (Aug. 31, 2018, 5:00 AM), https://www.latimes.com/ local/lanow/la-me-ln-wildfire-homeowners-insurance-20180830-story.html [https://perma.cc/DAT3$4 \mathrm{KCT}]$.

479. Id.

480. Id.

481. Id.
} 
state." ${ }^{82}$ According to the California Insurance Commissioner, the moratorium provides an opportunity for insurers and homeowners to plan for who will deal with future wildfires. ${ }^{483}$ Existing California law protects homeowners who experienced a total loss from wildfire against being dropped by insurers. ${ }^{484}$ The moratorium is based on a California law also enacted in 2019 that extends protection against insurance cancellation to homeowners living in wildfire emergency areas who did not lose their home. ${ }^{485}$ Some have questioned whether homeowners in disaster-prone areas could be precluded from recovering tort damages from public and private entities because they essentially "came to the nuisance." While this is a valid concern, we are entering into a climate crisis that threatens communities not previously considered to be located in disaster-prone areas. Therefore, we need to address the larger question of how we can address paying for these disasters without burdening the unfortunate souls directly impacted.

States may choose to grant state subsidies or extend insurance protection for inverse condemnation or damagings claims so that the threat of takings liability does not result in reduced regulatory action to address important land use and environmental issues. ${ }^{486}$ States may also need to act to prevent the specter of public utilities facing bankruptcy. As discussed above, in rejecting a change to liability standards for inverse condemnation in an earlier version of legislation, California legislators instead agreed to spend $\$ 1$ billion over five years (paid from proceeds of California's cap-and-trade climate program) to improve fire prevention. ${ }^{487}$ In addition, California Senate Bill 901 enhanced the wildfire-mitigation plans required from utilities and allowed utility companies to "shift some fire-related costs to consumers," so long as the company was not negligent. ${ }^{488}$ Professor Michael Wara, a climate researcher, warns that legislators must do more, including looking at existing insurance limitations for utilities and homeowners. ${ }^{489}$

482. Joseph Serna, California Bans Insurers from Dropping Policies in Fire-Ravaged Areas, L.A. TIMES (Dec. 5, 2019, 3:35 PM), https://www.latimes.com/california/story/2019-1205/california-bans-insurers-from-pulling-policies-in-fire-ravaged-areas [https://perma.cc/68WE-DB $\mathrm{AF}]$.

483. Id.

484. Id.

485. Id.

486. Serkin, Insurance Takings Claims, supra note 468, at 137.

487. Myers, Climate Change Worsens Wildfires, supra note 216.

488. Id.

489. John Myers, Brown Weighs Fate of Wildfire Prevention Bills, L.A. TIMES (Sept. 2, 2018), https://www.pressreader.com/usa/los-angeles-times/20180902/281483572257734 [https://perma.cc/ 2AR9-3FRQ]. 
Governments also face liability when insurance companies pay claims to private property owners and then sue in subrogation for government actions. In AGCS Marine Insurance Co. v. Arlington County, two insurers filed an inverse condemnation suit against Arlington County for property damage to a grocery store caused by the malfunction of a county sewer line that allowed raw sewage to flow into the store. ${ }^{490}$ The Virginia Supreme Court concluded that while the original complaint sounded wholly in tort, the allegations stated a viable claim for inverse condemnation. ${ }^{491}$ It "distinguishe[s] an inverse condemnation claim from a mere tort claim alleging negligence, nuisance, trespass, or other common-law theories of recovery," by pointing to the requirement that the damage was caused by "a purposeful act or omission seeking to advance the "public welfare.",492 The original complaint alleged that the County was responsible for property damage for its failure "to properly maintain and operate the sewage treatment plant," but such a claim would sound in tort and sovereign immunity would shield the County. ${ }^{493}$ The court held that the circuit court erred by not allowing the insurers to amend their complaint to state a viable claim for inverse condemnation. ${ }^{494}$

Disaster victims, regardless of what type of disaster has occurred, should "properly fil[e] and document[] insurance claims [a]s a necessary part of rebuilding after a natural disaster." 495 Typical property insurance claims involve a one-loss event where the insurance adjuster responds promptly and partial payment begins the process of recovery. ${ }^{496}$ However, disaster claims may overwhelm insurance carriers resulting in inexperienced adjusters, delayed inspections, and unpaid claims. ${ }^{497}$ Lawyers involved in unpaid claims and delayed response should notify the insurance carrier, document any repairs, and be familiar with their client's policy provisions. ${ }^{498}$ Property owners and their lawyers should also be aware that the Federal Emergency Management Agency (FEMA) might provide assistance with damages not covered by the policy, depending on the natural disaster and available funding. ${ }^{499}$

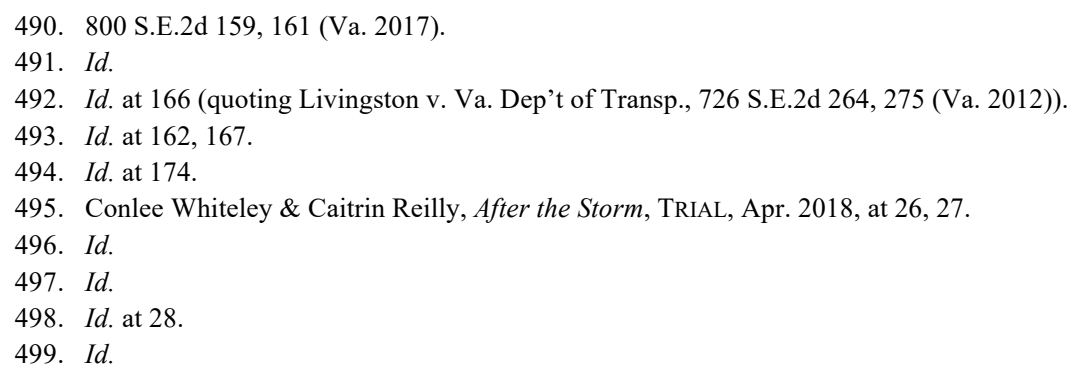


Federal assistance specifically for flood victims may also be available in the form of the National Flood Insurance Program (NFIP). Enacted over fifty years ago as a temporary program to offer federal flood insurance at a low cost and encourage state and local restrictions on floodplain development, the NFIP has instead operated as a "permanent federal subsidy for flood-prone properties along rivers and coastlines abandoned as commercially unviable by the private insurance industry." $" 500$ Some argue that regulatory and physical takings doctrines likely contributed to the NFIP's ineffectiveness because landowners restricted from developing in coastal and floodplain areas sought just compensation from government actions regulating their private property. ${ }^{501}$

Ensuing litigation and the threat of litigation under the Takings Clause may have shifted the cost of development in risky areas from the property owner to the public and deterred local government and communities from regulating to promote coastal and floodplain safety. ${ }^{502}$ While regulatory takings claims have not been as successful as physical takings claims (when flood-control structures release floodwaters onto private property), the confusion between torts and takings may be responsible for the differing results. ${ }^{503}$ The decision as to who should pay for disasters generates a mix of community and individual incentives to develop or not, and to regulate or not, in areas prone to the risk of disasters such as flooding or wildfires. ${ }^{504}$

\section{MitigAtion, EMERGENCY RESPONSE, AND REBUILDING}

Coastal areas, riverbanks, floodplains, aging infrastructure, and properties located in the WUI will continue to be vulnerable to more frequent and intense weather events associated with climate change, rising temperatures, and sea level rise. ${ }^{505}$ Parts II and III explored the

500. Christine A. Klein, The National Flood Insurance Program at Fifty: How the Fifth Amendment Takings Doctrine Skews Federal Flood Policy, 31 Geo. InT'L EnVTL. L. Rev. 285, 287 (2019).

501. Id. at $287-88$.

502. Id. at 286 .

503. See id. at 289.

504. Id. at 315 ("[F]loodplain users may take more risks than they otherwise would if they bore the full costs of their actions, serving as a perverse incentive to lure more people into harm's way."); see also id. at 334-38 (proposing changes to NFIP to eliminate subsidies and require landowners to internalize externalities).

505. U.S. Glob. Change Research Program, 2 Impacts, Risks, and Adaptation IN the United States: Fourth NATIONAL Climate Assessment 71 (2018), https://nca2018.globalchange.gov/downloads/NCA4_Report-in-Brief.pdf [https://perma.cc/VD7T- 
compensation aspect of the disaster cycle. This Part briefly discusses the other strategic processes of the disaster cycle including mitigation, emergency response, and rebuilding. It also summarizes some of the proposals to reduce or prevent the costs from disasters.

\section{A. Mitigation}

\section{Land Use Planning}

Historically, humans have sought to manage water quantity and quality through hydrological alterations such as diverting water for hydropower, agriculture, and urban uses, as well as armoring against drainage water or rising tides by building dikes, floodwalls, levees, dams, and stream channelization. These modifications have eroded riverbanks and shorelines, and destroyed aquatic habitat, fisheries, biodiversity, and ecosystem services provided by floodplains and wetlands. ${ }^{506}$ Not surprisingly given our long-held tradition of "conquering" nature, we call the common law rule allowing landowners to alter the natural flow of water to protect their own property from damage, even if their neighbor suffers, the "common enemy doctrine."

The hydromodification of the Mississippi River Basin to manage floods has taught us three lessons: "1) Rivers will flood; 2) levees will fail; and 3) unwise floodplain development will happen if we let it."508 Levees built after floods in 1927 protected property but also stopped the sand and silt that would have built up the land and kept it above water. The master plan to protect New Orleans with stronger levees, pumps, and gates and restore the coast after Hurricane Katrina in 2005 will exceed $\$ 50$ billion. $^{509}$ Our past approaches to disaster by installing levees, floodgates, pumps, and diversion channels, as well as, restoring breaches, dunes, and marshes may help provide protection against hurricanes, floods, and sea rise, but will unlikely be sufficient to protect our riskiest

\footnotetext{
HKVV] [hereinafter NCA4 REPORT] (analyzing, among other things, "current trends in global change, both human-induced and natural, and project[ing] major trends for the subsequent 25 to 100 years").

506. See Shelley Ross SaXer \& Jonathan Rosenbloom, Social-Ecological Resilience AND SUSTAINABILITY 155-57 (2018).

507. Id. at 155-56.

508. Christine A. Klein \& SANDra B. Zellmer, Mississippi River Tragedies: A Century OF UNNATURAL DISASTER 187-89 (2014).

509. See John Schwartz, How to Save a Sinking Coast? Katrina Created a Laboratory, N.Y. TIMES (Aug. 7, 2015), https://nyti.ms/1T30P91 [https://perma.cc/6TNS-DLTS].
} 
areas. $^{510}$

In the face of rising waters and flooding events, some landowners have appealed to the U.S. Army Corps of Engineers (the Corps) to construct levees in particular locations to maximize the potential development of their land. The Corps has rejected many of these proposals, mostly because the proposed levee locations would interfere with or even destroy valuable wetlands, and courts have upheld the Corps' decisions against landowner challenges. ${ }^{511}$ Communities left outside hurricane levee projects are unprotected by the hard infrastructure of levees and seawalls, but currently "a landowner does not have a takings claim when the government elects not to protect land from the threat of natural hazards." 512 Some have promoted ascribing liability for government inaction, however most major litigation has continued to reject inverse condemnation claims based on inaction as insufficient. ${ }^{513}$

Levees are the main defense against flooding, but they require active maintenance and federal agencies "have taken no action on the remaining key national levee safety-related activities for which they were responsible." ${ }^{14}$ President Obama required greater flood precautions for federal infrastructure in 2015, but days before Hurricane Harvey, President Trump rolled back the Obama order. ${ }^{515}$ The U.S. Department of Housing and Urban Development "reinstated some of the Obama requirements for post-hurricane housing funding, including a directive for them to take 'continued sea level rise' into account." 516 Climate change will "cause substantial losses to infrastructure and property and impede the rate of economic growth." "517 The most recent National Climate Assessment report projects trade and agriculture impacts from

510. SAXER \& ROSENBLOOM, supra note 506, at 162 (noting that areas of highest risk will likely include mostly economically vulnerable residents).

511. See John Lovett, Moving to Higher Ground: Protecting and Relocating Communities in Response to Climate Change, 42 VT. L. REV. 25, 28-30 (2017) (citing Allain-Lebreton Co. v. Dep't of Army, 670 F.2d 43 (5th Cir. 1982)); see also Bayou Des Familles Dev. Corp. v. U.S. Corps of Eng'rs, 541 F. Supp. 1025 (E.D. La. 1982).

512. Lovett, supra note 511, at 30-31.

513. See, e.g., St. Bernard Par. Gov’t v. United States, 887 F.3d 1354 (Fed. Cir. 2018); Harris Cty. Flood Control Dist. v. Kerr, 499 S.W.3d 793 (Tex. 2016). But see Litz v. Md. Dep't of the Env't, 131 A.3d 923 (Md. 2016).

514. U.S. Gov't ACCOUNTABILITY OfFice, GAO-16-709, LEVEe SAFETY: ARMY CORPS AND FEMA Have Made Little Progress in CARrying Out Required Activities 2 (2016), https://www.gao.gov/assets/680/679804.pdf [https://perma.cc/YZ8J-H9RW].

515. Dan Farber, Flood Safety, Infrastructure, and the Feds, Legal Planet (May 28, 2018), https://legal-planet.org/2018/05/28/flood-safety-infrastructure-and-the-feds/ [https://perma.cc/6F4WZSQ5] [hereinafter Farber, Flood Safety].

516. Id.

517. NCA4 REPORT, supra note 505, at 36. 
extreme weather events driven by global warming. ${ }^{518}$ Climate change is a risk to the strength of the U.S. trade position and "[r]ising temperatures, extreme heat, drought, wildfire on rangelands and heavy downpours are expected to increasingly disrupt agricultural productivity in the United States." 519

Land use planning at the local level will be key to reducing the cycle of damage, compensation, and rebuilding in the same risky location. Developing better preventative and response strategies for major disasters such as flooding and wildfires may help reduce the insurance/liability compensation needed to provide for victims damaged by these events. The compensation requirements will necessarily increase as these events escalate with climate change impacts and as communities continue to develop in risk-prone areas. Municipal regulation should address infrastructure and patterns of development to adapt to hazards and reduce the vulnerability of structures to fire risk, flood risk, and other climate-related risks. ${ }^{520}$

Local government's failure to adapt to climate change through appropriate planning and adaptation measures may eventually result in tort liability when there is a duty to adapt under the circumstances. ${ }^{521}$ Adaptation litigation has emerged as a pathway to: "(1) change planning culture, (2) use natural disasters as catalysts for adaptive planning, and (3) navigate more effectively the tensions between public adaptation interests and private property rights." 522 These various mechanisms for recovering the costs of infrastructure changes will be vital as we make the land use changes needed to increase floodplains, cope with drought and wildfires, and manage our coasts for severe storms and rising sea levels.

Local government action in the face of climate change will be needed, not only to adapt to changing conditions and threats, but to aggressively mitigate climate change by reducing local greenhouse gas emissions. ${ }^{523}$ The Intergovernmental Panel on Climate Change suggests we need aggressive mitigation to adapt to climate change because

518. Id. at 13,16 .

519. Id. at 16 .

520. Sarah J. Adams-Schoen, Sink or Swim: In Search of a Model for Coastal City Climate Resilience, 40 COLUM. J. ENVTL. L. 433, 440-41 (2015).

521. Id. at $447-49$ (noting that local governments have yet to face liability for failing to adapt to climate change).

522. Jacqueline Peel \& Hari M. Osofsky, Sue to Adapt?, 99 MinN. L. ReV. 2177, 2184 (2015) (drawing from comparative experiences in Australia to inform U.S. strategies enhancing the role of climate change adaptation).

523. See Adams-Schoen, supra note 520, at 440. 
"reduc[ing] the rate as well as the magnitude of warming... also increases the time available for adaptation to a particular level of climate change." 524 Planning for resilient communities should include both adaptation and mitigation because "effective regulation at the local level cannot be achieved through adaptation alone no matter how robust."

\section{Retreat}

One way to prevent damages in risk-prone areas such as floodplains, coastlines, and wildfire zones is to encourage federal, state, and local governments to "buy out" these properties rather than continue to support the cycle of damage-compensation-rebuild. ${ }^{526}$ Buyouts are getting more expensive as storms and flooding get higher and move inland. ${ }^{527}$ These buyouts are voluntary and when the buyout process takes too long, homeowners are able to obtain taxpayer-subsidized flood insurance policies allowing them to rebuild in the same place. ${ }^{528}$ FEMA's PreDisaster Mitigation Grant Program rose from \$25 million in appropriations in 2015 to $\$ 250$ million in 2019 to provide funding for buyouts and other safeguards such as elevating homes. ${ }^{529}$

Buyout programs were initiated in response to Hurricanes Katrina and Rita on the Gulf Coast, severe flooding in Iowa in 2008, and Superstorm Sandy in 2012. ${ }^{530}$ Professor John Lovett reviewed the efficacy of these three programs and outlined four basic lessons learned from these efforts. First, buyout programs should focus "on a relatively small or tightly clustered community of property owners." 531 Second, the prices offered in a buyout need to be high enough to convince property owners they are being made whole, will be able to relocate successfully to another community, and will receive post-relocation assistance to help

524. Id. (quoting Intergovernmental Panel on Climate Change, Climate Change 2014: IMPACTS, ADAPTION, AND VULNERABILITY: SUMMARY FOR POLICYMAKERS 28 (2014), https://www.ipcc.ch/site/assets/uploads/2018/02/ar5_wgII_spm_en.pdf [https://perma.cc/UVD4-3Y $\mathrm{HD}])$.

525. Id. at 441 .

526. See Cost of Buying Out Flood-Prone Homes: $\$ 5 B$ and Rising, AP NEws (May 27, 2019), https://www.apnews.com/814d62026b13499985a27de09b27c174 [https://perma.cc/B7U3-KN7F].

527. Id.

528. Andrew G. Simpson, Group Says FEMA's Flood Home Buyouts Take Too Long, INS. J. (Sept. 19, 2019), https://www.insurancejournal.com/news/national/2019/09/19/540490.htm [https://perma.cc/9ZY5-J6FX].

529. Id.

530. Lovett, supra note 511, at 34 .

531. Id. at 50 . 
with maintaining community social ties. ${ }^{532}$ Third, buyouts need to recognize and incorporate "the subjective values people have in their homes." "533 Fourth, a successful buyout program must assure property owners "they will regain the social capital of their former community lives." $" 534$

\section{Insurer Incentives}

The economics of protecting homeowners living in high-risk areas from wildfire damage are not necessarily cost effective. ${ }^{535}$ Government firefighting agencies prioritize structure protection resulting in overprotection, since the government pays more to fight fires than the fair market value of the structures protected. ${ }^{536}$ In addition, government regulators may require insurance companies to insure primary residences in high fire areas without pricing the coverage according to the risk. ${ }^{537}$ Finally, because of the availability of federal disaster assistance, insurers do not have the incentive to require homebuilders to use fire safe materials when building in wildland-urban interface areas because homeowners in these risk areas do not fully internalize these risks. ${ }^{538}$

\section{Shutting Down the Electrical Grid or Burying Power Lines}

Shutting down the electrical grid in the face of high winds, red-flag warnings, and drought is an immediate fix to reducing the risk of utilitycaused wildfire. ${ }^{539}$ This is a stop-gap measure as other wildfire solutions such as increased funding, forest-thinning, prescribed burns, stricter building codes, and burying power lines underground will take up to a decade to achieve. ${ }^{540}$ Utility companies have recently used this approach and turned off power to customers during extreme fire danger conditions. In October 2018, PG\&E shut off power to part of Northern California for public safety purposes, leaving almost 60,000 customers without

532. Id.

533. Id. at 51 .

534. Id.

535. Bradshaw, A Modern Overview, supra note 476, at 463-64.

536. Id.

537. Id. at 464 .

538. Id.

539. Michael W. Wara, There's a Quick Way to Help Prevent Wildfires: Shut Off the Power Grid, L.A. TIMES (Dec. 10, 2018, 3:05 AM), https:/www.latimes.com/opinion/op-ed/la-oe-warafighting-wildfire-by-turning-off-the-power-grid-20181210-story.html [https://perma.cc/SX2R-VT $\mathrm{KU}]$.

540. Id. 
power. ${ }^{54}$ The day before the PG\&E shut off, SDG\&E turned off power in Southern California to about 360 customers near Cleveland National Forest. ${ }^{542}$

Not only have utility companies begun using this safety "feature," but in early 2019, a federal judge added new conditions of probation to PG\&E. ${ }^{543}$ The court imposed probation after a jury in 2016 convicted PG\&E on six felony counts arising out of the San Bruno explosion of a gas pipeline. ${ }^{544}$ Following a determination that PG\&E caused eighteen wildfires in 2017, the court imposed three new conditions on PG\&E including this one:

At all times during the 2019 Wildfire Season (and thereafter), PG\&E may supply electricity only through those parts of its electrical grid it has determined to be safe under the wind conditions then prevailing. Conversely, PG\&E must de-energize any part of its grid not yet rated as safe by PG\&E for the wind conditions then prevailing until those conditions have subsided. For example, if Santa Ana winds of up to thirty miles per hour are expected in a given county and if PG\&E has not yet rated those power lines as safe for such winds, then PG\&E must de-energize those lines during the wind event and beforehand notify affected customers that those lines will be de-energized. In determining safety, PG\&E may not take into account the need for reliability of service, the inconvenience to customers resulting from interruption in service, or its impact upon PG\&E's revenues and profits. Reliability is important but safety must come first. Profits are important but safety must come first. Only safe operation will be allowed. $^{545}$

The court in the PG\&E probation order recognized that service interruption would "inconvenience" customers, but did not discuss the substantial cost to customers in terms of loss of productivity, damaged goods, and health and safety considerations when electricity is off. ${ }^{546}$

Comparing such losses to the loss of life from a fire may not be

541. Ashley May \& Kristin Lam, PG\&E Keeps Nearly 60,000 Northern California Customers in the Dark to Reduce Wildfire Risk, USA TODAY (Oct. 15, 2018, 11:35 AM), https: //www.usatoday.com/story/money/nation-now/2018/10/15/pge-voluntarily-shut-off-power-north-cali fornia-wildfires/1646686002/ [https://perma.cc/9LPY-D3ZK].

542. Id.

543. See United States v. Pac. Gas \& Elec. Co., No. CR 14-0175 WHA, 2019 U.S. Dist. LEXIS 36164, at *3 (N.D. Cal. Mar. 5, 2019) (second order to show cause).

544. Id. at *1-3.

545. Pac. Gas \& Elec. Co., No. CR14-0175 WHA, at 3 (Jan. 9, 2019) (first order to show cause), superseded by Pac. Gas \& Elec. Co., 2019 U.S. Dist. LEXIS 36164 (proposing the addition of new probation conditions in light of PG\&E's wildfire mitigation plan and the feedback on the proposed conditions set forth in the January 9 order).

546. See id. 
compelling, but projected losses from power shutdowns should be compared to the cost of burying the power lines that are susceptible to high wind fire risks. In adopting a policy of preemptive shut-offs to reduce wildfire risks, PG\&E joins SDG\&E, which began using this strategy in 2013, and Edison which adopted the strategy in 2017. ${ }^{547}$ In fall 2019, PG\&E shut off power to hundreds of thousands of people in California to prevent electrical equipment from starting wildfires during hazardous weather conditions of winds and low humidity. ${ }^{548}$ Longerterm solutions such as burying power lines underground are expensive and PG\&E management and shareholders may not be willing to undertake the capital expense. ${ }^{549}$ Unfortunately, turning off the power will not prevent all wildfires, which are also be caused by arson, campfires, and lightening, and blackouts will make it more difficult for people to respond for help or evacuate if there is a fire. ${ }^{550}$ Power shutoffs will also have life-threatening consequences for vulnerable groups such as the sick and elderly and will impact others as "people may miss work, their food or medicine may spoil, and heat becomes a concern without air conditioning." 551

\section{B. Response}

The federal government has increased disaster aid programs to direct and implement the federal response to disasters. The "principle statute" is the Robert T. Stafford Disaster Relief and Emergency Assistance Act (Stafford Act), ${ }^{552}$ which coordinates the federal government's response and the system for funneling aid to a particular state after a Presidential declaration of an "emergency" or "major disaster." "553 FEMA administers

547. Alex Wigglesworth \& Joseph Serna, Major Power Shut-Offs Are New Reality as California Enters Peak Wildfire Season, L.A. TIMES (Sept. 24, 2019, 6:52 AM), https://www.latimes.com/ california/story/2019-09-23/red-flag-warnings-get-a-lot-more-perilous-in-california-with-threats-ofmass-power-outages [https://perma.cc/UJX2-ZMV6].

548. Tara Law, California's Power Shutoffs Might Prevent Wildfires. But Are They Worth the Risks?, TIME (Oct. 25, 2019), https://time.com/5710169/california-power-wildfires-pge/ [https://perma.cc/MS2W-P4RD].

549. Id.

550. Id.

551. Id.

552. Robert T. Stafford Disaster Relief and Emergency Assistance Act of 1974, Pub. L. No. 93288, 88 Stat. 143. In 1988, Congress amended the Stafford Act to, inter alia, "provide for more effective assistance in response to major disasters and emergencies." Disaster Relief and Emergency Assistance Amendments, Pub. L. No. 100-707, 102 Stat. 4689 (codified in scattered sections of 42 U.S.C.).

553. Gregory J. Lake, Federal and State Disaster Response - An Introduction, Colo. LaW., Sept. 2012, at 95, 95 . 
the Stafford Act and provides aid such as grants, crisis counseling, disaster unemployment insurance, and housing. ${ }^{554}$ The amount and type of aid provided by the federal government in conjunction with state disaster response will vary over time as the needs of communities change. ${ }^{555}$

Fire suppression costs at the federal level have been over $\$ 1$ billion in thirteen of the last sixteen years, while states collectively spent almost $\$ 2$ billion in 2014. ${ }^{556}$ Although it is not possible to eliminate wildfire vulnerability in areas with abundant fuel such as homes and vegetation, mitigation preparation allows expanded time between fire eruption and its spread into a community and determines whether firefighters focus on evacuation or home protection. ${ }^{557}$ Strategies for community partnerships between agencies and citizens is essential to reduce wildfire vulnerability, particularly in the WUI where wildfire ignitions and large fires have increased due to intensified land use by humans and escalated fire activity due to climate change. ${ }^{558}$ Pre-fire vulnerability reduction such as fire-resistant homes, defensible space, reduction of roadside fuels, and a network of fuels reduction will allow firefighters to combat the fire safely. ${ }^{559}$

Homeowners in the WUI are encouraged to protect their properties proactively by "reducing vegetation near [their] homes or storing firewood away from structures." 560 Nevertheless, many WUI owners do not take these relatively inexpensive measures with the result that some states impose increased liability on these property owners. ${ }^{561}$ As noted earlier in Section II.D regarding insurance, some private insurance companies hire "private firefighting companies to protect properties after a fire starts and a property is at risk, but before the fire reaches the wildland-urban interface property." $" 562$

The public may economically overprotect WUI properties against

554. Id. at 95-96.

555. Id. at 96-97.

556. Michael Rothburn Darling, Note, A Baptism by Incentives: Curing Wildfire Law at the Font of Oil and Gas Regulation, 96 TEX. L. REV. 1235, 1237 (2018).

557. See Crystal A. Kolden \& Carol Henson, A Socio-Ecological Approach to Mitigating Wildfire Vulnerability in the Wildland Urban Interface: A Case Study from the 2017 Thomas Fire, FIRE, Mar. 2019, at 1, 1, 13, https://www.mdpi.com/2571-6255/2/1/9/htm [https://perma.cc/GCH52VD4].

558. Id. at $14-15$.

559. Id. at 12 .

560. Bradshaw, A Modern Overview, supra note 476, at 462.

561. Id.

562. Id. at 463 . 
wildfires by fire suppression efforts and insurance protection for those living in areas with high fire risks. ${ }^{563}$ Public and political pressures on firefighters may force them "to sacrifice control of the wildfire to defend buildings" even if what they are doing is economically wasteful and has no effect on the fire. ${ }^{564}$ In addition, homeowners living in high fire risk areas do not internalize these risks because insurance companies are required "to provide artificially-lowered insurance rates for primary residences in high fire areas." 565

There are also hidden human costs incurred by both the public and the firefighters as the WUI wildfire threats increase. ${ }^{566}$ Developers, with the blessing of community leaders, are building housing developments in forested areas lacking adequate ingress, egress, and water supplies. ${ }^{567}$ These "suicide subdivisions" are ultimately indefensible to wildfires and residents face greater risks of death by being trapped in their homes, while firefighters who rush to the rescue are exposed to heightened risk of wildfire exposure. ${ }^{568}$ Wildfires on public lands are natural occurrences and encourage the renewal of the soil and a new generation of forest as they destroy pests, diseases, and undergrowth. ${ }^{569}$ However, when fires threaten communities in the WUI, federal land managers cannot "simply let these fires play their traditional ecological role of destruction and rejuvenation." 570

We need to develop risk management strategies to deal with the increasing risk of wildfires brought on by climate change. Land use strategies such as managing the WUI, buying out properties in high-risk areas, using building codes, considering liability rules for fires such as making utilities liable, increasing fire insurance costs in WUI property ownership, and becoming more aggressive about removing vegetation will be helpful in mitigating wildfire damages. ${ }^{571}$ In addition, preventive

563. Id

564. Id. at 464 (quoting Randal O'ToOle, The ThOREAu Inst., Reforming the Fire SERVICE: AN ANALYSIS OF FEDERAL FIRE BUdGETS AND INCENTIVES 16 (2002), http://www.ti.org/ firesvc.pdf [https://perma.cc/PX63-PVFE]).

565. Id. (citing Kevin Ramakrishna, Note, Subduing the Ceaseless Storm: Breaking the BuildDestroy-Rebuild Cycle Following Major Catastrophes Through Taxation and Responsibility, 2 ALB. Gov'T L. REV. 328, 335 (2009)).

566. Lloyd Burton, In Dubious Battle: The Human Cost of Wildland Firefighting, 33 J. ENVTL. L. \& LITIG. 87, 88 (2018).

567. Id. at 89 .

568. Id.

569. Id. at 90 .

570. Id. (citing Harold H. Biswell, Prescribed Burning in California Wildlands VEGETATION MANAGEMENT 58-60 (1989)).

571. Dan Farber, Wildfires: Managing the Risks, LEGAL PlANET (Oct. 8, 2018), https://legal- 
precautions such as shut-offs when power lines go down, "[u]ndergrounding wires or replacing wooden poles with steel ones," and using best practices in wildfire prevention will help reduce damages requiring compensation. ${ }^{572}$ With wildfires being part of the "new normal" more work needs to be done on emergency response in terms of evacuation orders, warning systems, fire equipment sharing, and funding. ${ }^{573}$

\section{Rebuilding}

Voters think that there should be limits on building in wildfire zones. ${ }^{574}$ A poll prepared by the UC Berkeley Institute of Governmental Studies for the Los Angeles Times showed that there was "broad backing across party lines, demographic groups and all regions in California for restricting growth in wildfire zones," even though " 1 in 4 Californians live in areas considered at high risk for wildfires." that we should "give governments the tools they need to exercise their existing authority to condemn severe repetitive loss properties and convert them into open space without relying on voluntary-buyout programs." ${ }^{\text {"576 }}$ With flood and wildfire damages, if we do not price insurance according to the actual risk, subsidized government insurance schemes will lead to a cycle of "build-destroy-rebuild.",577 Such programs burden taxpayers and hide the actual risk faced by homeowners, which encourages development in the WUI or in floodplains and coastal areas. ${ }^{578}$

Aging infrastructure is susceptible to climate change as extreme weather and climate-related impacts increase risks or failures of critical systems. ${ }^{579}$ Heavy rain, flooding, heat, wildfires, and other extreme events may disrupt energy and transportation systems, including access

planet.org/2018/10/08/wildfires-managing-the-risks/ [https://perma.cc/C2D8-65P5].

572. Id.

573. Id.

574. Liam Dillon, More Homes in Wildfire Zones? High Number of Californians Say No, Poll Says, L.A. TIMES (June 18, 2019, 5:00 AM), https://www.latimes.com/politics/la-pol-ca-californiawildfire-housing-rules-poll-20190618-story.html [https://perma.cc/Q9ER-YEG7].

575. Id.

576. Alexander S. Mendelson, Note, Taking Away the Tightrope: Fixing the National Flood Insurance Program Circus Via Eminent Domain, 83 BROOK. L. REV. 1519, 1523 (2018).

577. See Bradshaw, A Modern Overview, supra note 476, at 465 (quoting Ramakrishna, supra note 565 , at 329 ).

578. See Mendelson, supra note 576, at 1521.

579. NCA4 REPORT, supra note 505, at $13,118$. 
to roads, bridge stability, and pipeline safety. ${ }^{580}$ "[R]ising temperatures, sea level rise, and changes in extreme events are expected to increasingly disrupt and damage critical infrastructure and property, labor productivity, and the vitality of our communities." "581 Land use practices encourage infrastructure on private properties "designed to meet a predetermined set of criteria or maintain a fixed level of performance established at a single point in time." ${ }^{, 82}$ This "gray infrastructure" in the form of "concrete, metal, pipes, tunnels, [and] tanks" is subject to decay and does not respond or adjust to changes. ${ }^{583}$ "Rapid and intense disturbances, such as hurricanes and floods, and slower-moving ecosystem changes, such as climate change," threaten the resilience of communities. ${ }^{584}$ Resilient infrastructure must be able "to resist, bounce back, adapt, or transform following disturbances."

\section{CONCLUSION}

As climate change increases the severity of droughts, wildfires, flooding, hurricanes, and other extreme weather, ${ }^{586}$ property damages will escalate and individuals, companies, and governments will continue to seek cost reimbursement from others. Ultimately, someone must pay for these increasingly foreseeable costs due to climate change impacts. This Article examined the various ways we are currently paying for disasters and recommends alternatives to the circular litigation approach where damaged property owners file lawsuits against insurers, government, and private actors, who in turn sue others to recover their losses. We can seek to spread these risks by calling on the government to pay inverse condemnation damages or allocate billions of dollars in subsidies and aid through taxation of its citizens. We can also call on utility companies to structure their fees based on the increased risk to those individuals and companies choosing to locate in drought, wildfire, and flood prone areas. Alternatively, we can turn to private market

\footnotetext{
580. Id. at $17,30,96-97$.

581. Id. at 12 .

582. Jonathan Rosenbloom, Fifty Shades of Gray Infrastructure: Land Use and the Failure to Create Resilient Cities, 93 WASH. L. REV. 317, 322 (2018).

583. Id. at 321-22.

584. Id. at $322-23$.

585. Id. at $342-43$ (discussing how relying on technology improves life but also creates new vulnerabilities, such as loss of cellular communication during natural disasters).

586. U.S. Glob. Change Research Program, Climate Change Impacts in the United StATES: The THIRD NATIONAL ClimATE ASSESSMENT 38-40 (2014), http://s3.amazonaws.com/ nca2014/low/NCA3_Full_Report_02_Our_Changing_Climate_LowRes.pdf [https://perma.cc/YWE5 -B7R8].
} 
solutions such as regulatory takings insurance to provide for riskspreading in the face of regulatory action to adapt to climate change risks. ${ }^{587}$

We must all pay for the economic costs of climate change that we cannot avoid through prevention, disaster response, and retreat. Currently, these costs are imposed on those who suffer from extreme weather events and other climate-related harms. ${ }^{588}$ The National Climate Assessment report predicts that the U.S. economy will experience costs of $\$ 500$ billion per year from climate change losses, resulting "in an annual 10 percent reduction in gross domestic product by the end of the century." 589 All of us contribute to climate change, but we do not necessarily pay this hidden climate tax proportionally. ${ }^{590}$ Damages from floods and wildfires are not fairly distributed across our communities, but someone must pay the costs of these events. ${ }^{591}$

California's recent approach for dealing with the wildfire compensation crisis is to extend an existing charge on utility customers' bills for a Department of Water Resources bond established during the California energy crisis in 2000 and scheduled to expire by $2021 .^{592}$ This customer charge would generate $\$ 10.5$ billion through a fifteen-year extension for deposit into a wildfire fund. ${ }^{53}$ SDG\&E, Edison, and PG\&E utilities have the option of contributing a matching $\$ 10.5$ billion in exchange for capping their wildfire liability. ${ }^{594}$ Along with other complex provisions, the utilities will be required to obtain safety certification before using the wildfire fund as a second insurance policy and will only need to pay the funds back if they acted "unreasonably to cause a fire." ${ }^{595}$ Funds like the wildfire fund in California will operate to spread the risk by requiring all ratepayers benefitted by the electrical grid to shoulder the burdens that disasters do not distribute fairly across our communities.

The major focus of this Article was to explore inverse condemnation and damagings claims at the state and federal level as the means to

587. See Serkin, Insurance Takings Claims, supra note 468, at 131.

588. Cary Coglianese \& Mark Nevitt, It's Time to Cut the Hidden Climate Tax, REG. REV. (Feb. 11, 2019), https://www.theregreview.org/2019/02/11/coglianese-nevitt-hidden-climate-tax/ [https:// perma.cc/HSP2-7G4P].

589. Id. (citing NCA4 REPORT, supra note 505, at 1360).

590. Id.

591. Id

592. Luna, Utility Customers Will Pay, supra note 243.

593. Id.

594. Id.

595. Id. 
compensate for disasters. The Fifth Amendment and state inverse condemnation and damagings clauses are designed to distribute fairly the burdens incurred in providing public benefits. In Armstrong v. United States, the U.S. Supreme Court explained that " $[\mathrm{t}]$ he Fifth Amendment's guarantee that private property shall not be taken for a public use without just compensation was designed to bar Government from forcing some people alone to bear public burdens which, in all fairness and justice, should be borne by the public as a whole." ${ }^{, 596}$

As discussed in Part II, many of the states with a state inverse condemnation and damagings provision rely on the Armstrong rationale to support claims that allow private individuals to recover for damages resulting from government or private entity actions for the public benefit. State courts have multiple approaches to resolving claims for flooding and wildfire disasters. In some cases, it is difficult to distinguish between tort and inverse condemnation, while in other cases courts require tort-like conditions such as negligence, reasonableness, nuisance, or fault in explicitly inverse condemnation actions. In the California wildfire cases, inverse condemnation claims do not require fault and a strict liability standard applies. Strict liability in inverse condemnation and damagings is a risk-spreading standard that provides for compensation to those damaged when the government or private entity is acting for the public benefit. This approach is similar to the products liability approach in tort law, which uses strict liability to spread the risk for consumer damage among those companies serving consumers in the marketplace.

If we could take a fresh start in deciding how to compensate victims of disasters using inverse condemnation and damagings claims, I propose that the inverse condemnation and damagings claims found in many state constitutions and statutory provisions observe a "strict liability" standard. I use quotes here because strict liability is a tort standard, and I would argue that inverse condemnation or damagings require just compensation without the need to refer to a tort standard. Regardless of the terminology, such a standard would compensate those people damaged by activities designed to benefit the public as a whole, regardless of the actor's negligence. Approaching takings claims as purely a mechanism for risk spreading would also allow takings claims for government inaction when there is a duty to act for the public benefit.

Tort doctrines such as negligence, nuisance, reasonableness, intent, knowledge, comparative negligence, coming to the nuisance, and 
necessity should not be applicable to the takings analysis, which focuses on equitably spreading the benefits and burdens of acts taken for a public benefit. Although private utilities in California decry the strict liability standard applied by the courts in the wildfire cases, most of the litigation occurs in situations where fault on the part of the utilities has already been established or admitted.

Insurance is also a mechanism for spreading the risk. Therefore, insurers should not be able to seek subrogation from public or private entities that would otherwise be strictly liable to private landowners for inverse condemnation or damaging. Insurers should still be able to subrogate a claim against a private or public entity if the claim is for tort liability such as negligence or nuisance. Insurers must price their policies to incentivize property owners in disaster-prone areas such as the WUI, the floodplains, and the coast, to explore development alternatives, take special precautions in building, and think hard about continuing a cycle of rebuilding after disasters. In certain situations, the government may assist landowners in voluntarily relocating by exercising its eminent domain power to buy-out risky properties.

Finally, public or private entities held liable for disaster damages from flooding or wildfire based on inverse condemnation should be able to pass these costs on to those who have received the benefit of their actions unless the entities have been negligent in fulfilling their duties to the public. Ratepayers and taxpayers will need to bear much of the cost for receiving public benefits. Just as with insurance policy costs, utility rates and taxes should reflect the increased risk of living in disasterprone areas. Paying for disasters in the future will not be easy, but we must face these challenges together and ensure that we are distributing the benefits and burdens of our public needs as equitably as possible. 